NBER WORKING PAPER SERIES

\title{
THE RISE OF DUAL-CLASS STOCK IPOS
}

\author{
Dhruv Aggarwal \\ Ofer Eldar \\ Yael Hochberg \\ Lubomir P. Litov \\ Working Paper 28609 \\ http://www.nber.org/papers/w28609 \\ NATIONAL BUREAU OF ECONOMIC RESEARCH \\ 1050 Massachusetts Avenue \\ Cambridge, MA 02138 \\ March 2021
}

We are grateful to Andrew Metrick, Jay Ritter, Michelle Lowry, Peter Iliev, and Michael Ewens for kindly providing access to their data. We are also grateful to Josh Lerner, Leslie Jeng, and the Private Capital Research Institute for access to the certicates of incorporation data. We thank Yakov Amihud, Bernard Black, Brian Broughman, Jamie Evans, Michael Ewens, Cam Harvey, Jessica Jeffers, Kose John, Stephen Karolyi, Beni Lauterbach, Kate Litvak, Nadya Malenko, William Megginson, Joan-Farre Mensa, Filippo Mezzanotti, Ramana Nanda, Harshit Rajaiya, Adriano Rampini, Abraham Ravid, David Robinson, Bernard Sharfman, Jared Stanfield, Emily Strauss, Deniz Yavuz, and participants at the Colloquium on Law and Economics at Northwestern University, the finance seminar at University of Oklahoma Price College of Business, the Finance brown bag at Duke Fuqua School of Business, the Business Law Workshop at Texas University, the Chicago Entrepreneurship Festival at Northwestern University and University of Chicago, and the annual meetings of the SFS Cavalcade North America, the Midwest Finance Association, and the Venture Capital Section of the American Bar Association for helpful comments and suggestions. We also thank Mandy Chan, Robert Gholson, Tate Johnson, Ali Kayer, SeungWha Lee, Asif Malik, Mayne Thomas, Brody Morgan, Shaoqin Tang, and Peck Yang for research assistance. The views expressed herein are those of the authors and do not necessarily reflect the views of the National Bureau of Economic Research.

NBER working papers are circulated for discussion and comment purposes. They have not been peer-reviewed or been subject to the review by the NBER Board of Directors that accompanies official NBER publications.

(C) 2021 by Dhruv Aggarwal, Ofer Eldar, Yael Hochberg, and Lubomir P. Litov. All rights reserved. Short sections of text, not to exceed two paragraphs, may be quoted without explicit permission provided that full credit, including $\odot$ notice, is given to the source. 
The Rise of Dual-Class Stock IPOs

Dhruv Aggarwal, Ofer Eldar, Yael Hochberg, and Lubomir P. Litov

NBER Working Paper No. 28609

March 2021

JEL No. G24,G28,G34

\section{ABSTRACT}

We create a novel dataset to examine the nature and determinants of dual-class IPOs. We document that dual-class firms have different types of controlling shareholders and wedges between voting and economic rights. We find that the founders' wedge is largest when founders have stronger bargaining power. The increase in founder wedge over time is due to increased willingness by venture capitalists to accommodate founder control and technological shocks that reduced firms' needs for external financing. Greater founder bargaining power is also associated with a lower likelihood of sunset provisions that eliminate dual-class structures within specified periods.

Dhruv Aggarwal

Yale University School of Management

New Haven, CT

dhruv.aggarwal@yale.edu

Ofer Eldar

Duke University

210 Science Drive

Durham, NC 27708

eldar@law.duke.edu
Yael Hochberg

Jones Graduate School of Business

Rice University

6100 Main Street, MS-531

McNair Hall Room 331

Houston, TX 77005

and Massachusetts Institute of Technology

and also NBER

hochberg@rice.edu

Lubomir P. Litov

University of Oklahoma

Price College of Business

Norman, OK 73019

litov@ou.edu 


\section{Introduction}

Public markets have undergone dramatic changes in recent years. Most notably, the number of publicly traded firms has been steadily declining, while private capital to fund late-stage startups has become more available (Gao et al., 2013; de Fontenay, 2017; Ewens and Farre-Mensa, 2020; Doidge et al., 2018). Also changing is the nature of the firms that choose to go public. While publicly traded firms in the classic sense are thought of as widely-held firms with dispersed shareholding, many of the firms that have recently elected to go public are tightly controlled by their founders or other entities via a dual-class stock structure. As shown in Figure 1, almost 30 percent of initial public offerings (IPOs) in 2017-2019 had dual-class structures. Well-known examples include IPOs of high-tech firms such as Google in 2004, Facebook in 2012, and more recently, Snap in 2017. Yet, as Adams and Ferreira (2009) state, "few papers tackle the issue of the determinants of dual-class structure... Consequently, we still know very little about this issue." In this paper, we empirically explore the recent rise in dual-class stock IPOs, and present new evidence on the distribution and determinants of voting and economic rights across various stockholder types.

Why do firms adopt dual-class structures at the IPO, and what factors explain their recent popularity? A typical dual-class structure allocates excess voting control to a particular group of shareholders, despite their claim to a much smaller share of cash flow rights. Dual-class structures may entail substantial agency costs, as those shareholders with excess control rights bear only a small proportion of the financial consequences of their decisions, while retaining the ability to forestall takeovers and entrench themselves. Accordingly, from a governance perspective, the increase in dual-class stock IPOs is puzzling. Dual-class structures were historically used infrequently, presumably because the agency costs associated with such structures were high (Goshen and Hamdani, 2015). With institutional shareholders and proxy advisory firms placing growing pressure on corporations to remove provisions that shield managers from shareholder monitoring, such as staggered boards (Cremers, Litov, and Sepe, 2017) and poison pills (Catan, 2019), we might expect dual-class structures to follow a similar declining trend. Moreover, almost half of the IPOs in recent years have been from companies that raised financing from venture capital (VC) firms prior to going public (see Figure 1), and many well-known dual-class stock offerings in recent years are of firms belonging to technology sectors, such as software, that are a main focus for VC investors. VC firms have incentives to design optimal governance systems for their portfolio firms when those firms go public in order to preserve the value of their investment (Baker and Gompers, 
2003; Hochberg, 2012). ${ }^{1}$ Thus, one might expect VC firms to insist on a one-vote one-share system for their portfolio companies at the IPO. In light of these concerns about agency costs, it is natural to ask why IPO firms appear to increasingly be adopting dual-class structures.

A key challenge in exploring the determinants of dual-class firm structures is that not all dual-class firms are the same. While the academic literature has generally treated dualclass firms as a single monolithic "type," measuring excess control rights for directors and officers, in reality, the nature of controllers in different dual-class firms varies widely. In fact, founders are controllers in less than half of dual-class IPOs. The controllers may be directors or officers who are not the founders, parent or holding companies that issued shares in a subsidiary, an extended family that has controlled the firm for generations, or even venture capital or private equity investors that have chosen a structure that allows them to keep control over the firm after the IPO. Furthermore, some dual-class structures are driven by regulatory and tax considerations, rather than by governance considerations.

To break open the dual-class black box, we create a novel database that identifies the shareholders, voting rights and type of controller in each dual-class IPO over the years 19942019. To the best of our knowledge, ours is the first comprehensive study of dual-class stock firms to date to classify and differentiate between various types of controllers and control wedges. Using our taxonomy of dual-class firms, we are able to compute the wedge between the economic and voting rights for different types of controllers, as well as for public shareholders, and to examine the determinants of different types of dual-class firm structures. The wedge for the public shareholders conveys the true measure of the potential agency costs of dual-class firms, since it shows (no matter what kind of controller the company has) how much outsider shareholders' voting rights lag behind their economic rights. To date, studies of dual-class firms have only computed the wedge for directors and officers, which, as we show below, may provide a distorted measure of the controllers' power and the agency costs borne by shareholders.

Our categorization of the different types of dual-class firms illustrates a variety of different motivations underlying dual-class structures that have been largely ignored by existing literature. The most common controllers of dual-class IPO firms are founders (4.9 percent of all IPOs, including single- and dual-class), parent and holding companies (2.3 percent), PE firms (1.0 percent), non-founder directors and officers (0.7 percent), and VC firms (0.4 percent). While the classic example of the founder-controlled software firm may be a salient

\footnotetext{
${ }^{1} \mathrm{VC}$ firms tend to relinquish their controlling stakes at the IPO (Black and Gilson, 1998; Kaplan and Stromberg, 2003; Kaplan, Martel, and Stromberg, 2007), but usually unwind their positions within a year or so following the company's listing (Barry et al., 1990; Field and Hanka, 2001; Iliev and Lowry, 2020).
} 
one, there are many other notable examples of dual-class firms that do not fit this model. For example, Chipotle, a food chain that went public in 2006, was not controlled by its founder, but rather by McDonald's. First Data Corporation, a financial services company that went public in 2016, was controlled by KKR, a well-known private equity firm. In both companies, the directors' and officers' economic rights exceeded their voting rights, and therefore their wedge was negative (whereas the controller-such as McDonald's or KKR-had a positive wedge), and did not reflect the existence of controllers' true superior voting rights. In contrast, our more detailed data allows us to accurately capture the structures and potential agency costs of dual-class firms. More specifically, we find that the rise in dual-class IPOs is associated with an increase in the controlling power of firms' founders. For example, in 2017-2019, a staggering 18 percent of all IPOs were founder-controlled. Thus, while there is wide variation in the type of controllers, the data suggests that the increase in dual-class IPOs is in large part driven by founders' ability to dictate the governance of IPO firms.

More formally, we hypothesize that one determinant of dual-class structures is the relative bargaining power of investors versus founders (Goshen and Hamdani, 2015). When founders have greater bargaining power-for example, due to greater availability of investment capital or hot industry markets-they are more likely to be able to negotiate for greater control rights at the time of IPO, and thus, the firm is more likely to adopt a dual-class structure. This theory is particularly appropriate for explaining the controlling power of dominant founders in software companies, such as Facebook and Snap. As argued by Goshen and Hamdani (2015), such founders place high value on the ability to pursue their visions. A strong bargaining position allows founders to raise capital without losing control over the firm, despite the potential agency costs associated with such control.

To test the bargaining hypothesis, we construct two proxies for the founders' relative bargaining power at the time the firm goes public, predicated in the notion that increased capital availability and outside options for the founder provide increased bargaining power vis-à-vis investors, such as institutional investors. The first is simply the amount of late-stage VC investment at the industry level in the year before the IPO (Goshen and Hamdani, 2015). We focus on late-stage investment because it captures the outside option for a company considering a public offering. The second is the amount of dry powder in the industry, defined as the amount of funds raised, but not yet invested, by VC firms. This captures the amount of funding available for investment, rather than the amount invested. Both proxies reflect the notion that when private financing is readily available, it serves as an alternative to going public (Ewens and Farre-Mensa, 2020). Moreover, greater amounts of available 
funding lead to "money chasing deals," which in turn leads to greater competition among venture capitalists for deals and to a rise in valuations in the private market. The greater availability of funding thus has a direct effect on the bargaining position of the founders at the IPO stage, allowing them to negotiate for greater control rights in a public offering relative to what might be available in a tighter financing environment.

Consistent with our hypothesis, we show that these proxies for bargaining power are positively related to the wedge between founders' voting and economic rights. In contrast, the bargaining power proxies are not positively correlated with the wedges of other controllers, particularly those of non-founder directors and officers and parent or holding companies. This further supports the hypothesis that founder control is driven by founders' bargaining power. All our specifications include industry fixed effects, such that the estimates of the coefficients on VC industry financing measures and industry dry powder are derived from changes in the availability of financing across time. Interestingly, we find no significant relationship in the full sample period between $\mathrm{VC}$ backing and the wedge of founders. Thus, VC firms do not appear, on average, to be averse to founders' voting rights exceeding their economic rights. Moreover, we find that firms with higher levels of innovation, as measured by the value of their patents (Kogan et al., 2017) are associated with higher levels of founder control. This is consistent with the notion that visionary founders often produce innovative technologies. Finally, we find that foreign firms, primarily those based in China, are much more likely to be controlled by founders and have a larger wedge between founders' voting and economic rights.

Our results are robust to a variety of alternative specifications. First, the patterns we document remain substantially the same when we include additional controls for several proxies for "hot" public markets, such as industry returns or the average under-pricing of recent IPOs in the industry. Second, the results are robust when evaluating subsamples of the data that exclude or include only certain types of IPOs, such as VC-backed IPOs. In particular, the results are qualitatively similar when we exclude firms in "cloud industries," which are industries, such as software, that heavily rely on cloud computing technology for data management (Ewens, Nanda, and Rhodes-Kropf, 2018). Thus, our findings are not limited to software firms such as Facebook and Snap.

Third, we provide ample evidence that dual-class structures tend to be determined at the IPO stage. In particular, in examining the certificates of incorporation of a sample of 56 large startups from the Private Capital Research Institute, we find that dual-class structures were created prior to the IPO negotiation process in about 80 percent of these firms. In 
addition, using data from Ewens and Malenko (2020), we find that pre-IPO board control of VC-backed firms does not predict control at the IPO stage. This supports the notion that the availability of $\mathrm{VC}$ financing in the year prior to the IPO affects founders' bargaining power for control rights at the IPO.

Fourth, to address the concern that VC industry financing may be correlated with other factors that may have contributed to increasing the bargaining power of insiders, we develop an instrumental variable for VC financing at the industry level. This shift-share instrument is based on regional shocks in VC financing, where the size of the shock depends on the share of each industry in VC investment in each region. The results suggest that, if anything, the effect of VC financing on the probability of dual-class stock is slightly stronger, and they are robust to excluding firms located in entrepreneurial states, particularly California.

We then turn to explore the historical trends in dual-class firm offerings. We show that historically, founder-controlled dual-class IPOs were less likely to be VC-backed firms, but have become increasingly so in recent years. Second, we show a similar trend in firms that belong to Cloud industries. The introduction of cloud computing in 2006 led to a significant reduction in costs of experimentation, business formation and scaling for software and web-based ventures (Ewens, Nanda, and Rhodes-Kropf, 2018). As a result, such startups became less reliant on VC funding for startup, thus increasing the relative bargaining power of their founders vis-à-vis their investors. Using a difference-in-differences analysis around the introduction of cloud computing, we show that firms in Cloud industries became more likely to adopt dual-class structures that give greater control to founders following the introduction of cloud computing, particularly for VC-backed IPOs. This finding is consistent with anecdotal evidence that $\mathrm{VC}$ firms have become more deferential to entrepreneurs in the software industry (Lublin and Ante, 2012; Alden, 2014; Winkler and Farrell, 2018; Kupor, 2012; Alon-Beck, 2019), and that due to technological changes, software companies now have more options for reaching scale and going public without raising significant funding from VC firms. ${ }^{2}$ Our results are consistent with a diminution in the governance role of VC firms over time that reflects such founders' more powerful bargaining position in the wake of this technological shock. Moreover, we find that the greater propensity of foreign firms (primarily from China) to give founders greater decision-making power is driven by firms in Cloud industries and in more recent periods. This finding is explained by various regulatory restrictions on companies that have prevented founder-controlled firms from listing on the

\footnotetext{
${ }^{2}$ Take one recent example, Veeva, an online customer relationship and content management company, which received only $\$ 7$ million in VC investment but was valued at $\$ 4.4$ billion shortly after its IPO in 2013 . Perhaps unsurprisingly, Veeva has a dual-class stock structure (Schubarth, 2013).
} 
Hong Kong or Chinese stock exchanges.

While many firms go public with a dual-class structure, these structures do not necessarily persist indefinitely. We document the adoption of "sunset" provisions in IPOs of dual-class firms. Sunset provisions specify the circumstances under which the wedge between voting and economic rights ends, typically through the conversion of the dual-class structure into a single-class one with no superior voting rights. The recent debate over sunsets has focused on "time sunsets," which provide that the conversion into a single-class firm occurs at a predetermined time, such as five years after the IPO. While some commentators have suggested that time sunsets are more effective since agency costs at dual-class firms increase with firm age (Bebchuk and Kastiel, 2017), others have questioned their efficacy, claiming time sunsets induce moral hazard (Fisch and Solomon, 2019; Sharfman, 2019). We find that time sunsets are more likely to be included in VC-backed IPOs of dual-class firms, and less so in other IPOs. However, despite a growing trend of dual-class firms adopting such provisions, this trend is substantially weaker for founder-controlled firms due to the increase in founders' bargaining power over time.

Finally, our construction of different "wedges" for founders, VC firms, PE firms, directors and officers, and public shareholders allows us to provide new insights into how dual-class structures relate to IPO firm valuation. We find that the wedge for the founders is positively related to Tobin's Q and price-to-book ratio, while no such relationship exists for other controller types. While valuation measures increase with the founder's wedge, they decrease with the square of the founder's wedge. This suggests that while investors are willing to assign a higher value to a firm driven by a founder's control or vision, they remain skeptical of IPOs where the wedge is extreme; when founders' voting rights far exceed their economic rights, concerns over high agency costs dampen valuation premiums.

Our article makes a number of contributions to the literature. First, our study contributes to the literature exploring dual-class stock structures. We provide the first detailed exploration of the nature and incidence of different types of controllers, and propose new measures for examining the wedges between cash flows and control. Unlike prior datasets, our data allows a nuanced analysis that incorporates the underlying economic motivations of different controllers and an accurate measure of the agency costs faced by public shareholders.

In particular, our findings add to the literature's understanding of the determinants of dual-class structures, which remains relatively unexplored (Adams and Ferreira, 2009). A number of theoretical studies discuss the tradeoffs between agency costs, reputational incentives, and the benefit of locking controlling shareholders into the firm's long-term per- 
formance and reputation (Grossman and Hart, 1986; Hansmann, 1988; Choi, 2018). Early empirical studies suggested that dual-class structures enable controlling shareholders to retain control without having to bear excessive cash-flow risk (DeAngelo and DeAngelo, 1985). The first comprehensive empirical study of dual-class firms, Gompers et al. (2009), suggests that dual-class structures are more prevalent in the presence of private benefits for corporate insiders. Specifically, Gompers et al. (2009) find that dual-class stocks are more likely in the media industry and in eponymous companies. More recently, Iliev and Lowry (2020) explore the relationship between information asymmetries, proxied by variables such as $R \& D$, and dual-class structure, and find no connections. To the best of our knowledge, our article is the first to identify the effect of founder bargaining power as well as valuable innovating activity on the choice of dual-class structure in IPOs.

Our article is also related to research that studies the effect of dual-class structure on performance. Several studies have found that a higher wedge between director and officer voting rights and cash flow rights is associated with lower firm value (Jarrell and Poulsen, 1988; Claessens et al., 2002; Lemmon and Lins, 2003; Smart et al., 2008; Gompers et al., 2009) and managerial extraction of private benefits (Smart et al., 2008; Masulis et al., 2009). Conversely, other studies find no significant association with shareholder value or even find a positive effect (Partch, 1987; Cornett and Vetsuypens, 1989; Dimitrov and Jain, 2006). Smart and Zutter (2003) find that dual-class IPOs are less likely to be under-priced. Consistent with their finding, recent studies suggest that dual-class stock firms exhibit higher valuations around the time of the IPO, although they also find lower valuations when these firms become mature companies (Cremers et al., 2018; Kim and Michaely, 2019). Our new data on the different types of dual-class firms allows us to analyze more concretely which types of control structures are associated with higher valuations. Specifically, we relate findings in Cremers et al. (2018) and Kim and Michaely (2019) to founders' control by showing that IPO valuation generally increases with the size of the founders' wedge between economic and voting rights. However, valuations do not increase when such a wedge is extremely large, nor with the wedge of other controllers, such as parent companies. These results with respect to shareholder value are an important illustration of why we should think of dual-class firms as a collection of very different control structures, rather than a monolithic corporate governance arrangement as in the prior literature.

Second, our paper adds another dimension to the large body of literature on the governance role of VC firms. VC firms monitor their portfolio companies through board representation (Lerner, 1995) and by acquiring information through staged financing (Gompers, 
1995). Kaplan and Stromberg (2003) document that VCs negotiate control rights at the time of their investment and put monitoring and advisory systems in place. Hellmann and Puri (2002) indicate that VCs play a role in the professionalization of startups, including the hiring of outside CEOs (see also Broughman and Fried (2020)). Two studies focus directly on VC firms' impact on IPO firms (Baker and Gompers, 2003; Hochberg, 2012). Both show that VC-backed IPO firms tend to have more independent boards. Hochberg (2012) also shows that VC-backed firms tend to have lower earning management and more positive reactions to the adoption of anti-takeover devices. These findings support the hypothesis that governance is the result of a bargaining process between investors and insiders. Our article extends these studies by focusing on how changes in the relative bargaining power of founders and VCs have affected the most extreme entrenchment device, the dual-class stock structure. Moreover, we not only identify the impact of VC financing at the firm and industry levels, but also document the changes in VC firms' attitudes towards governance over time (Ewens et al., 2018; Ewens and Malenko, 2020).

Third, we contribute to the recent literature exploring the growth in private capital markets that has resulted in companies staying private longer (Gao et al., 2013; Doidge et al., 2018; Ewens and Farre-Mensa, 2020). As shown by Ewens and Farre-Mensa (2020), regulatory changes that resulted in greater availability of private financing contributed to a decrease in the number of public firms. Whereas Ewens and Farre-Mensa (2020) focus on private equity investment, we focus on VC firms, which are the main source of funding for entrepreneurial firms, especially for many of the recent high-tech IPOs, such as Facebook and Snap. Our results suggest that the increase in availability of late-stage capital leads to increased bargaining power for founders vis-à-vis investors at the IPO, leading to an increase in dual-class stock structures in IPO firms. In this sense, our study is related to Lehn et al. (1990), who explore the substitutability of private ownership in which there is no wedge between voting rights and cash-flow rights and dual-class stock structures that keep control in the hands of insiders. Specifically, we show that an increase in the private capital that gives entrepreneurial firms greater financing options from VC firms increase the power of entrepreneurial firm insiders to maintain their control even after the firm becomes public.

Finally, we contribute more broadly to the literature on governance of IPO firms. Much of the literature focuses on adoption of anti-takeover devices. Several studies have highlighted the prevalence of anti-takeover provisions in the governance of IPO firms (Daines and Klausner, 2001; Karpoff and Field, 2002; Iliev and Lowry, 2020). For example, Daines and Klausner (2001) find that anti-takeover devices are used to protect managers when 
takeovers are more likely, and Karpoff and Field (2002) find that managers tend to deploy defenses when their compensation is high and shareholder oversight is weak. Similarly, Field and Lowry (2017) show that after the IPO, mutual funds tend to vote against directors of dual-class stock firms, but not those of firms with classified boards. ${ }^{3}$ However, with few exceptions (Baker and Gompers, 2003; Hochberg, 2012), this literature has not emphasized the impact of founder bargaining power on governance at the IPO stage. Thus, we complement recent studies of controversial IPO governance provisions (Field and Lowry, 2017) by providing a market-based explanation for the rise of dual-class stock. ${ }^{4}$

\section{Conceptual Framework}

We begin with a conceptual framework for the empirical analysis. We lay out a simple model that illustrates how the availability of $\mathrm{VC}$ funding and the resulting higher valuations in the private markets may affect the likelihood of a dual-class structure in an IPO listing. The intuition is that when founders value control over their companies, higher valuations in the private market provide better outside options and make it less advantageous to go public unless the founders have superior voting rights enshrined in the structure of the public firm. Second, we discuss why we might expect to see more dual-class firms in specific IPOs, particularly cloud industries, VC-backed IPOs, and foreign firms. Third, we discuss measures for capturing the innovating activity of dual-class firms.

\section{A. Dual-class Structures and Founder Bargaining Power}

We assume that the founder values both private benefits from control and cashflow or economic rights from dividends. Therefore, the value of the firm to the founder is $V_{E}=\bar{A}+B$, where the first term represents the value of operational control over the company, and the second the sum of economic rights from all the outstanding shares. A VC investor does not value the founder's control over the company as much as the founder does, so the value of the firm to the VC investor under founder control is $V_{V C}=\underline{A}+B$, where $\underline{A}<\bar{A}$.

\footnotetext{
${ }^{3}$ Institutional shareholders have consistently expressed strong opposition to dual-class structures. For example, on October 2, 2012 the Council of Institutional Investors sent letters to the New York Stock Exchange and Nasdaq requesting them to prohibit dual-class stocks in their listing standards. See https: //www.cii.org/dualclass_stock

${ }^{4}$ In this respect, our study is related to other studies that explore market explanations for the prevalence of governance mechanisms, especially in the context of executive compensation (e.g., Cremers and Grinstein (2013); Peters and Wagner (2014); Jenter and Kanaan (2015)).
} 
We assume that the firm needs to raise $I$ amount of investment, and the firm may seek to raise this amount from a $\mathrm{VC}$ investor or in an IPO. To raise this amount from the $\mathrm{VC}$ firm, the founder must relinquish voting power, $\underline{v}=\frac{I}{\underline{A}+B}$. The public shareholders are typically passive, and thus, they place greater value on founder control. Thus, $V_{P U B}=\tilde{A}+B$, where $\tilde{A} \in(\underline{A}, \bar{A}]$. In the IPO, the founder will relinquish voting power, $\widetilde{v}=\frac{I}{\tilde{A}+B}$. Because $\underline{A}<\tilde{A}$, the founder relinquishes more voting power to the VCs than to public shareholders, and thus $\underline{v}>\widetilde{v}$.

So far, we have only considered a single-class IPO. In order to retain control, the founder may own shares with superior voting rights. Let $\mu \geq 1$ represent the number of votes per share owned by the founder. For example, if the founder owns "Class B" supervoting stock that entitles her to five votes per share, $\mu=5$. Let also $p \in[0,1]$ represent the probability that the IPO is successful in attracting a sufficient number of investors. In this setting, the founder decides to go public rather than raise funds from $\mathrm{VC}$ investors if:

$$
p\left(\frac{\mu(1-\widetilde{v})}{\widetilde{v}+\mu(1-\widetilde{v})} \tilde{A}+(1-\widetilde{v}) B\right)>(1-\underline{v}) \underline{A}+(1-\underline{v}) B .
$$

This expression demonstrates a few simple insights. The firm is more likely to go public if $\underline{v}$ is higher or $\widetilde{v}$ is lower, or when the valuation by the public investor $(\tilde{A})$ is higher, and the valuation by the $\mathrm{VC}$ firm $(\underline{A})$ is lower. Also, a higher $\mu$ also makes it more likely that the firm will go public. Thus, if public shareholders are willing to buy shares when the founder has superior voting rights, the founder will be more inclined to go public.

We first examine the firm's incentives when there is high competition among VC firms, and thus more money chasing deals. This means that the valuations by $\mathrm{VC}$ firms will tend to be higher, and therefore, $\underline{A}$ will be higher. We assume for expositional clarity that $\underline{A}=\tilde{A}$, and therefore, $\widetilde{v}=\underline{v}$. The condition in equation 1 simplifies to the following:

$$
\frac{\mu p \underline{A}}{\underline{v}+\mu(1-\underline{v})}>\underline{A}+(1-p) B
$$

Suppose that $\mu=1$. Then, the inequality becomes $p \underline{A}>\underline{A}+B(1-p)$. This means that the firm chooses to remain private because $p \leq 1$. Accordingly, for the firm to do an IPO it must be that $\mu>1$, as the left-hand side is increasing in $\mu$. That is, the firm will only go public if the founder receives superior voting rights. Using $\underline{v}=\frac{I}{\underline{A}+B}$, we can re-write equation 2 : 


$$
\frac{(\underline{A}+B) \mu p \underline{A}}{I+\mu(\underline{A}+B-I)}>\underline{A}+(1-p) B .
$$

As expected, the benefit from going public (i.e., the right-hand side) is increasing in $\mu$ because the founder prefers to maintain control. Moreover, the derivative in $\mu$ is increasing in $\underline{A}$. That is, a greater wedge becomes more likely at the IPO stage when valuations in the private market are increasing, presumably due to greater competition among VC firms for investments.

PREDICTION: The more VC financing is available (such that firms' valuations are higher), the more likely firms that go public are to adopt a dual-class structure whereby the founder gets superior voting rights.

We note that higher public valuations by public investors have a different effect than higher private market valuations. The reason is that if $\tilde{A}$ is higher but $\underline{A}$ stays fixed, then the public investors will demand a smaller share percentage; that is, $\widetilde{v}$ will be smaller. Note that as discussed above, higher $\mathrm{VC}$ valuations are associated-by assumption-with higher valuations by public investors, as otherwise firms are unlikely to go public. The rationale is that an increase in demand by VC firms for a stake in a firm serves as a signal to presumably less informed public investors about the quality of the firm and pushes public valuations higher. Importantly, however, the driver for these increased public valuations is the increase in private capital caused by greater VC firm involvement with entrepreneurial startups, as opposed to (or perhaps in addition to) an independent rise in public valuation.

\section{B. Different Types of IPOs}

The bargaining hypothesis also implies that the incidence of dual-class structures will be higher in industries where the bargaining power of VC firms is weaker. We hypothesize that the likelihood of dual-class structures is higher in industries that have become more capital efficient, in the sense that their dependence on external financing is lower. As recently shown by Ewens et al. (2018), several technological shocks have decreased the costs of starting new businesses of certain types, and thus made it less advantageous for VC firms to invest much capital and effort in monitoring startups' governance in early stages of financing. They identify the advent of Amazon's Web Services ("AWS") in early 2006 as the defining moment that lowered the initial costs of starting a business in the software- and servicerelated industries. Cloud computing reduced the need for startups to make large fixed investments in the early stages of the firm, when the probability of success is still low. 
As a result, VC firms invest smaller amounts in startups and dedicate fewer resources to monitoring their governance. Accordingly, those startups that end up succeeding in the first stage, such as Dropbox and Snap, are widely coveted by many VC firms who seek a bite at the apple. This increases the bargaining power of the founders of successful startups and allows them to maintain their control for the rest of the life of the firm. Thus, it is perhaps unsurprising that software firms have chosen to adopt dual-class structures at the IPO.

Moreover, there is evidence that technological shocks not only reduced the costs of doing business at the startup stage, but also at later stages of the lives of entrepreneurial firms. Specifically, startups tend to use cloud computing several years after the initial stages of financing. Most of the large software and service companies, including Dropbox, Snap, and others, have based a significant portion of their business on cloud infrastructure even after the IPO. Thus, the reduced costs of doing business may also affect firms' need for capital not only at the early financing stages, but also in the pre-IPO stage, when the firm chooses its governance structure. When VCs compete to invest in a successful startup, they may have to allow the founder to retain control after the IPO. In fact, some startups in the software industry accomplish IPOs with dual-class stock without even tapping into VC funding (Schubarth, 2013). Accordingly, we expect a higher rate of dual-class structures and founder control in IPOs of firms that benefited from cloud computing, even for VC-backed IPOs.

Another key factor behind the rise of founder-controlled dual-class IPOs is the growing number of listings by foreign-based firms in the United States, primarily Chinese firms. The percentage of U.S. IPOs represented by China-based firms has gone from about 5 percent in 2005 to almost 20 percent in 2019 (Ritter, 2020). Chinese tech "unicorns" such as Baidu and Alibaba decided not to list on Chinese stock exchanges, either because the exchanges were unsophisticated or because they had strict profitability requirements (Fried and Schoenfeld, 2020). Furthermore, firms listing in China could not opt for a dual-class structure till 2019. The Shanghai Stock exchange eventually had to allow dual-class structures to "stem an exodus of technology firms seeking listings overseas" (Bloomberg, 2019). Previous literature has shown that East Asian and Chinese founders are more committed to controlling their firms, with their voting rights often exceeding economic rights (Claessens, Djankov, and Lang, 2000; Hout and Michael, 2014). Therefore, for a Chinese founder who values control over her company, American exchanges' openness to dual-class structures is a factor that would weigh in favor of listing in the United States.

While Chinese firms constitute about 4 percent of all the IPOs in our sample, they 
represent 15.31 percent of dual-class firms, and 26 percent of dual-class firms controlled by founders. 36.38 percent of American dual-class firms are founder-controlled, compared to 73 percent of Chinese dual-class companies. The growing share of China-based IPO firms, as well as their tendency to be founder-dominated, is one of the reasons we see a rise in founder control over dual-class companies after 2005. Furthermore, a large proportion of these China-based firms are in Cloud industries, so their founders have likely seen their bargaining position relative to $\mathrm{VC}$ investors increase. In this sense, the rise of foreign-and especially Chinese-IPOs in U.S. markets is consistent with the hypothesis about bargaining between the founder and VC investors.

\section{Dual-class Structure and Innovation}

Although this is not our study's main line of inquiry, another possible justification for dual-class firms is that they allow founders to pursue a vision that is embedded in innovative technology (Goshen and Hamdani, 2015). ${ }^{5}$

Accordingly, we evaluate whether dual-class firms, particularly founder-controlled firms, are associated with the filing of more valuable patents prior to the IPO (Kogan et al., 2017). We look specifically at the five-year period prior to the IPO, which reflects the average time for consideration of applications for patents. As discussed below, we find that innovation proxied by the value of patents is positively associated with the probability of dual-class structures, consistent with the notion that more innovative firms may put dualclass structures in place at the time of IPO in order to protect their ability to continue to engage in innovative activity.

\footnotetext{
${ }^{5}$ One possible proxy for innovation is the firms' investment in R\&D. However, existing studies find no relationship between R\&D and the probability of dual-class stock (Iliev and Lowry, 2020), and as we show below, our results confirm this. There are reasons to question whether R\&D is a good proxy for innovation, however (Balasubramanian and Sivadasan, 2011). First, R\&D data does not provide a specific breakdown of expenditures on the activities that led to the patented innovation. It is the number of successful patents that matters, not expenditure on failed projects. Second, a large fraction of firms in the data report zero or little R\&D expenditure, making patenting data a more reliable basis for measuring innovation. Third, the relevant $R \& D$ expenditures may have been made long before the IPO and might not be publicly available to researchers, and therefore data on R\&D when the firm becomes public does not reflect the firm's investment in innovation.
} 


\section{Data and Sample}

\section{A. IPO Data}

The full sample of IPO firms is the set of IPOs from 1994-2019 that are included in the SDC Thomson Reuters database and on Jay Ritter's website. ${ }^{6}$ The SDC data includes general variables representing IPO characteristics such as the IPO offer price, while the data from Jay Ritter includes data on the year each IPO company was founded. We follow the process in Lowry et al. (2017) to fill out and verify all relevant identifiers, such as gvkey, cik, and permno. ${ }^{7}$ We exclude unit offerings, IPOs with an offer price of less than five dollars, and closed-end funds. We include only firms listed on major stock exchanges, namely the New York Stock Exchange, Nasdaq, and AMEX, and firms that are included in the CRSP database. We merge this dataset with financial data in Compustat from the fiscal year that preceded each IPO.

We classify IPOs by four variables: (1) $V C$-backed is an indicator variable that equals one if a firm was financed by VC firms prior to the IPO; (2) Foreign is an indicator variable that equals one if a firm is based outside the United States; (3) CloudIndustry is an indicator variable that equals one if a firm belongs to a Cloud industry; and (4) Media, which is an indicator variable that equals one if a firm belongs to one of the following SIC industry codes: 2710-11, 2720-21, 2730-31, 2840-2849, 3660-69, 4800-99, 7810, 7812, and 7820. ${ }^{8}$

As discussed above, Cloud industries are industries that became more capitally efficient as a result of the introduction of cloud computing. To create the Cloud Industry variable, we follow a similar procedure to Ewens et al. (2018) by searching for keywords, such as software, service, and web, in the companies' business descriptions for all firms in both the VentureXpert dataset and the full SDC IPO dataset. Each set of keywords is associated with one of the twenty-seven industry classifications as described in Table A1 in Ewens et al. (2018) based on the Venture Source database classification. ${ }^{9}$ Cloud industries include Business

\footnotetext{
${ }^{6}$ See https://site.warrington.ufl.edu/ritter/ipo-data/. We thank Professor Ritter for making the data available on his website.

${ }^{7}$ We thank Professor Michelle Lowry for making the online data appendix available on her website. See https://sites.google.com/site/michelleblowry/ipo-review-chapter.

${ }^{8}$ Note that our definition of media companies is slightly broader than that used in Gompers et al. (2009), which does not include 2840-49, 4800-99, or 3660-69. Our definition includes "communications" companies, which allow businesses and individuals to communicate via audio, radio, video, and other methods. We use this definition because it includes the companies which are subject to the cross-ownership regulations of the Federal Communications Commission (FCC), and at least historically some firms adopted dual-class structures to comply with these regulations.

${ }^{9}$ We thank Professor Ewens for his help with the description of treated industry segments in Venture Source and for sharing relevant data on the methodology for creating a mapping from Venture Source to
} 
support services, Consumer information services, Financial institutions and services, Media and content, Medical software and information services, Retailers, Software, and Travel and leisure. We then create a mapping from two-digit SIC codes to the twenty-seven industries, based on the largest number of keywords in the business description of each firm that belongs to each two-digit SIC industry. This allows us to classify each two-digit SIC code as either a "Cloud" industry or a "Non-Cloud" industry. ${ }^{10}$

\section{B. Dual-class IPOs}

To code the data on dual-class structure, we merge the IPO sample with data on dualclass stock from several existing sources: (1) data on dual-class listings from 1994-2002 from Gompers et al. (2009); ${ }^{11}$ (2) data on dual-class IPOs available on Jay Ritter's website; and (3) data collected by the Council of Institutional Investors. ${ }^{12}$ We extend this data on dualclass firms by using the DirectEdgar software and CapitalIQ to identify candidate firms that may have adopted dual-class stock structures. ${ }^{13}$ We manually review the registration statements and the first proxy statements after the IPO of the candidate firms. We remove from the sample dual-class IPOs where the dual-class structure is adopted for tax and regulatory reasons. Tax-driven IPOs include "Up-C" IPOs, which simply exist to allow pre-IPO owners to claim passthrough tax treatment which lowers their tax liability. Regulation-driven dual-class firms include media companies, where the dual-class structure was formed to comply with the regulation by the Federal Communications Commission (FCC) that limits the percentage of voting stock individuals can own across media companies. The final sample includes 5,760 IPOs of which 614 are dual-class firms, comprising 10.66 percent of the total sample.

Figure 1 presents a summary of IPO trends, broken down by type. We use three-year rolling percentages. As can be seen in the figure, there has been a steady increase in the proportion of IPO firms that are dual-class since 2008, and a particularly steep uptick beginning in 2016. The percentage of VC-backed IPOs and IPOs in the Cloud industries is

other industry classifications.

${ }^{10}$ The following two-digit SIC codes are classified as treated: $23,27,31,51,52,53,54,56,57,58,59,60$, $61,62,63,64,65,67,70,73,78,79,82,87$, and 93 .

${ }^{11}$ See https://faculty.som.yale.edu/andrewmetrick/data/. We thank Professor Andrew Metrick for making this data available on his website.

${ }^{12}$ See https://www.cii.org/dualclass_stock

${ }^{13}$ We use various key word expressions to identify candidate firms, such as "class B" and "voting rights" and "five votes" or "ten votes" or "fifteen votes" or "twenty votes" or "twenty five votes" or "thirty votes" or "5 votes" or "10 votes" or "15 votes" or "20 votes" or "25 votes" or "30 votes"). 
relatively stable (with the exception of the dot-com bubble period). There has been a large increase in the percentage of foreign-based IPOs since 2003, and a gradual decrease in the percentage of media companies.

Figure 2 further splits IPOs into Cloud and non-Cloud industries. As shown in Panel A, most of the historical increase in dual-class firms stems from Cloud industries, where the percentage of dual-class IPOs in 2017-2019 exceeds 50 percent. We observe even stronger trends when limiting the sample to VC-backed IPOs (Panel B) and foreign firms (Panel C), with dual-class firms exceeding a staggering 50 and 60 percent of IPOs respectively.

\section{A Taxonomy of Dual-class Firms by Controllers}

To identify controllers in our sample firms, we collect detailed data from firm proxy statements. A major contribution of our study is to show that not all dual-class stock structures are the same. Whereas previous research treats dual-class IPOs as a binary classification (i.e., an IPO firm either has or does not have a dual-class structure), we demonstrate the existence of a wide range of dual-class structures-some entrenching founders, others giving a holding company or private equity firm control, and so on.

We classify control over dual-class stock firms based on where voting power and operational control of the company are situated. For example, if one shareholder has more than double the voting power of any other, and is also the chairperson of the board, he or she is clearly the controller. One common class of controller is the firm founder. Most firms identify their founders by name in their registration or proxy statements. We double-check the histories of each IPO firm using Factiva and internet research to make sure we do not miss any founder who is not identified as such in the SEC filings. Founders, however, are not the only class of controllers, nor are they the majority class: in fact, a majority of dual-class firms are controlled by non-founder agents.

First, dual-class stock firms may be controlled by parent or holding corporations. For example, when the fast food chain Chipotle went public in 2006, it was not controlled by Steve Ells, its founder, but by a subsidiary of McDonald's. McDonald's owned most of the supervoting shares and had control of 87 percent of the voting rights, with a 22 percent wedge. McDonald's had financially supported Chipotle, leasing out office and restaurant space as well as providing insurance, software and tax assistance. ${ }^{14}$ Second, investors in the firm often serve as controllers, and often, a VC firm or a private equity ("PE") firm may

\footnotetext{
${ }^{14}$ See

https://www.sec.gov/Archives/edgar/data/1058090/000104746906005769/ a2169737zdef14a.htm
} 
control the firm in the IPO, possibly due to a desire to influence the business in the first years in which the firm is public. ${ }^{15}$ To make sure we are not identifying a VC investor as $\mathrm{PE}$ (or vice versa), we scan the regulatory filings, VentureXpert, SDC, and the news media to determine the role played by the investor. In some cases, control may also be shared between the founder and a VC firm. ${ }^{16}$ Control may also be maintained by directors and officers who are not the founders. For example, Skysat Communications Network, which went public in 1994, was controlled by directors and officers who were not founders of the company. ${ }^{17}$ Other categories include family control, control by investors which are not VC or PE firms, and in a few cases, there is no clear controller. ${ }^{18}$

A primary measure of interest for a dual-class firm is the "wedge" between voting and economic rights for key economic actors within the firm. While prior literature computes the wedge solely for directors and officers, regardless of the actual structure in place, we compute this wedge separately for founders, VC firms, PE firms, non-founder directors and officers, and public investors. Note that the wedge for any of these agents can be positive even if they are not the controllers. For example, the founder may have a positive wedge even if a VC controls the firm. ${ }^{19}$

By calculating different wedges for different agents, we allow for a more accurate measure of the motivations for different types of dual-class firms than prior literature, which follows Gompers et al. (2009), and focused exclusively on the wedge for directors and officers. Measuring the wedge solely for directors and officers has a number of drawbacks. First, it camouflages the extent to which founders (rather than other insiders) control the organization. For example, in some firms, such as Dropbox, some founders were also directors and officers at the IPO, but the wedge of the other directors was actually negative. ${ }^{20}$ Moreover,

\footnotetext{
${ }^{15}$ These firms will typically sell their shares after a few years, and the firm then converts into a single-class firm. We do not discuss conversions in this article.

${ }^{16}$ This situation arises when the founder and $\mathrm{VC}$ have approximately equal voting rights and operational control, and/or the VC is in charge at the time of the IPO but exits the company soon after, leaving the founder in charge. For example, Edison Schools, a company that went public in 1999, was controlled by a consortium of VC firms. However, by 2002, they had exited the company, and the founder was in charge. We code such companies as controlled by "Founders and VC."

${ }^{17}$ Skysat's directors and officers owned a majority of the supervoting Class B shares, and had 42 percent of the total voting power in the company, with a 22 percent wedge.

${ }^{18}$ For example, Waddell \& Reed Financial Inc. had widely dispersed ownership with no clear controller. In fact, the largest holder of the supervoting Class B shares was an institutional investor (T. Rowe Price). See https://www.sec.gov/Archives/edgar/data/1052100/0001047469-99-010633.txt

${ }^{19}$ For example, Datadog, which went public in 2019, was controlled by the VC firms Index Ventures and ICONIQ Strategic Partners. However, the two founders, Olivier Pomel and Alexis Le-Quoc, had a large positive wedge of 15 percent. See https://www.sec.gov/Archives/edgar/data/1561550/ 000119312520119035/d914423ddef14a.htm

${ }^{20}$ The founders, Andrew Houston and Arash Ferdowsi, had a 24.5 percent wedge, while the non-founder
} 
as stated above, some firms, such as Skysat, may actually be controlled by directors who are not the founders. The determinants of the wedge of founders and other insiders likely differ because the founders are those who typically place a high value on their vision for the firm. Second, this measure can be entirely misleading when the controllers are not directors or officers, and dual-class structures exist for reasons other than to entrench management. As an example, consider the case of Weider Nutrition International, which went public in 1997. The parent company, Weider Health and Fitness, owned all the supervoting Class B stock, which gave it ten votes per share. Accordingly, the holding company was the controller, wielding more than 98 percent of the aggregate voting power. The controller wedge for the holding company was 31 percent. If we had defined the wedge only for the directors and officers, however (in accordance with prior literature), we would have computed a negative wedge of -3.4 percent, since the directors do not hold any Class B stock.

Importantly, we also compute the wedge for public shareholders. Note that this wedge is typically negative, because public shareholders' voting rights are typically lower than their economic rights. ${ }^{21}$ We define "public" investors as those without prior contractual or business relations with the company. Accordingly, institutional and retail investors are classified as public investors, whereas a party that had a business relationship or personnel interlock with the company is not. ${ }^{22}$ This public shareholder wedge ("public wedge") is a direct measure of the firm's agency costs, as it captures the extent to which public shareholders relinquish voting power to other agents.

Figure 3 shows the variety in dual-class structures by type of controller. The largest group is founder-controlled dual-class firms (including those where control is shared with a VC firm) that constitute 4.9 percent of all IPOs (including single-class firms). The second largest group is dual-class firms controlled by a parent or holding company, with 2.3 percent of all IPOs. All the other dual-class companies controlled by a private equity firm, directors and officers (who are not the founders), or a family, constitute 1 percent or less of total IPOs. In Panels B through E, we split the sample into different types of IPOs. While the percentage of founder-controlled dual-class firms is similar in VC-backed and non-VC-backed

directors and officers had a small negative wedge. See https://www.sec.gov/Archives/edgar/data/ 1467623/000114036119006800/nc10000579x1_def14a.htm

${ }^{21}$ However, this is not always the case. For example, Validus Holdings went public in 2009 with the controllers, a PE consortium, holding all the nonvoting Class B shares. The public only owned Class A shares, which had one vote per share, so their wedge was positive. See https://www.sec.gov/Archives/ edgar/data/1348259/000095012309009473/x76143dmdefm14a.htm

${ }^{22}$ For example, we exclude Urknall Inc. from the definition of "public" for the Canaan, Inc. IPO, because it is controlled by Xiangfu Liu, a cofounder of Canaan who subsequently left the company. See https:// www.sec.gov/Archives/edgar/data/1780652/000156459020016788/can-20f_20191231.htm (p. 85-86). 
IPOs, the percentage of company-controlled dual-class IPOs is much smaller for VC-backed IPO firms. The percentage of founder-controlled dual-class firms is higher among foreignbased firms (14.8 percent) as compared to US-based firms (3.6 percent), and among firms in Cloud industries (6.9 percent) as compared to firms in other industries (3.0 percent). There is a higher percentage of dual-class firms, both founder and company controlled, in the media industry. However, as noted above, media IPOs have largely disappeared in recent years.

\section{Sunsets}

For each dual-class IPO firm, we further examine SEC filings to identify "sunsets," i.e. clauses in the firm's organizational documents that cause the firm's stock to convert into one class, without any differential voting rights, at a prespecified time or event. There are four types of sunset provisions in the sample: time sunsets, ownership sunsets, transfer sunsets, and sunsets triggered by other events. Each firm may have one or more than one type of sunset provision.

Time sunsets cause the elimination of dual-class at a pre-specified point in time. For example, when Groupon went public in 2011, its prospectus specified that "no shares of common stock will be issued or outstanding until five years after the completion of this offering, at which time all outstanding shares of Class A common stock and Class B common stock will automatically convert into shares of common stock." ${ }^{23}$

Ownership sunsets cause supervoting shares to convert into shares with just one vote when the controller owns less than a prespecified percentage of the company's total outstanding shares, or if the number of supervoting shares falls below a prespecified percentage of the total number of outstanding shares. For example, in the 2004 IPO of Texas Roadhouse, all the shares convert into single-class with one vote per share if the shares owned by the founder represent less than 20.0 percent of the total number of both the superior voting shares and the other common shares. ${ }^{24}$ The rationale is that the controller loses her superior voting rights if her economic interest is too low.

Transfer sunsets cause any supervoting shares that are sold to entities other than a list of transferees explicitly listed in the registration statement (typically other founders and controllers) to convert into non-supervoting shares. In Google's 2005 IPO, its registration statement provided that any supervoting Class B shares would convert into Class A shares upon sale, except for transfers between Larry Page and Sergey Brin (the company's co-

\footnotetext{
${ }^{23}$ See urlhttps://www.sec.gov/Archives/edgar/data/1490281/000104746911008854/a2205238zs-1a.htm

${ }^{24}$ See urlhttps://www.sec.gov/Archives/edgar/data/1289460/000104746904030247/a2137984zs-1a.htm
} 
founders), or transfers made for estate planning and tax purposes. ${ }^{25}$

Finally, we coded "other" event sunsets. These typically mandate the conversion of supervoting shares upon a founder's death or disability. Workday's 2013 IPO provided for the conversion of supervoting shares nine months after the last of the cofounders had died. ${ }^{26}$ We created separate indicator variables for each of these subcategories of event sunsets.

\section{E. VC Funding Measures}

We source data on $\mathrm{VC}$ investments at the year-industry level from VentureXpert. To capture of the volume of VC funding in the industry, which serves as our proxy for the relative balance of investor versus founder bargaining power, we construct two measures, each measured at the year level. First, VC Ind. Financing denotes the total amount of VC investment (in $\$$ billions) in companies that belong to each industry based on two-digit SIC codes. In calculating the amounts of $\mathrm{VC}$ investments we include only investments classified as "later stage," "expansion," or "buyout/acquisition" in VentureXpert. The reason is that early-stage investment or seed capital are unlikely to improve the bargaining power of founders at the pre-IPO stage.

Second, Dry Powder denotes the total dollar amount (in billions) of capital available for investment by VC funds that invest primarily in each industry. Because VentureXpert does not include the amount of money invested by each fund in each company financing round, We follow Hochberg et al. (2015) and Barrot (2016), and compute an imputed amount by weighting the total $\mathrm{VC}$ round amount by the average amount each $\mathrm{VC}$ fund invests in each round. The amount of available capital is the amount of capital raised by each VC fund minus the total amount of capital it invested after the fund was created (in $\$$ billions). We allocate VC funds to industries (based on two-digit SIC codes) based on the industries in which they made the largest number of investments in a given year. We then sum across industry-funds to compute the total amount of dry powder for each year-industry. To account for outliers, we winsorize all three measures at the $1 \%$ level.

Figure 4 presents the trends in total VC investments (Panel A). VC financing has increased considerably from 2006, primarily in companies in Cloud industries. We observe similar trends in total VC late-stage investments (Panel B), and dry powder (Panel C).

\footnotetext{
${ }^{25}$ See urlhttps://www.sec.gov/Archives/edgar/data/1288776/000119312504142742/ds1a.htm

${ }^{26}$ See urlhttps://www.sec.gov/Archives/edgar/data/1327811/000119312512420693/d385110ds1a.htm
} 


\section{F. Firm Characteristics, Financials and Intellectual Property}

We construct a number of additional variables to capture an IPO firm's characteristics and financials. Age is the difference between the year of the IPO and the year the company was founded. Eponymous is an indicator equal to one if a firm's name at the IPO includes a person's name. The rationale is that if the company bears a founder's name, such naming might reveal a personal stake in the business and thus the desire to maintain control. For observations from 1994-2002, we use the variable from Gompers et al. (2009), ${ }^{27}$ and for the rest of the sample, we manually review firm names. IPO Proceeds is the proceeds in $\$$ millions raised in the IPO. Assets is the book value of assets in $\$$ millions. Leverage is long-term debt divided by book value of assets. Cash is the ratio of cash and short-term investments to total book assets. $R O A$ is return on assets calculated as operating income after depreciation divided by book assets in the previous year. $R \& D$ is the ratio of research and development expenditures over total book assets (normalized to zero if missing), and Missing $R \& D$ is an indicator equal to one if $R \& D$ is missing. Of course, $R \& D$ may be a poor measure of firms' innovation. Accordingly, we construct an additional measure, Patents, which is the real value of the patents in $\$$ millions filed by an IPO firm in the five-year period prior to the IPO using the data in Kogan et al. (2017). ${ }^{28}$

Table I presents the summary statistics. In columns 1-4, we show the data for single-class firms; in columns 5-9, the data on founder-controlled dual-class firms (including those where control is shared with a VC firm); and in column 10-14, the data for other dual-class firms. As shown in Panel A, the age of founder-controlled dual-class firms at IPO is lower than for single-class firms, but other dual-class firms are much older. The proceeds of all types of dualclass firms are larger, but those not controlled by a founder have substantially more assets. All types of dual-class firms have higher return on assets (ROA). Interestingly, the value of patents for founder-controlled firms is substantially larger than the value for other types of firms (although the number of patents produced by both groups is similar). Arguably, the value of the patents captures the innovative nature of founder-controlled firms. However, dual-class firms spend less on R\&D as compared to other firms. Finally, founder-controlled firms have higher Tobin's Q and price-to-book ratio at the IPO, but other dual-class firms have a lower Tobin's $Q$ and statistically indistinguishable price-to-book ratio, suggesting that the market assigns a higher value to dual-class firms that are founder-driven.

\footnotetext{
${ }^{27}$ We thank Professor Andrew Metrick for sharing these data with us.

${ }^{28}$ We use five years as the cutoff because this is the average time before a patent application is approved or dismissed.
} 
In Panel B, we look at IPO type. Founder-controlled firms are just as likely to be backed by VCs as single-class firms, but other kinds of dual-class firms are less likely to be VCbacked, in large part because when the controller is a corporation or a PE firm, VCs are not needed for the firm to raise capital. Founder-controlled firms, and to a lesser extent other dual-class firms, are especially prevalent among foreign-based firms and in Cloud industries. Finally, a large percentage of dual-class IPOs where the controller is not a founder involve a spin-off (36 percent). These typically involve a corporation that lists a subsidiary on a stock exchange, and may wish to maintain control after the IPO.

Panel $\mathrm{C}$ presents the main dependent variables we will employ in our analysis. The average public wedge in the sample is -17.2 percent, but is larger in founder-controlled firms (-22.7 percent) as compared to other dual-class firms (-12.7 percent). As expected, the founder wedge is high for founder-controlled IPOs (25.5 percent), and so is the wedge of directors and officers, since the founders tend to serve as directors or officers. Similarly, the wedge for corporations is much higher in non-founder-controlled IPOs (7.9 percent), which are mostly controlled by parent or holding corporations, and other wedges are all smaller.

In Panel D, we show data on sunsets. Time sunsets are relatively rare and are adopted in only about 8 percent of dual-class firms. Ownership sunsets are adopted in about 25 percent of dual-class firms. Transfer sunsets are more frequent, particularly in founder-controlled firms.

Finally, in Panel E, we show the descriptive statistics for the proxies for founders' bargaining position (VC Ind. Financing and Ind. Dry Powder). These measures are all substantially larger for founder-controlled firms than for the single-class firms and other dual-class firms. This is consistent with the notion that market conditions that give founders the leverage to negotiate for control relate, at least in part, to IPO governance and structure.

\section{The Determinants of Dual-Class Structure}

We now turn to examine the determinants of different types of dual-class structures. We start with an analysis of the factors that predict a dual-class structure and the different types of controllers that use dual-class structures. We estimate a regression model of the form:

$$
\text { Controller }_{i, t}=\beta V C I_{j, t-1}+\gamma V C-\text { Backed }_{i}+\delta X_{i, t-1}+\eta_{j}+\mu_{t}+\varepsilon_{i}
$$

where Controller Co $_{i, t}$ is an indicator variable that equals one if firm $i$ has adopted a particular type of dual-class structure at the IPO in year $t$. We first examine specifications where 
the dependent variable is Dual - Class, which is an indicator variable that equals one if a firm has a dual-class structure at the IPO. We are particularly interested in specific types of dual-class controllers: Founder Control, which is an indicator variable that equals one if the controller is the founder; NF Dual, which equals one for dual-class firms not controlled by the founder; NF D\&O Control, which is an indicator variable for control by directors and officers who are not founders; and Co. Control, which is control by a holding or parent company.

The key variable of interest for exploring the role of founder bargaining power in determining dual-class structures at the IPO is $V C I_{j, t}$, which is one of the two measures of $\mathrm{VC}$ financing for industry $j$ in year $t$ : (a) VC Ind. Financing, which is the dollar amount of venture capital financing (in billions) provided to companies (excluding early-stage investments) in the industry $j$ to which firm $i$ belongs in year $t-1$, i.e., the year before the IPO; and (b) Ind. Dry Powder, which is the total dollar amount (in billions) of capital available for investment by funds that invest primarily in industry $j$ in year $t-1$.

Another variable of interest is $V C-$ Backed $_{i}$, which is an indicator variable that equals one if the firm received funding from a VC firm prior to the IPO. Prior literature argues that VC firms have incentives to design optimal governance systems for their portfolio firms when those firms go public in order to preserve the value of their investments (Baker and Gompers, 2003; Hochberg, 2012). We thus might expect VC-backed firms to be less likely to adopt dual-class structures at the time of IPO.

$X_{i}$ refers to a set of firm-level controls, which include Spin - off, an indicator variable equal to one if the IPO involves an offering of a subsidiary corporation. Although our main variable of interest is at the industry-year level, we include industry fixed effects based on two-digit SIC codes, $\eta_{j}$. This ensures that the identification of the main coefficient of interest, $\beta$, comes from changes in $\mathrm{VC}$ financing or dry powder at the industry level over time, and not from general industry characteristics. We also include $\mu_{t}$, which are year fixed effects to account for annual trends. Finally, the $\varepsilon_{i}$ is a firm-specific error term.

The results from the regression model in Equation (4) are in Table II. In columns 1-5, the proxy for the bargaining power of founders is VC Ind. Financing. The greater the bargaining power of the founder, the more likely an IPO firm is to be dual-class. As expected, we obtain a similar result when the dependent variable is founder control, Founder Control. On the other hand, the coefficient on VC Ind. Financing is not significant when the dependent variable is NF Dual (column 3), NF D\&O Control (column 4), or Co. Control (column 5). The estimates are economically significant: a one standard deviation increase 
in VC Ind. Financing (equivalent to $\$ 5.62$ billion) is associated with about 3.1 percentage points higher probability of founder control, relative to the unconditional mean of 4.9 percent of the firms in the sample that are founder-controlled. We obtain similar findings in columns 6-10, where we use Dry Powder as a proxy for founders' bargaining power. A one standard deviation increase in Ind. Dry Powder (equivalent to $\$ 30.34$ billion) is associated with about 2.9 percentage points greater probability of founder control. The estimates in both specifications are consistent with the hypothesis that the availability of $\mathrm{VC}$ financing increases the bargaining power of founders, rather than that of other potential controllers.

Other differences between founder control and control by other agents, such as nonfounder directors or holding companies, also emerge from the analysis. The coefficient on $V C-$ Backed is not statistically significant when we examine the probability of dual-class structure or founder control, belying the notion that VCs may prevent dual-class structures at the time of IPO. Note, however, that the coefficient on $V C-$ Backed is negative when examining dual-class firms where the controller is not the founder, and this association appears to be driven by the inclusion of dual-class firms controlled by a parent or holding company in our sample. This may be because VCs are unlikely to invest in firms which are controlled by a large corporation, rather than because VCs dislike entrenchment via dual-class structures. As expected, we find that dual-class firms controlled by a corporations are more likely to involve a spin-off, whereas spin-offs are negatively associated with founder control. Dualclass structure may be used by corporations to maintain control over subsidiaries after the issuance of stocks to the public, likely for strategic reasons.

The estimates from the models also suggest that the value of patents is higher in foundercontrolled firms as compared to single-class firms and other dual-class firms. This hints at the possibility that part of the motivation for founder control is to pursue a particular founderspecific vision which is grounded in innovative technology. In contrast, the coefficient on Positive $R \& D$ is negative, suggesting that the innovativeness of these firms may not be reflected in investment on research and development at the time of the IPO. Moreover, as expected, founder-controlled firms tend to belong to Cloud industries, are more likely to be foreign firms, and tend to be younger firms.

Next, we evaluate whether the size of the wedge between economic and voting rights is related to the founders' bargaining power at the time of IPO. We estimate similar models to those in Table II, substituting the size of the wedge as the dependent variable:

$$
W_{e d g e_{i, t}}=\beta V C I_{j, t-1}+\gamma V C-\text { Backed }_{i}+\delta X_{i, t-1}+\eta_{j}+\mu_{t}+\varepsilon_{i},
$$


where $W e d g e_{i, t}$ is the size of the wedge at the IPO in year $t$. We examine the following wedges: the wedge of the public shareholders (Public Wedge), the wedge of the founders (Founder Wedge), the wedge of directors and officers (D\&OWedge), the wedge for directors and officers who are not founders ( $N F D \& O W e d g e$ ), and finally the wedge of parent or holding companies (Co. Wedge).

The results are presented in Table III. As shown in columns (1) and (6), public shareholders have a lower wedge when founders have greater bargaining power. On the other hand, as expected, the Founder Wedge increases when VC industry financing is more available: a one standard deviation increase in VC Ind. Financing is associated with a 1.12 percentage point lower public wedge for each IPO and a 1.37 percent higher founder wedge. Likewise, a one standard deviation increase in Dry Powder is associated with a 1.00 percentage point lower public wedge for each IPO and a 0.80 percentage point higher founder wedge. This is an economically meaningful result given that only about 10 percent of IPO firms in the sample have dual-class structures.

Interestingly, as shown in column (3), the magnitude of the association with the $D \& O$ $W e d g e$ is slightly higher, suggesting that insiders other than founders may also have greater bargaining power when VC financing is more available (recall that the D\&O Wedge measures the wedge for all directors and officers, which would typically include any founder). Consistent with this, in column (4) we find that NF D\&O Wedge is likewise associated with $V C$ Ind.Financing (and the magnitude of about 0.05 reflects roughly the difference between the coefficients in columns 2 and 3). However, in light of the findings in Table II where VC financing does not predict directors' and officers' control, this association likely reflects the higher wedge of some insiders that are affiliated with the founders in firms controlled by the founders.

Unsurprisingly, we find no evidence of a statistically significant relationship between Co.Wedge and VCInd.Financing; presumably, there is no negotiation for financing between VC firms and parent or holding companies. On the other hand, these firms are nonetheless dual-class firms where public shareholders may have inferior voting rights. These results are qualitatively the same when we use Ind. Dry Powder as a proxy for VCs' bargaining power.

The coefficients on other variables are generally in line with the findings in Table II. Importantly, $V C-$ Backed is not significantly associated with Founder Wedge and is negatively related to Co. Wedge; Spin - off is positively associated with Co. Wedge and is negatively associated with Founder Wedge; and the value of patents is positively related to Founder Wedge. Note that the value of patents is also positively associated with 
$D \& O W$ edge but not with $N F D \& O W e d g e$, which means that the positive association is driven by the wedge of founders, not that of other directors and officers.

The results are qualitatively the same when employing univariate specifications that only include the measure of VC bargaining power as shown in Table A.1 and Table A.2.

A potential concern with our analysis is that VC funding or available capital at the industry level does not only capture the bargaining power of VC firms vis-à-vis founders. Rather, it could proxy for industry conditions in which there is a high or low demand for certain stocks. In these circumstances, the demand for stocks offered at the IPO may be so high that insiders can sell to outsiders stocks with restricted voting rights at relatively high prices. To address this concern, we run the same regressions, but add three proxies for "hot public markets." These measures are: (1) Ind. Returns: the 12-month industry portfolio returns in the month prior to the IPO and winsorized at the $1 \%$ level; (2) Ind. Under pricing: The average under-pricing of all IPOs that belong to each industry in year $t-1$. This is essentially the average first-day returns on all industry IPOs in the year prior to the IPO; (3) Ind. Avg. Proceeds: The average proceeds of all IPOs in each industry in year $t-1$. All variables are based on the Fama-French 48 Industry classification. We also add controls for VC Financing or Dry Powder, which are the total amount of VC financing or dry powder in year $t-1$.

Moreover, it is possible that dual-class structures are adopted more frequently in response to industry merger waves. As is well-known, dual-class structures serve as an anti-takeover device because they make it virtually impossible for outsiders to acquire control. To address this possibility, we add two more variables: (1) Ind. M\&A Num., which is the natural $\log$ of the number of merger transactions completed in the industry in year $t-1$; and (2) Ind. $M \& A$ Value, which is the natural log of the number of merger transactions completed in the industry in year $t-1$. Both measures are based on two-digit SIC codes.

The results are presented in Table IV. We observe little statistically significant correlation between the public market measures and our measures of dual-class structures, regardless of the specification. Industry returns and total dry powder are significantly related to measures of founder control, but not to dual-class structure or to the public wedge, which arguably best captures the agency cost for the public shareholder. More strikingly, industry underpricing is negatively associated with dual-class and founder control and founder wedge, and positively related to public wedge. This corroborates the notion that controllers may tend to do IPOs with dual-class structures when market conditions enable issuers to price their stocks at higher valuations. Interestingly, we also find no evidence that dual-class structures 
are adopted as a response to industry merger waves. This result contrasts with earlier studies that find that dual-class structures are adopted as a response to takeover activity (Daines and Klausner, 2001).

Importantly, even when adding these additional controls, the coefficients on $V C$ Ind. Financing and Ind. Dry Powder are largely the same as those reported in Table II and Table III. These results are consistent with the notion that dual-class structures are not simply the result of high demand for IPO stocks. Rather, they appear to be directly related to the availability of private capital at the firm and industry level, and the relative bargaining power of founders and VC investors. This is consistent with both our conceptual model, which suggests that valuations by VC firms push IPO valuations upwards, and the idea that a dual-class structure is a substitute for private ownership (Lehn et al., 1990).

\section{A. Different Types of IPOs}

Our analysis up to now has included the full sample of IPO firms. Next, we explore whether our findings are driven by a particular subsample of the data, such as VC-backed IPOs and Cloud industries, that are known to produce many founder-driven businesses. We re-run our main specifications on different subsamples: VC-backed IPO versus IPOs not backed by VCs, firms in Cloud industries versus firms in other industries, and US firms versus foreign-based firms. Table $\mathrm{V}$ presents the estimates from our models. Panel A includes regressions where the dependent variable is either Dual-Class or Founder-Control, and Panel B reports results from specifications where the dependent variable is the PublicWedge or Founder Wedge. Each panel also shows results from regressions where we use either VC Ind. Financing or Ind. Dry Powder as a proxy for VC bargaining power.

As can be seen from the table, the relationships observed in Table II hold more generally across multiple subsamples. In particular, even in dual-class IPOs that are not backed by VCs, and in IPOs that are not in Cloud industries, we observe that in most specifications, greater industry VC capital is associated with a higher likelihood of dual-class and founder control, a more negative public wedge, and a higher founder wedge. The results also hold when we restrict the sample of firms to a smaller sample of 625 foreign firms, particularly when the dependent variable is Ind. Dry Powder. Overall, the analysis suggests that the patterns uncovered in the full sample do not appear to be driven solely by a particular segment of IPO firms. 


\section{B. VC-backed IPOs}

To further explore the bargaining hypothesis, we focus on VC-backed IPOs. Bargaining between founders and insiders and investors over structure at the IPO is likely to be particularly acute in IPO firms with existing VC investors. Accordingly, we next conduct more detailed analysis in the sample of VC-backed IPOs. The underlying assumption is that governance is part of the terms of the investment, and may be determined by the bargaining position of the VC firm and the entrepreneur.

The focus on the sample of VC-backed IPO firms allows us to obtain additional proxies for VCs' bargaining positions. We merge the sample of VC-backed IPOs with firm-level data from VentureXpert. Because there is no common identifier for the IPO data and VentureXpert, we do the matching based on firm names. This matching process results in a sample of 1,802 VC-backed IPOs (out of 2,025 VC-backed IPOs in the full sample) for which information on the VC firms that invested in the firm pre-IPO can be obtained.

Using the data from VentureXpert, we construct a number of variables that may relate to $\mathrm{VC}$ and founder bargaining power and therefore affect dual-class structures. $V C$ Rounds is the number of $\mathrm{VC}$ financing rounds a firm undergoes prior to the IPO. In each round of financing, VC firms tend to negotiate for control through contractual rights and the appointment of board members (Kaplan and Stromberg, 2001, 2003; Ewens and Malenko, 2020). $V C$ Firms is the number of VC firms that provided financing to the firm. When the founder negotiates with multiple VCs, she may be better able to maintain control over the firm as compared to a situation when only one $\mathrm{VC}$ is ready to fund the firm. Moreover, coordination problems between VC firms may also lead to better negotiation outcomes for the founder. VC Firm Age is the maximum age at the time of the IPO of the VC firms that supported the IPO. The assumption is that more mature VC firms have better reputations (Barrot, 2016), and may as a result have more bargaining power vis-à-vis the founder. VC Firm Size is the amount of funds in $\$$ millions raised by the largest VC firm prior to the IPO. Typically,

funds that have raised large sums of money do so because they have better past performance and better reputations, and thus may have greater ability to negotiate control terms.

Table VI presents estimates of models similar to those in Equation (4) and Equation (5) for the sample of VC-backed IPOs. As before, all measures of VC industry-wide investment are positively related to the probability of dual-class IPOs, founder-controlled IPOs, a larger-magnitude (negative) public wedge and a higher founder wedge. A one standard deviation increase in $V C$ Ind. Financing (equivalent to $\$ 6.29$ billion) is associated with a 2.78 percentage point and 1.84 percentage point higher probability of dual-class structure 
and founder control. These figures are economically meaningful given that the percentage of dual-class and founder-controlled firms in this sample are only 6.45 percent and 3.91 percent, respectively.

Additionally, we observe a significant relationship between the number of VC rounds the firm has had pre-IPO and dual-class structure at the IPO. Having one additional round of $\mathrm{VC}$ financing prior to the IPO is associated with a -0.8 percentage point probability of founder control. Likewise, a one standard deviation increase in VC rounds (3.1) is associated with a 0.56 percentage point higher public wedge and a lower founder wedge. The other VCrelated variables all have the expected signs, but they are not statistically significant in most specifications. For example, higher VC firm age and larger VC firm size are (insignificantly) negatively related to the probability of founder control.

\section{Bargaining Power Prior to the IPO}

Our study is focused on governance at the IPO stage. It is well-known that firms reevaluate their governance structures at the IPO. Thus, often, the dual-class structure is determined at the IPO together with all other governance provisions, including the state of incorporation, board structure, and anti-takeover devices. However, it is also possible that in some cases, a dual-class structure is created earlier, either when the firm is founded or during $\mathrm{VC}$ investment rounds when the founders negotiate control rights with the VC investors.

We conduct numerous qualitative and quantitative analyses to explore this issue. First, we conducted several interviews with partners at law firms that advise entrepreneurial startups. Based on our conversations, it appears rare for dual-class structures to be created before the IPO. Founders' bargaining power may affect VCs' board seats or their contractual rights, but does not typically result in a wedge between the shareholders' economic and voting rights.

Second, we obtain a sample of 56 certificates of incorporation of large VC-backed dualclass firms before the IPO from the Private Capital Research Institute. The selection is random except that it relates to large, high-profile startups that ultimately became public, such as Dropbox, Facebook, Google, Lyft, and Zoom. This is a sample of firms where a dualclass structure is more likely to be created before the IPO stage because many VC firms may be looking to invest in these companies, creating competition that favors founder negotiating power, and where the founders may wish to maintain their control. In a sample of 56 firms, we find that the dual-class structure was created before the IPO negotiation period in only 13 firms (23.2 percent). On average, the dual-class structure was created 6.3 years prior 
to the IPO for these 13 firms. In one of these 13 firms, both classes of common stock were entitled to one vote per share before the IPO, and therefore the wedge was zero. Importantly, these 13 firms were established on average 15.5 years before their IPO, indicating that the dual-class structure was adopted only in the last third of their lives as private firms. Next, 43 firms (76.8 percent) in our sample adopted dual-class form about nine months before their IPO (i.e., 278.4 days), indicating that most of the sample firms choose dual-class stock structure within the IPO negotiation period.

Third, we merge our data to data on pre-IPO board structure from Ewens and Malenko (2020), who document the extent to which founders or VC firms control the board in a sample of startups that obtained financing through Regulation $\mathrm{D}$. The merged data include a sample of 233 VC-backed IPOs, 28 of which are dual-class firms. Out of the 28 dual-class firms, 13 are controlled by the founders at the IPO, nine are controlled by VC firms, and six are jointly controlled by founders and VC firms. Somewhat paradoxically, we find that VC investors controlled the boards of 62 percent of the founder-controlled dual-class firms prior to the IPO compared to 44 percent of VC-controlled dual-class firms, and 43 percent of the VC-backed IPOs of firms with a single class of stocks. This suggests that founder control through the dual-class structure is not likely to result from founders' power in rounds before the IPO.

Finally, in unreported tests, we examine whether bargaining power when the firm receives its first VC financing round is likely to increase the probability of a dual-class structure. We repeat the analysis presented in Table VI, but control for the amount of aggregate VC financing invested in startups located in the state where each firm is headquartered in the year the firm receives its first early-stage VC financing round (or alternatively, the year of the first financing round). We focus on $\mathrm{VC}$ financing where the startup is located because when the firm is still in relatively early stages, VC financing at the state level is likely to affect entrepreneurs' bargaining power. We also repeat this analysis, using the value of the assets of state and local pension funds weighted by the fraction of state officials on their board of trustees as in Hochberg and Rauh (2013); Ewens and Farre-Mensa (2020); González-Uribe (2020) as an instrument for the VC financing at the state level. Across all of these analyses, we find no evidence of a relationship between VC financing at the state level and the probability of dual-class structure.

Overall, the above analyses suggest that historical bargaining power in years before the IPO does not appear to predict dual-class structures at the IPO stage in the same manner that proxies for contemporaneous founder bargaining power do. 


\section{Instrumental Variable Analysis}

The controls for hot public markets discussed above suggest that the measures of venture capital financing are not merely a reflection of broader correlated economic conditions. Nevertheless, we further address the concern that our proxies for founder bargaining power that are based on high levels of available VC financing are driven by overall economic conditions by employing an instrumental variable analysis. As an instrument for industry venture capital financing, we construct a measure for supply-shifters in the amount of $\mathrm{VC}$ financing at the industry level, using changes to $\mathrm{VC}$ investment at the regional level. The rationale for the instrument is that historical shocks to the regional supply of VC investment could increase investment flows to specific industries, but are unlikely to be correlated with firms' governance structures at the IPO level. This instrument is in the spirit of shift-share IVs, which have been used in many studies in various fields of economics.

Our instrument (denoted $I V_{j, t}$ ) is based on local shifts in the amounts of VC financing weighted by the share of a given industry in local activity. Accordingly,

$$
I V_{j, t}=\sum_{r=1}^{R} z_{j, r, t-5} g_{r, t}
$$

where $z_{j, r, t-5}$ is the industry $j$ share of $\mathrm{VC}$ financing provided to companies located in region $r$ in period $t-5$, and $g_{r, t}$ is the change in $\mathrm{VC}$ financing in region $r$ from period $t-5$ to $t$. For the purpose of computing $g_{r, t}$, we measure $\mathrm{VC}$ financing in region $r$ on a five-year rolling basis. The classification into regions is based on the location of each firm that receives VC financing in the VentureXpert database. We divide the US into nine regions based on the U.S. Census region classification: New England, the Middle Atlantic, the South Atlantic, East

South Central, West South Central, East North Central, West North Central, the Mountain region, and West Pacific. We measure financing at the regional level rather than state level (a) to mitigate the potential concerns that the industry shifts are driven predominantly by one state, primarily California, and (b) to account for shocks that affect neighboring states.

The results are depicted in Table VII. Consistent with the main results, the coefficient on $V C$ Ind. Financing is significantly positive in the full sample (columns 1-4). The F-statistic is at least 78 in all specifications, and thus the instrument strongly predicts the endogenous variable. We note that the magnitudes in the instrumental variable analysis are very similar to the equivalent coefficients in Table II and Table III.

To further address the concern that the results are driven by shocks to financing in 
entrepreneurial states, we run the same regressions, but omit all firms located in California, Massachusetts, and New York. The results are in columns 5-8. Interestingly, the results for founder control and wedge are even stronger than in the specifications that include all IPOs. For example, a one standard deviation increase in VC Ind. Financing is associated with about 5.65 percent higher probability of founder control.

\section{Trends Over Time}

\section{A. Descriptive Findings}

The above analysis shows that the increase in founders' bargaining power is associated with an increase in the probability of dual-class structures, particularly for firms controlled by founders. While this association persists in different subsamples, such as non-VC-backed IPOs and non-Cloud industries, the large increase in dual-class firms in recent years may nonetheless be driven primarily by specific types of IPOs. As discussed above, three possible trends may be contributing to the rise of dual-class stocks. First, VC firms may have become more tolerant of founders' control, in large part because founders have stronger bargaining power and VC monitoring has been on the decline. Second, firms in Cloud industries now require less capital due to the introduction of Amazon Cloud computing, and therefore the bargaining power of VCs that seek to invest in these firms has eroded. Finally, there has been a gradual increase in IPOs of foreign-based firms, and these firms tend to be foundercontrolled. Indeed, as shown in Figure 2, there has been an ongoing increase in the percentage of dual-class firms among VC-backed IPOs and foreign firms, and these increases are mostly due to firms that belong to Cloud industries.

To further explore these trends, we document changes over time by the type of controller in dual-class structures in some detail. In Figure 5 through Figure 8, we split the sample into IPOs that occurred in 2005 or before and those that took place in 2006 to 2019. As can be seen from Panel A of Figure 5, much of the increase in dual-class firms is due to three groups of controllers: founders, VC firms, or founders and VC firms controlling the firm together. The likelihood of founder control in IPO firms has approximately doubled, despite the fact that VCs rarely held controlling stakes in IPO firms prior to 2006. We emphasize however that in virtually all VC-controlled firms (whether or not the control is joint with the founder), the founders' wedge is positive. Clearly, in some firms, VCs manage to maintain control and to balance the founders' interest. Presumably, the VCs seek to continue to monitor the firm and the founder after the IPO, but only until the VC unloads its stake within a year or so 
of the IPO, after which the founder alone controls the firm via dual-class structure.

In Panel $\mathrm{C}$, we observe that the increase in founder-controlled dual-class structures is extreme and dramatic among foreign firms (from 3.39 percent to 22.36 percent of all foreign IPOs). The increase in founder control among US firms is actually much smaller (from 3.26 percent to 4.34 percent of all US IPOs). Foreign and US IPOs also experienced an increase in VC-controlled dual-class firms, though among foreign firms, control tends to be shared with the founder. Foreign IPOs also experienced some increase in company-controlled dual-class firms.

Next, in Panel D, we show that in Cloud industries, there has been a dramatic increase in founder-controlled IPOs (from 3.26 percent to 14.29 percent) as well as VC-controlled IPOs (from 0.02 percent to 3.27 percent). Interestingly, in non-Cloud industries, founder control actually decreased and VC control slightly increased.

Finally, in Panel E, we show that the probability of dual-class structure, and founder control in particular, has declined in media firms. This is partly because the number of media IPOs in the latter period has been very small (see Figure 1). Additionally, we note that there have been relatively small changes in other categories, such as control by parent and holding companies, and they remain mostly stable in these various subsamples (the only exception consists of foreign firms, where there has been some increase since 2006).

Figure 6 further splits IPOs into multiple groups and periods. Panel A shows trends in Cloud industries and Panel B shows trends for other firms. In Panel A1, we observe that the trend upward in founder and VC control in VC-backed IPOs over time is more substantial than that in the non-VC-backed group. In Panel B1 on the other hand, there is no similar trend. Interestingly, in VC-backed firms in non-Cloud industries, the main increase is in VCcontrolled firms. In Panel A2, we see again the dramatic increase in founder control among foreign firms (more than 30 percent of foreign IPOs in Cloud industries) as well as VC and company control. There is a lower but sizable trend in founder and VC control among US firms. As shown in Panel B2, there is an increase in founder control in foreign IPOs even in non-Cloud industries, though much smaller than in Cloud industries. Interestingly, in non-Cloud US firms, there is actually a decline in founder control and an increase in VC control.

Next, we evaluate trends in the size of the main types of wedges among dual-class firms only. The results are presented graphically in Figure 7. In Panel A, we observe that there has been an increase in the average founders' wedge, which seems to drive the increase in the average wedge of directors and officers, since founders typically also serve on boards of 
directors. There is also an increase in the magnitude of the average public wedge (here for ease of exposition we multiply our standard definition of wedge (voting rights minus economic rights) by -1 , since the public wedge is typically negative). We observe similar trends in most groups, although the upward trend in founder wedge is particularly strong for VC-backed IPOs, foreign firms and firms in Cloud industries. Among media firms, again, we observe a decline in founders' wedge, confirming the notion that media firms are no longer a predictor of dual-class firms as in older sample periods (Gompers et al., 2009).

Finally, in Figure 8, we again split firms into Cloud and non-Cloud industries and into subgroups. The trends in wedge size in Cloud industries are quite similar to those in nonCloud industries, though for some sub-groups, we observe slightly stronger trends toward greater founder wedge (and therefore also the wedge of directors and officers). For example, the average founder wedge in VC-backed or foreign Cloud firms increased to over 20 percent in 2016-2019, whereas the average for the VC-backed or foreign non-Cloud firm is about 15 percent in the same period.

\section{B. Difference-in Differences Analysis}

We explore these patterns more formally using a difference-in-differences regression analysis surrounding the introduction of cloud computing. To the specifications outlined in Equation (4) and Equation (5), we add Post - 2005, a variable that equals one if the IPO's year is 2006 or later, following the introduction of the cloud, and interaction terms between Post-2005 and each of VC-backed, Cloud Ind. and Foreign. In additional specifications, we create a triple-difference-in-differences design by interacting $V C$-backed with Cloud Ind and Post - 2005, and Foreign with Cloud Ind and Post - 2005.

The results are presented in Table VIII. As shown in column 1, VC-backed IPOs post2005 were 10 percent more likely to be dual-class than other IPOs. Interestingly, prior to 2006, VC-backed IPOs were about 4.19 percent less likely to have a dual-class structure. Column (2) suggests that some of this post-2005 effect is due to Cloud industries, although the triple interaction on $V C$ - backed with Cloud Ind and Post - 2005 is not statistically significant. In column (3), we observe similar trends for founder control; that is, a negative association with $V C$-backed before 2006, and a positive association post-2005. However, as can be seen in column (4), this trend is mostly due to Cloud industries - VC-backed IPO firms in a Cloud industry are almost 10 percentage points more likely to be controlled by founders. We observe similar estimates when the dependent variable is public wedge (columns (5)-(6)) or founder wedge (columns (7)-(8)), except that here the decline in public 
wedge for VC-backed IPOs in the Cloud industry post-2005 (column (6)), which amounts to 1.92 percent, is statistically significant. Likewise, the same coefficient for founder wedge is 1.65 percent. These results are consistent with the view that VC firms have become much more amenable over the years to founders maintaining control of their portfolio companies, particularly in the software and services industries.

We observe similar trends with respect to foreign firms. The interactions with Post-2005 are all economically and statistically significant and point to the rise of dual-class structure and founder control post-2005. Moreover, the triple interactions are also strong, and show that the rise of dual-class structures among foreign firms is in large part due to firms in the Cloud industries. Strikingly, foreign firms in Cloud industries are 17.8 percent more likely to be controlled by founders post-2005 (column (4)).

Likewise, as hypothesized, Cloud industries experienced an increase in dual-class structures and founder control post-2005. The triple-difference-in-differences analysis, however, suggests that the rise in founder control post-2005 is driven by VC-backed IPOs and foreign firms (columns (4) and (8)).

Finally, we note that as expected, there has been a decrease in dual-class firms among media firms post-2005.

\section{Discussion}

Overall, the estimates presented above are consistent with the hypothesis that the bargaining power of VC firms vis-à-vis founders and insiders has declined, particularly in Cloud industries and foreign firms, and that, as a result, we observe more dual-class and foundercontrolled firms in recent years.

Our findings may also be consistent with a different hypothesis. It is possible that following the successful Google IPO in 2004, VC firms changed their attitudes toward dualclass stocks and formed the view that they are not harmful to shareholder value. This is consistent with recent findings that in the years after the IPO, dual-class firms outperform non-dual-class firms (Cremers et al., 2018; Kim and Michaely, 2019). Because VC firms typically sell or distribute their equity stakes after the lock-up period, the aversion toward dual-class structure may have waned in recent years. We cannot entirely rule out this hypothesis, but it is not mutually exclusive with the bargaining hypothesis that we advance in this article. It may well be that both factors have contributed to the dramatic rise in dual-class IPOs.

However, we find further support for the bargaining power hypothesis by exploring 
whether the introduction of cloud computing led to a decrease in the ongoing costs of doing business for more mature startups approaching the IPO stage. That is, we seek to examine whether the costs of running a business have become lower not only for early-stage startups (as shown by Ewens et al. (2018)), but also for firms at the IPO stage. Thus, we construct two variables that capture the costs of doing business: Costs of Goods defined as the costs of goods divided by sales in the fiscal year prior to the IPO, and General Expenses defined as selling, general and administrative expenses divided by sales in the fiscal year prior to the IPO. ${ }^{29}$ We then employ a difference-in-differences analysis to examine whether these costs have decreased in our sample for treated firms after 2005 and the introduction of cloud computing.

The results in Table IX provide evidence that there has been a substantial decrease after 2005 in both cost measures. This decrease is economically meaningful: the mean of the Costs of Goods variable is 0.61, while the marginal effect for treated firms post-2005 ranges from -0.070 to -0.082. The mean General Expenses is 0.48, and the effect on treated firms after 2005 is between -0.06 and -0.13 . The estimates suggest that the ongoing capital needs of treated firms have generally declined since the introduction of cloud computing, and that, therefore, their success has likely become less dependent on obtaining funding from VC firms. Overall, our results are consistent with the notion that the change in VCs' attitudes toward dual-class structures may be at least partly the result of their weaker bargaining position following technological changes that reduced entrepreneurs' costs of doing business.

\section{Sunset Provisions}

While an IPO firm may have a dual-class structure in place at the time it goes public, such structures need not be permanent, and often have pre-determined end points, or "sunset provisions." Sunsets specify circumstances under which the superior and inferior voting shares convert into a common class of common stock, and the dual-class structure ceases to exist. As discussed in Section III.D, we identify four type of sunset provisions: time sunsets, ownership sunsets, transfer sunsets and other sunsets.

There has been a vigorous policy debate over the need for sunsets to prevent insiders in dual-class firms from controlling the companies in perpetuity. The debate has focused mainly on time sunsets that terminate the dual-class structure after a specified period (e.g., ten years). On one hand, such sunsets address the concern that the vision and skills of con-

\footnotetext{
${ }^{29}$ To mitigate the effect of outliers on our analysis, we omit firms with sales that are lower than $\$ 5$ million.
} 
trollers will dissipate over time (Bebchuk and Kastiel, 2017). On the other hand, it is likely impossible to predict at the time of the IPO when founders' skill and motivation will decline. Accordingly, some highlight the advantages of ownership sunsets that essentially convert the firm into a single class firm when the controller' economic interest falls below a certain threshold (Fisch and Solomon, 2019; Sharfman, 2019). The disadvantage of this approach, however, is that it does not guarantee that the controllers' power will be terminated.

In Figure 9 we show by controller the percentage of dual-class firms that adopt each type of sunset provision. As shown in Panel A, time sunsets are relatively rare in foundercontrolled firms. Thus, it is possible that founders resist provisions that take away their control after a few years. On the other hand, when control is shared with a VC firm, 40 percent of firms adopt such sunsets. Adoption rates are even higher when a VC firm has exclusive control of the firm. This is consistent with the idea that adoption of time sunsets is the product of negotiation between founders and VC firms, and demonstrates VCs' role in monitoring insiders.

As shown in Panel B, ownership sunsets are adopted more frequently across different types of controllers. But we observe a similar pattern of adoption in founder or VC-controlled firms. Adoption rates in founder-controlled firms are relatively low, but are higher when control is shared with a VC firm, and even higher in firms controlled exclusively a VC firm.

Transfer sunsets as shown in Panel $\mathrm{C}$ are frequent in founder-controlled firms with more than 60 percent adopting them, likely because when founders transfer their interests, the justification for a dual-class structure to preserve founder visions is weak. Interestingly, in Panel D, we do not observe a high percentage of sunsets that terminate dual-class structures in other events that include events such as the death or disability of the founders. But again, the percentage of these sunsets is higher when a VC firm has control of the firm.

In Figure 10, we explore trends over time by comparing dual-class firms exclusively controlled by founders to all other dual-class firms. First, we observe that there is an overall trend towards adopting all types of sunset provisions. The trend is similar in foundercontrolled firms and other firms, with one notable exception. The increase in the percentage of time sunsets is much smaller in founder-controlled firms than in other firms. Thus, the increase in founders' bargaining power may permit them to resist time sunsets, despite a growing expectation that dual-class firms will adopt them.

We hypothesize that when a founder's bargaining position is stronger, the firm is less likely to adopt sunsets. As in Section V.B, we use a difference-in-differences analysis by exploiting the introduction of cloud computing as a shock to founders' bargaining power. To make the 
interpretation of the coefficients easier, we interact Founder - control with Post - 2005 and Non-Cloud, an indicator equal to one if the firm does not belong to a Cloud industry. In this way, the coefficient of interest is the interaction between Founder - control and Post -2005.

The results are presented in Table X. As shown in column 1, founder control is associated with a 16.2 percent lower likelihood of time sunsets and a 17.6 lower likelihood of adopting ownership sunsets. This suggests that founders' bargaining power permits them to avoid sunsets that curb their control. Moreover, if the IPO is VC-backed it is 6.6 percent more likely to have a time sunset, but not other sunsets. Overall, our findings regarding sunsets further reinforce our hypothesis that the changing bargaining relationship between founders and VCs affects the prevalence of dual-class structures.

\section{Shareholder Value}

Our last set of analyses examine the association of different types of wedges to IPO valuations. We use two principal measures. The first is Tobin's Q, defined as market value of equity plus book value of assets minus book value of equity divided by book value of assets. Book equity is defined as in (Fama and French, 1992), market value of equity is defined as the fiscal year end close price times the number of shares outstanding as of the first fiscal year following the IPO, and book assets is defined as the most recent book assets following the IPO date. The second is the price-to-book ratio, defined as the ratio of the market value of equity divided by book equity as of the first fiscal year end following the IPO. We winsorize both measures at the 2.5 percent level.

Table XI presents the results from regressions where Tobin's Q is the dependent variable. In column (1), we estimate a model that relates the size of the founder's wedge to Tobin's Q, including industry (two-digit SIC code) and year fixed effects. In column (2), we add the squared founder's wedge to allow for a possible non-linear relationship with Tobin's Q. In column (3), we substitute the fixed effects with industry-year fixed effects to account for possible industry-year shocks (e.g., industry business cycle). In column (4), we add three more wedges, (i) public wedge, (ii) directors and officers (D\&O) wedge, and (iii) company wedge. Finally, in column (5), we add firm-level control variables, including the logarithm of the company age, the logarithm of the total assets, the logarithm of the economic value of the patents filed for by the IPO firm before the IPO (in $\$$ millions), firm's leverage, cash-to-total assets ratio and two indicators for whether the firm has positive or missing R\&D expenses. 
Table XII presents results from identical specifications, except that the dependent variable is price-to-book ratio.

Overall, the estimates indicate a robust positive relationship between the founder's wedge and Tobin's Q. For example, based on the estimates in column (3), a one standard deviation increase in the founder's wedge (7.09 percent) is associated with a 10.6 percent increase in Tobin's Q. We emphasize however that the increase in $\mathrm{Q}$ is at a decreasing rate, as the coefficient on the squared founder's wedge is negative. Based on column (3), if the wedge exceeds 52.6 percent, the association between the founder's wedge and Tobin's Q is negative. We find qualitatively similar results when the dependent variable is price-to-book ratio (although the estimates are less statistically significant in column 5). Based on column (3), a one standard deviation increase in the founder's wedge is associated with a 8.73 percent higher price-to-book ratio.

These estimates are consistent with the notion that the IPO value of founder-controlled firms is higher than that of other firms. Public investors seem to place a high value on the visions and commitment of founders to the firm. When founders have extreme control and little economic interest, however, the market may be concerned that the founder has limited incentives to exert efforts. Interestingly, we do not find any statistically significant associations with other wedges that are robust across specifications. In particular, the wedge of public shareholders is not significantly correlated with shareholder value in any specification. These results cast doubt on the notion that the market views dual-class firm structures on average as imposing agency costs (Lund, 2019).

\section{Conclusion}

Although many studies have evaluated the consequences of dual-class structures for firm performance, few studies have carefully examined the determinants of these structures and the size of the wedge between insiders' voting power and cashflow rights. Understanding the factors that predict dual-class structures is increasingly important in light of the dramatic rise in dual-class IPOs and the general concerns that these structures present agency problems for investors.

Our paper is the first to explore the different types of dual-class firms in a large sample of over 5,000 IPOs between 1994-2019. Founders control many of them, but others are controlled by corporations, investment firms or families. We demonstrate that the rise of dual-class structures is mainly due to founder-controlled firms in the software and services 
industries and foreign-based firms. We show that the main factor that predicts dual-class structures and a greater wedge is the amount of available private financing for startups. The more outside opportunities the founders have, the greater their bargaining power when raising capital. Therefore, they are better able to retain control of the firm after the IPO. We also document a decrease in VC firms' aversion to dual-class structures and attribute it-at least in part-to the reduction in the costs of doing business due to technological advances in the software and service industries. This finding is consistent with the idea that when there is a lower need for financing, founders are less likely to relinquish their power to VC firms (Ewens, Nanda, and Rhodes-Kropf, 2018; Ewens and Malenko, 2020).

Our study has important implications for understanding the evolving nature of public markets. The literature to date has shown that increases in private financing have led to a decrease in the number of firms in public markets, and therefore more concentrated ownership in the economy as a whole (Ewens and Farre-Mensa, 2020). We further show that greater private financing may also cause public markets themselves to change by allowing founders to retain greater power to pursue their visions, without keeping an economic stake in the firm.

Our findings provide critical input for evaluating policy proposals that affect the nature of public and private markets. They suggest that policies to liberalize private markets by loosening the restrictions on selling and trading in private securities (SEC, 2019) may not only make public issuances less desirable, but may also increase the likelihood that the firms that do ultimately go public will be controlled by their founders. While our analysis suggests that public markets attach higher valuations to founder-controlled firms as compared to other IPO firms, the broader ramifications of a growing number of controlled public firms in a shrinking public market require further analysis.

Finally, the realization that dual-class stock refers to an array of ownership arrangements, ranging from control by a visionary founder to a holding company or a family, should lead to a rethinking of corporate governance research on the effects of dual-class structures. As our results on innovation and valuations demonstrate, the type of controller and wedge between economic and voting rights may be associated with different outcomes. 


\section{REFERENCES}

Adams, Renée B., and Daniel Ferreira, 2009, Women in the boardroom and their impact on governance and performance, Journal of Financial Economics 94, 291-309.

Alden, William, 2014, Venture capitalists coddle entrepreneurs as royalty, The New York Times.

Alon-Beck, Anat, 2019, The new unicorn investors-disruptors or distractors?, Working paper

Baker, Malcolm, and Paul A Gompers, 2003, The determinants of board structure at the initial public offering, Journal of Law and Economics 46, 569-598.

Balasubramanian, Natarajan, and Jagadeesh Sivadasan, 2011, What happens when firms patent? new evidence from u.s. economic census data, Review of Economics and Statistics 93, 126-146.

Barrot, Jean-Noël, 2016, Investor horizon and the life cycle of innovative firms: Evidence from venture capital, Management Science 63, 3021-3043.

Barry, Christopher B, Chris J Muscarella, John W Peavy III, and Michael R Vetsuypens, 1990, The role of venture capital in the creation of public companies: Evidence from the going-public process, Journal of Financial Economics 27, 447-471.

Bebchuk, Lucian A, and Kobi Kastiel, 2017, The untenable case for perpetual dual-class stock, Virginia Law Review 103, 585.

Black, Bernard S, and Ronald J Gilson, 1998, Venture capital and the structure of capital markets: banks versus stock markets, Journal of Financial Economics 47, 243-277.

Bloomberg, 2019, China approves first dual-class ipo in bid to lure tech firms .

Broughman, Brian J, and Jesse M Fried, 2020, Do founders control start-up firms that go public?, Harvard Business Law Review 10, 49-86.

Catan, Emiliano M., 2019, The insignificance of clear-day poison pills, Journal of Legal Studies 48, 1-44.

Choi, Albert H., 2018, Concentrated ownership and long-term shareholder value, Harvard Business Law Review 8, 53-99.

Claessens, Stijn, Simeon Djankov, Joseph Fan, and Larry Lang, 2002, Disentangling the incentive and entrenchment effects of large shareholdings, Journal of Finance 57, 27412771.

Claessens, Stijn, Simeon Djankov, and Larry Lang, 2000, The separation of ownership and control in east asian corporations, Journal of Financial Economics 58, 81-112. 
Cornett, Marcia Millon, and Michael R Vetsuypens, 1989, Voting rights and shareholder wealth the issuance of limited voting common stock, Managerial and Decision Economics $10,175-188$.

Cremers, K.J. Martijn, and Yaniv Grinstein, 2013, Does the market for ceo talent explain controversial ceo pay practices?, Review of Finance 18, 921-960.

Cremers, K.J. Martijn, Beni Lauterbach, and Anete Pajuste, 2018, The life-cycle of dual class firm valuation, European Corporate Governance Institute (ECGI)-Finance Working Paper.

Cremers, K.J. Martijn, Lubomir P. Litov, and Simone M. Sepe, 2017, Staggered boards and long-term firm value, revisited, Journal of Financial Economics 126, 422-444.

Daines, Robert, and Michael Klausner, 2001, Do ipo charters maximize firm value? antitakeover protection in ipos, Journal of Law, Economics, and Organization 17, 83-120.

de Fontenay, Elisabeth, 2017, The deregulation of private capital and the decline of the public company, Hastings Law Journal 68, 445.

DeAngelo, Harry, and Linda DeAngelo, 1985, Managerial ownership of voting rights: A study of public corporations with dual classes of common stock, Journal of Financial Economics 14, 33-69.

Dimitrov, Valentin, and Prem C Jain, 2006, Recapitalization of one class of common stock into dual-class: Growth and long-run stock returns, Journal of Corporate Finance 12, 342-366.

Doidge, Craig, Kathleen M Kahle, G Andrew Karolyi, and René M Stulz, 2018, Eclipse of the public corporation or eclipse of the public markets?, Journal of Applied Corporate Finance 30, 8-16.

Ewens, Michael, and Joan Farre-Mensa, 2020, The deregulation of the private equity markets and the decline in IPOs, Review of Financial Studies 33, 5463-5509.

Ewens, Michael, and Nadya Malenko, 2020, Board dynamics over the startup lifecycle, Working paper.

Ewens, Michael, Ramana Nanda, and Matthew Rhodes-Kropf, 2018, Cost of experimentation and the evolution of venture capital, Journal of Financial Economics 128, 422-442.

Fama, Eugene F, and Kenneth R French, 1992, The cross-section of expected stock returns, Journal of Finance 47, 427-465.

Field, Laura Casares, and Gordon Hanka, 2001, The expiration of ipo share lockups, the Journal of Finance 56, 471-500. 
Field, Laura Casares, and Michelle Lowry, 2017, Bucking the trend: Why do ipos choose controversial governance structures and why do investors let them, Working paper.

Fisch, Jill, and Steven Davidoff Solomon, 2019, The problem of sunsets, Boston University Law Review 99, 1057.

Fried, Jesse M., and Matthew Schoenfeld, 2020, The risky business of investing in chinese tech firms, Harvard Law School Forum on Corporate Law and Governance.

Gao, Xiaohui, Jay R. Ritter, and Zhongyan Zhu, 2013, Where have all the IPOs gone?, Journal of Financial and Quantitative Analysis 48, 1663-1692.

Gompers, Paul A., 1995, Optimal investment, monitoring, and the staging of venture capital, Journal of Finance 50, 1461-1489.

Gompers, Paul A, Joy Ishii, and Andrew Metrick, 2009, Extreme governance: An analysis of dual-class firms in the united states, The Review of Financial Studies 23, 1051-1088.

González-Uribe, Juanita, 2020, Exchanges of innovation resources inside venture capital portfolios, Journal of Financial Economics 135, 144-168.

Goshen, Zohar, and Assaf Hamdani, 2015, Corporate control and idiosyncratic vision, Yale Law Journal 125, 560.

Grossman, Sanford J., and Oliver D. Hart, 1986, The costs and benefits of ownership: A theory of vertical and lateral integration, Journal of Political Economy 94, 691-719.

Hansmann, Henry, 1988, Ownership of the firm, Journal of Law, Economics, and Organization 4, 267-304.

Hellmann, Thomas, and Manju Puri, 2002, Venture capital and the professionalization of start-up firms: Empirical evidence, Journal of Finance 57, 169-197.

Hochberg, Yael V., 2012, Venture capital and corporate governance in the newly public firm, Review of Finance 16, 429-480.

Hochberg, Yael V., Laura A. Lindsey, and Mark M. Westerfield, 2015, Resource accumulation through economic ties: Evidence from venture capital, Journal of Financial Economics $118,245-267$.

Hochberg, Yael V, and Joshua D Rauh, 2013, Local overweighting and underperformance: Evidence from limited partner private equity investments, The Review of Financial Studies 26, 403-451.

Hout, Thomas, and David Michael, 2014, A chinese approach to management, Harvard Business Review 92, 103-107. 
Iliev, Peter, and Michelle Lowry, 2020, Venturing beyond the ipo: Financing of newly public firms by pre-ipo investors, Journal of Finance 75, 1527-1577.

Jarrell, Gregg A, and Annette B Poulsen, 1988, Dual-class recapitalizations as antitakeover mechanisms: The recent evidence, Journal of Financial Economics 20, 129-152.

Jenter, Dirk, and Fadi Kanaan, 2015, Ceo turnover and relative performance evaluation, Journal of Finance 70, 2155-2184.

Kaplan, Steven N, Frederic Martel, and Per Stromberg, 2007, How do legal differences and experience affect financial contracts, Journal of Financial Intermediation 16, 273-311.

Kaplan, Steven N., and Per Stromberg, 2001, Venture capitals as principals: Contracting, screening, and monitoring, American Economic Review 91, 426-430.

Kaplan, Steven N., and Per Stromberg, 2003, Financial contracting theory meets the real world: An empirical analysis of venture capital contracts, Review of Economic Studies 70, $281-315$.

Karpoff, Jonathan, and Laura Field, 2002, Takeover defenses of ipo firms, Journal of Finance $5,1857-1889$.

Kim, Hyunseob, and Roni Michaely, 2019, Sticking around too long? dynamics of the benefits of dual-class voting, European Corporate Governance Institute (ECGI)-Finance Working Paper 19-09.

Kogan, Leonid, Dimitris Papanikolaou, Amit Seru, and Noah Stoffman, 2017, Technological innovation, resource allocation, and growth, The Quarterly Journal of Economics 132, 665-712.

Kupor, Scott, 2012, Sorry calpers, dual class shares are a founder's best friend, Forbes.

Lehn, Kenneth, Jeffry Netter, and Annette Poulsen, 1990, Consolidating corporate control: Dual-class recapitalizations versus leveraged buyouts, Journal of Financial Economics 27, $557-580$.

Lemmon, Michael L, and Karl V Lins, 2003, Ownership structure, corporate governance, and firm value: Evidence from the east asian financial crisis, Journal of Finance 58, 1445-1468.

Lerner, Josh, 1995, Venture capitalists and the oversight of private firms, Journal of Finance 50, 301-0318.

Lowry, Michelle, Roni Michaely, and Ekaterina Volkova, 2017, Initial public offerings: A

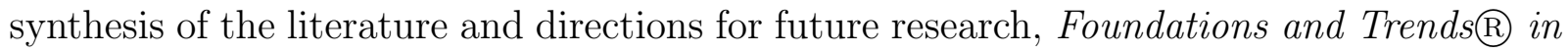
Finance 11, 154-320.

Lublin, Joann S, and Spencer E. Ante, 2012, A fight in silicon valley: Founders push for control, The Wall Street Journal. 
Lund, Dorothy, 2019, Nonvoting shares and efficient corporate governance, Stan. L. Rev. 71, 687.

Masulis, Ronald W, Cong Wang, and Fei Xie, 2009, Agency problems at dual-class companies, Journal of Finance 64, 1697-1727.

Partch, M Megan, 1987, The creation of a class of limited voting common stock and shareholder wealth, Journal of Financial Economics 18, 313-339.

Peters, Florian S, and Alexander F Wagner, 2014, The executive turnover risk premium, The Journal of Finance 69, 1529-1563.

Ritter, Jay R., 2020, Initial public offerings: Foreign companies going public in the u.s., 1980-2019 .

Schubarth, Cromwell, 2013, Ipo rocket veeva: From $\$ 7 \mathrm{~m}$ investment to $\$ 4.4 \mathrm{~b}$ company, Silicon Valley Business Journal.

SEC, 2019, Concept release on harmonization of securities offering exemptions, securities act release no. 10649, https://www.sec.gov/rules/concept/2019/33-10649.pdf.

Sharfman, Bernard S, 2019, The undesirability of mandatory time-based sunsets in dual class share structures: A reply to bebchuk and kastiel, S. Cal. L. Rev. Postscript 93, 1.

Smart, Scott B, Ramabhadran S Thirumalai, and Chad J Zutter, 2008, What's in a vote? the short-and long-run impact of dual-class equity on ipo firm values, Journal of Accounting and Economics 45, 94-115.

Smart, Scott B, and Chad J Zutter, 2003, Control as a motivation for underpricing: a comparison of dual and single-class ipos, Journal of Financial Economics 69, 85-110.

Winkler, Rolfe, and Maureen Farrell, 2018, In founder-friendly era, star tech entrepreneurs grab power, huge pay, The Wall Street Journal. 


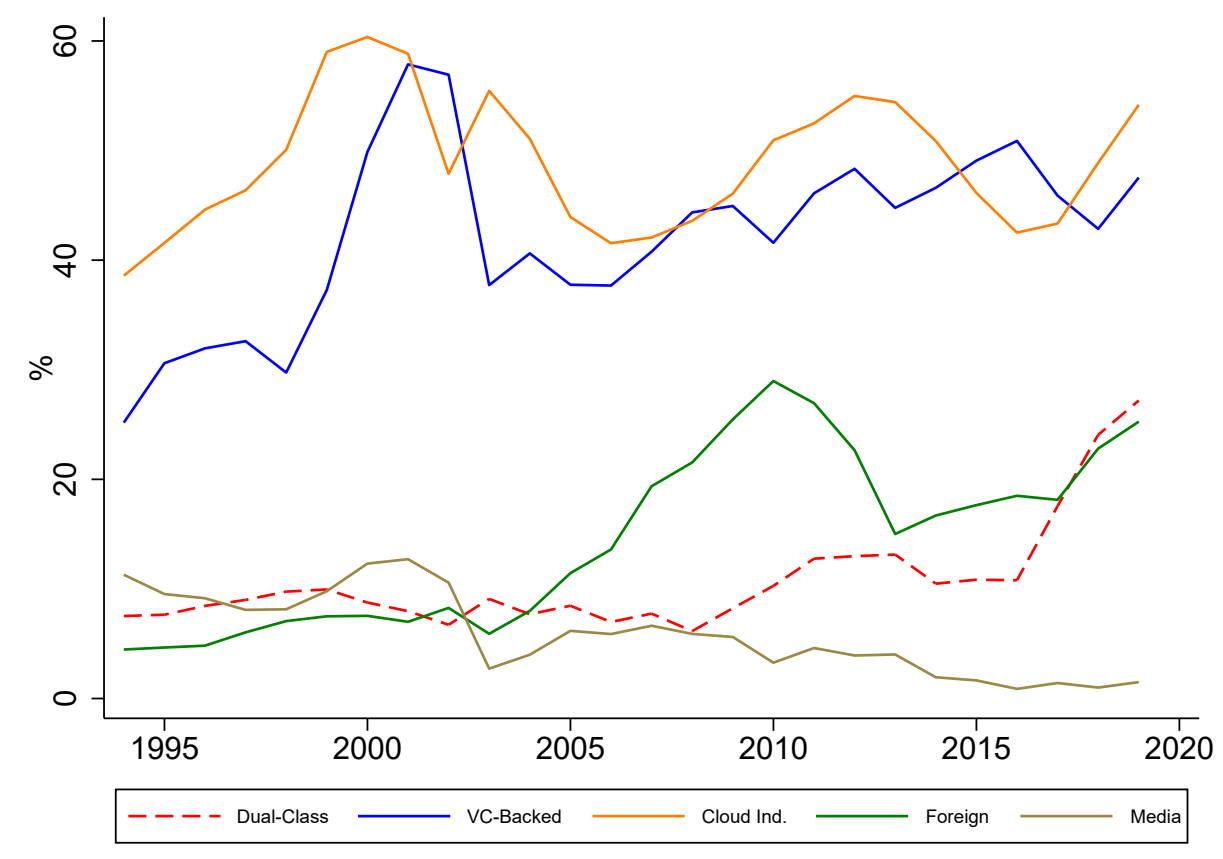

Figure 1. Trends in Initial Public Offerings. This figure shows the three-year rolling average percentage of different types of Initial Public Offerings (IPOs) out of the total number of IPOs in 1994-2019, including (a) Dual-class IPOs, (b) IPOs of VC-backed firms, (c) IPOs of firms that belong to Cloud Industries, (d) Foreign-based firms, and (e) Media companies. All categories of IPOs are described in the Appendix. 


\section{Panel A: All IPOs}

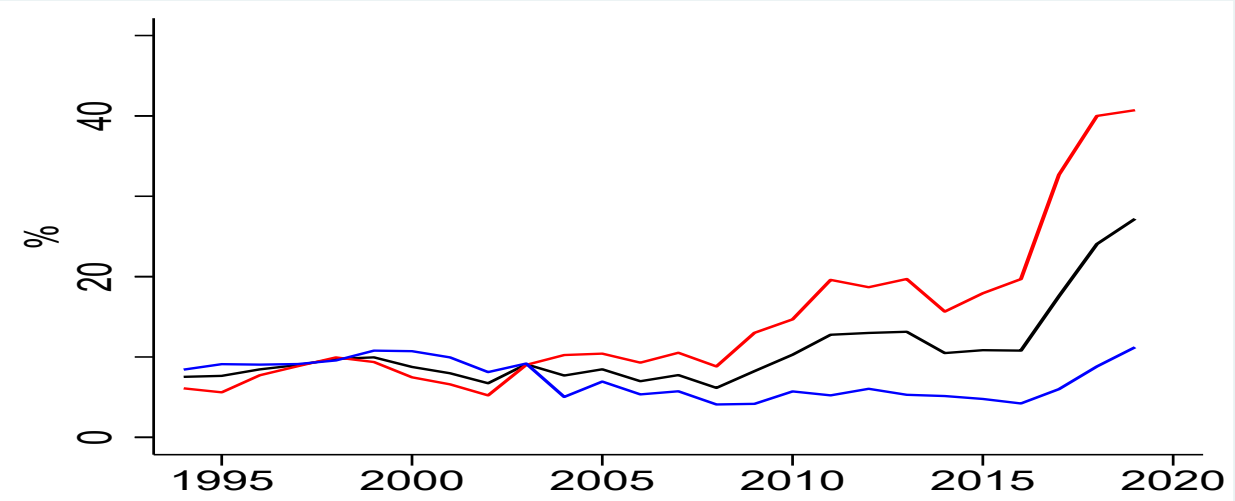

Panel B: VC-Backed IPOs

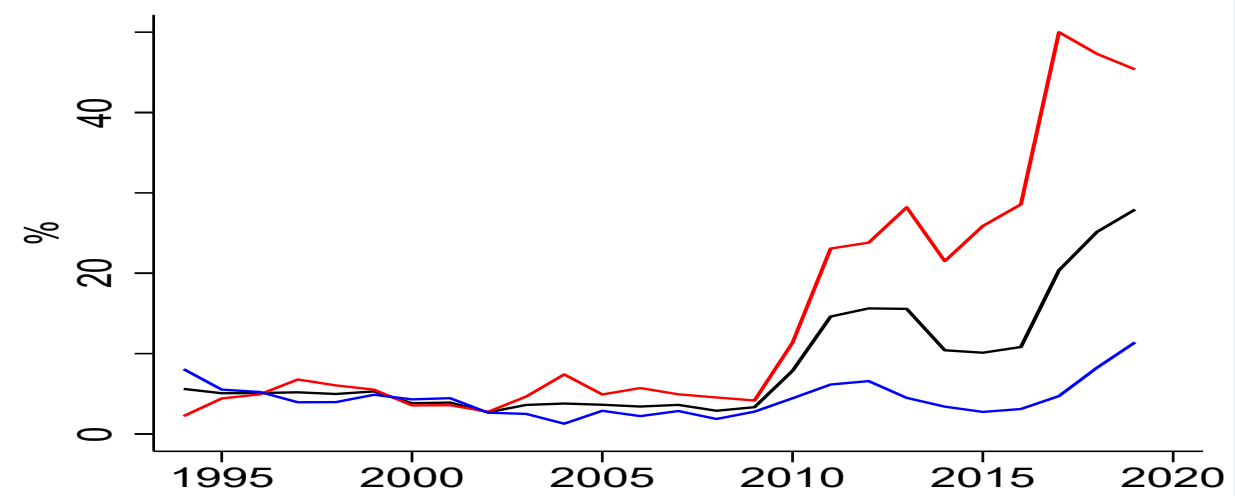

Panel C: Foreign IPOs

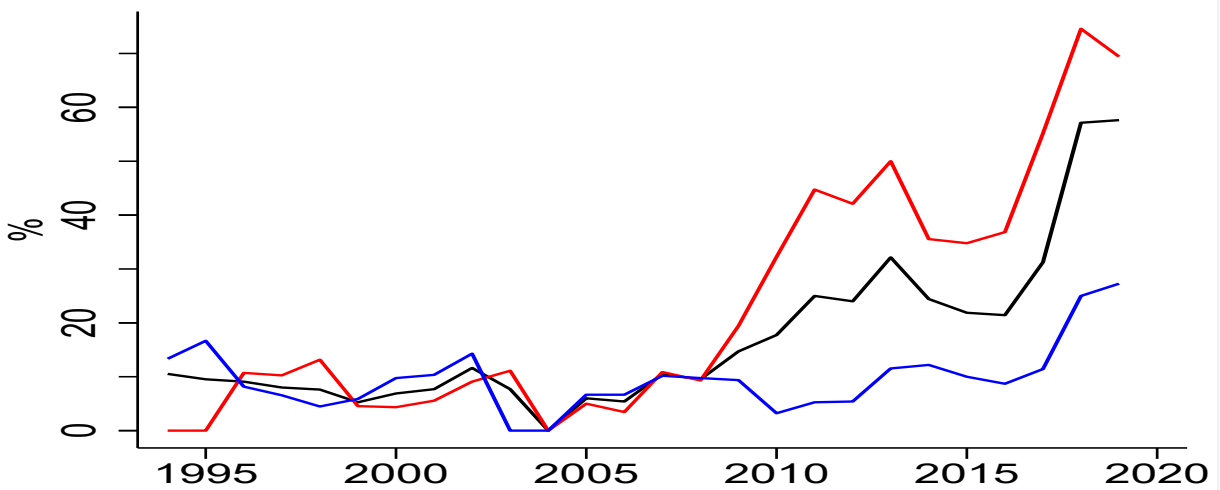

All Firms $\quad$ Cloud Ind.

Non-Cloud Ind.

Figure 2. Trends in the Probability of Dual-Class IPOs by Industry. This figure shows the three-year rolling average percentage of Dual-class IPOs out of the total number of IPOs (Panel A), the total number of VC-Backed IPOs (Panel B) and the total number of Foreign-based IPOs (Panel C). In each panel, we split the sample into IPOs of firms that belong to Cloud industries and IPOs of firms that do not belong to such industries. 


\section{Panel A: All IPOs}
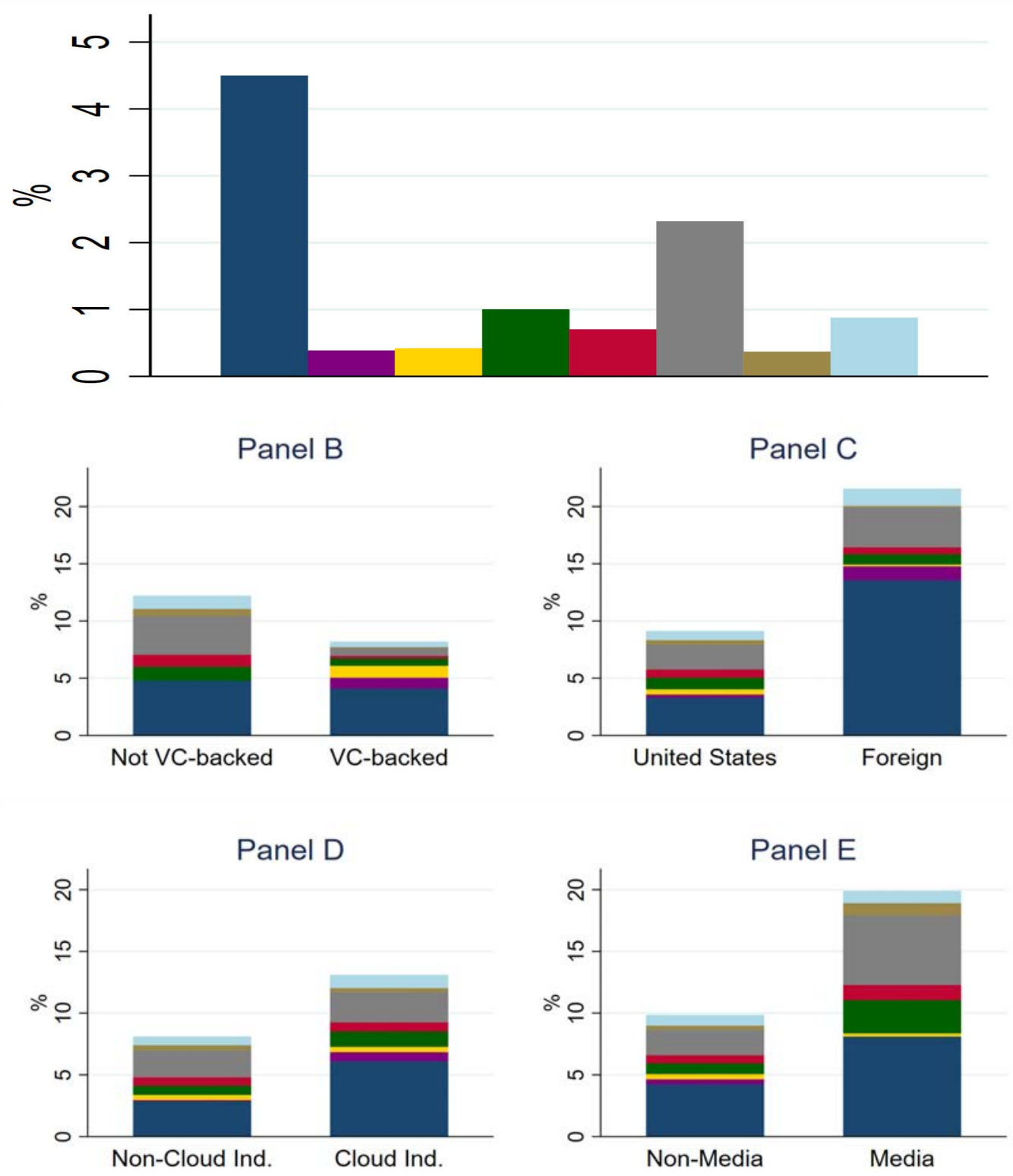

\begin{tabular}{|c|c|c|c|}
\hline Founder & Founder \& VC & Venture Capital & Private Equity \\
\hline Directors \& Officers & Company & Family & Other/None \\
\hline
\end{tabular}

Figure 3. The Percentage of Dual-Class IPOs by Controller. This figure shows the percentage of dual-class IPOs by the type of controller. Types of controllers include: Founder, Founder and Venture Capital Firm, Venture Capital Firm, Private Equity Firm, Directors \& Officers who are not founders, a Company which is a parent or holding company, a Family business, or other type of investors or no controller. Panel A includes all IPOs, Panel B divides IPOs into IPOs of VC-backed firms, and non-VC-backed firms. Panel C divides IPOs into firms located in the United States and firms located elsewhere. Panel D divides IPOs into firms that belong to Cloud industries and those in other industries. Panel E divides IPOs into non-media firms and media firms. 


\section{Panel A: Total VC Investment}

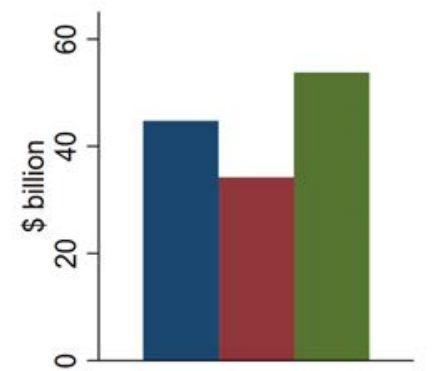

All Industries

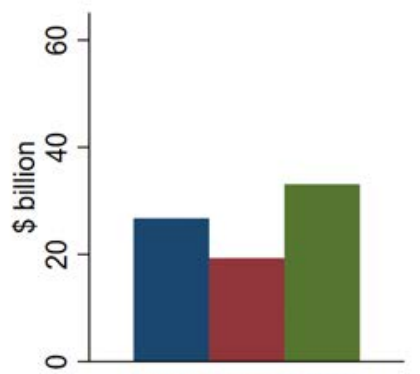

Cloud Industries

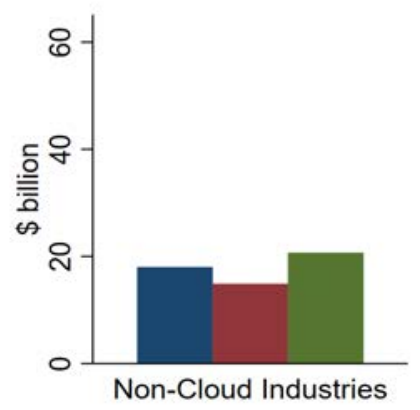

\section{Panel B: Total VC Late-Stage Investment}

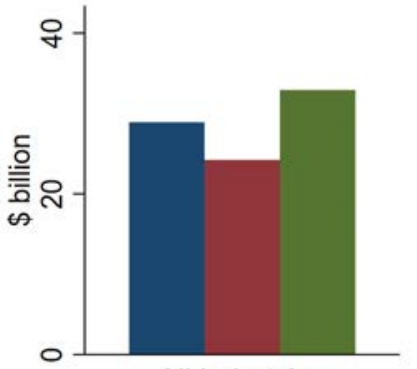

All Industries

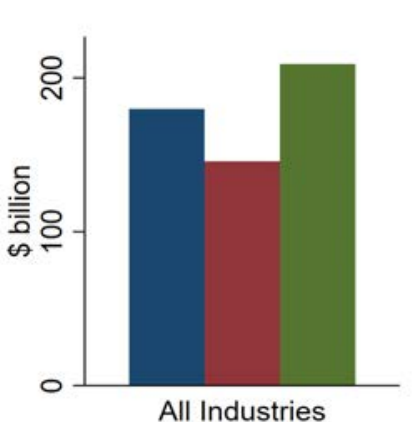

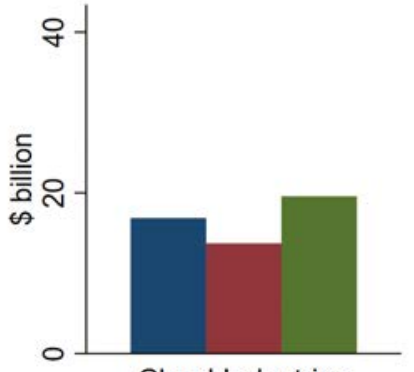

Cloud Industries
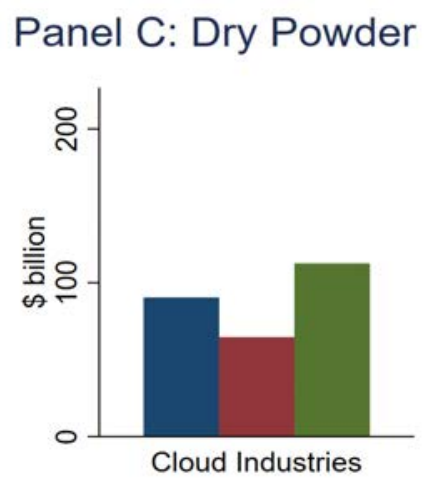
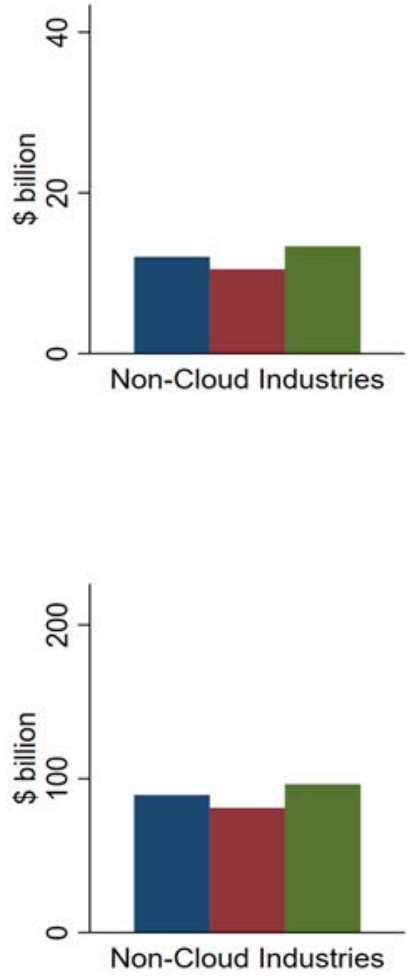

Figure 4. Trends in VC Investment. This figure shows the amount of VC investment (Panel A), Late-stage VC Investment (Panel B) and Dry Powder (Panel C) in $\$$ billions before and after 2005. In each panel, we split these amounts into funds associated with Cloud industries and non-Cloud industries. 


\section{Panel A: All IPOs}

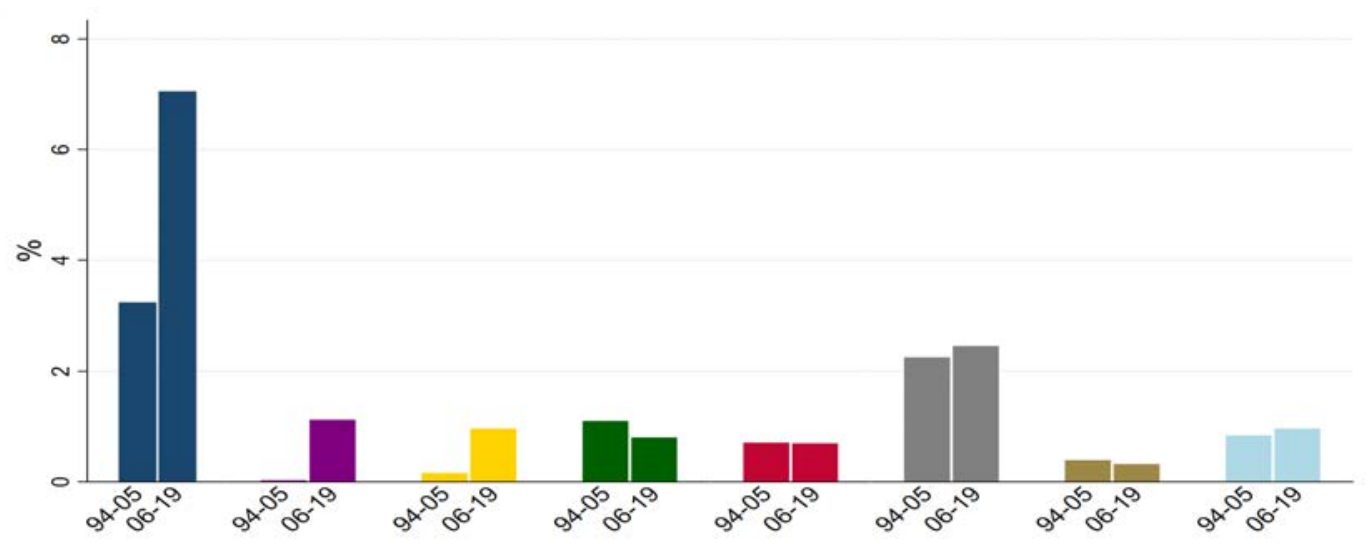

Panel B
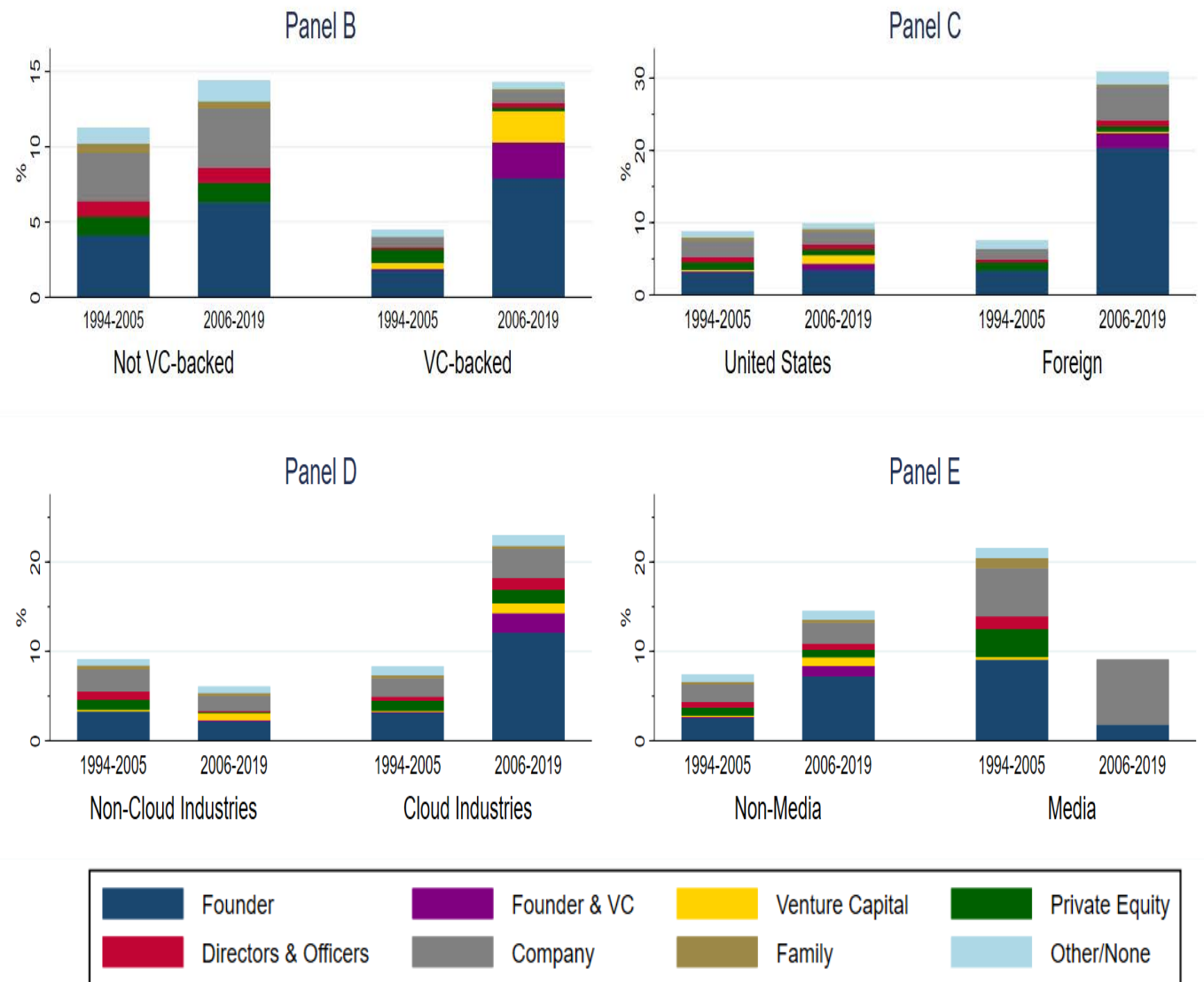

Figure 5. Trends in Dual-Class IPOs by Controller. This figure shows the percentage of dual-class IPOs by the type of controller by comparing IPOs in 1994-2005 to IPOs in 2006-2019. Types of controllers include: Founder, Founder and Venture Capital Firm, Venture Capital Firm, Private Equity Firm, Directors \& Officers who are not founders, a Company which is a parent or holding company, a Family business, or other type of investors or no controller. Panel A includes all IPOs, Panel B divides IPOs into IPOs of VC-backed firms, and non-VC-backed firms. Panel C divides IPOs into firms located in the United States and firms located elsewhere. Panel D divides IPOs into firms that belong to Cloud industries and those in other industries. Panel E divides IPOs into non-media firms and media firms. 


\section{Panel A: Trends in Cloud Industries}
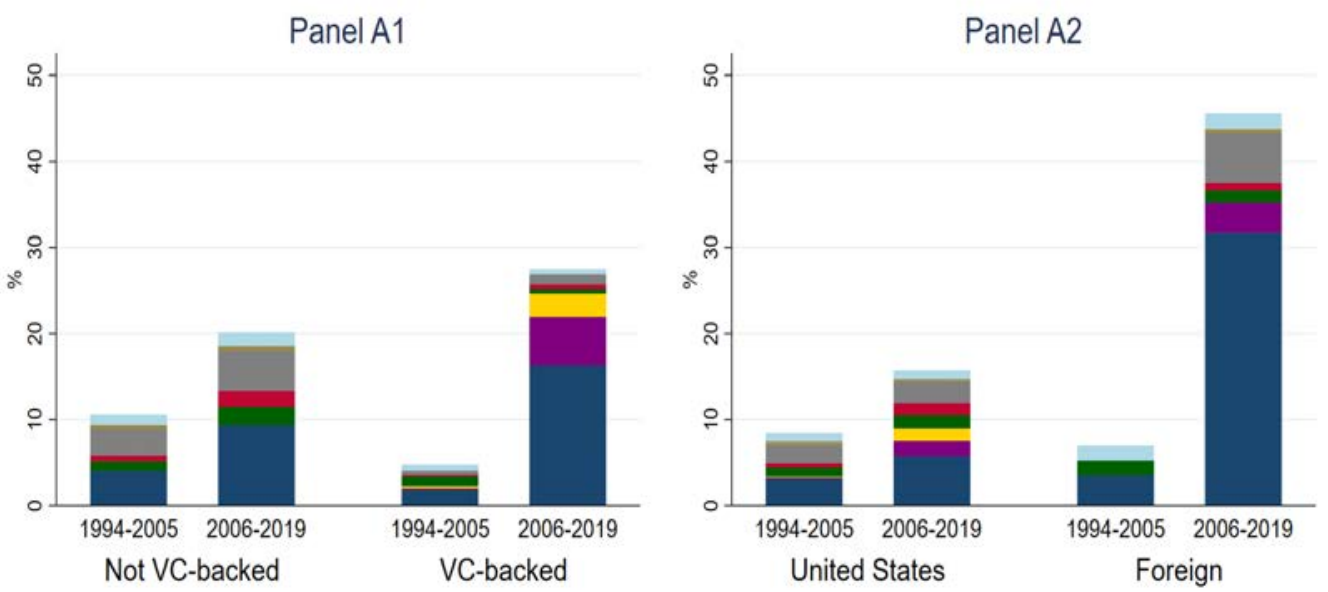

\section{Panel B: Trends in Non-Cloud Industries}
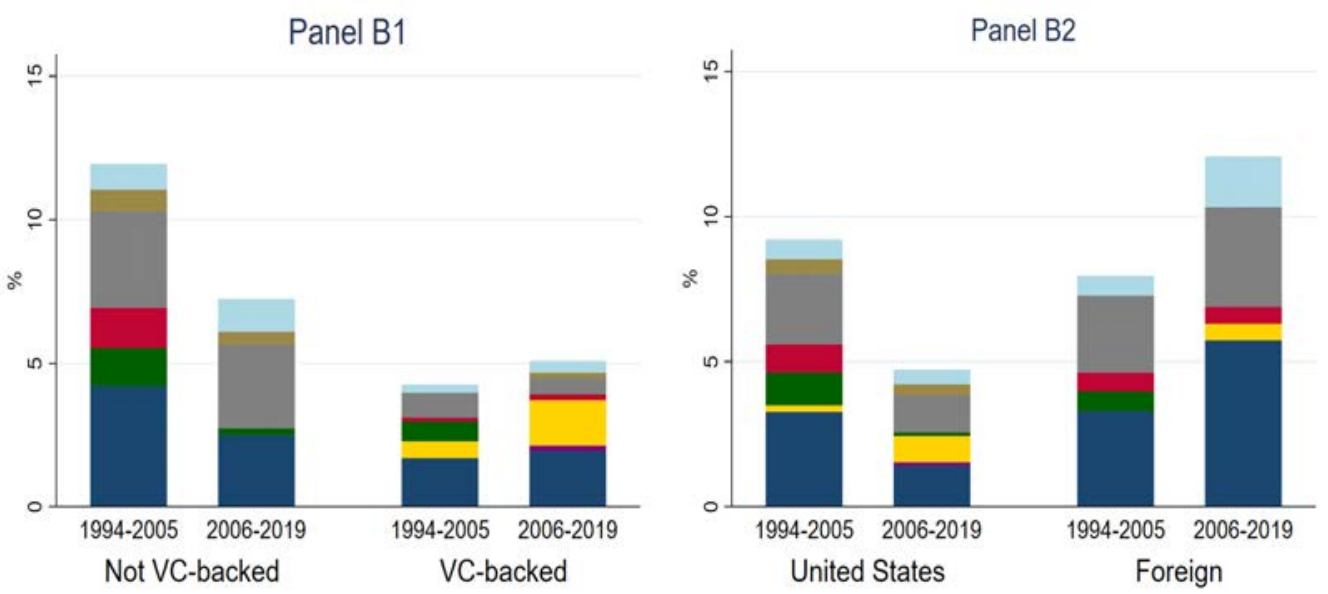

\begin{tabular}{|l|l|l|l|}
\hline Founder & Founder \& VC & Venture Capital & \\
\hline Directors \& Officers & Company & Family & Other/None \\
\hline
\end{tabular}

Figure 6. Trends in Dual-Class IPOs by Controller and Industry. This figure compares the percentage of dual-class IPOs by the type of controller in 1994-2005 to that in 2006-2019. Types of controllers include: Founder, Founder and Venture Capital Firm, Venture Capital Firm, Private Equity Firm, Directors \& Officers who are not founders, a Company which is a parent or holding company, a Family business, or other type of investors or no controller. Panel A includes all IPOs of firms in Cloud Industries, and Panel B includes all IPOs of firms in other industries. Each Panel divides IPOs into IPOs of VC-backed firms, and non-VC-backed firms and firms located in the United States and firms located elsewhere. 


\section{Panel A: All IPOs}
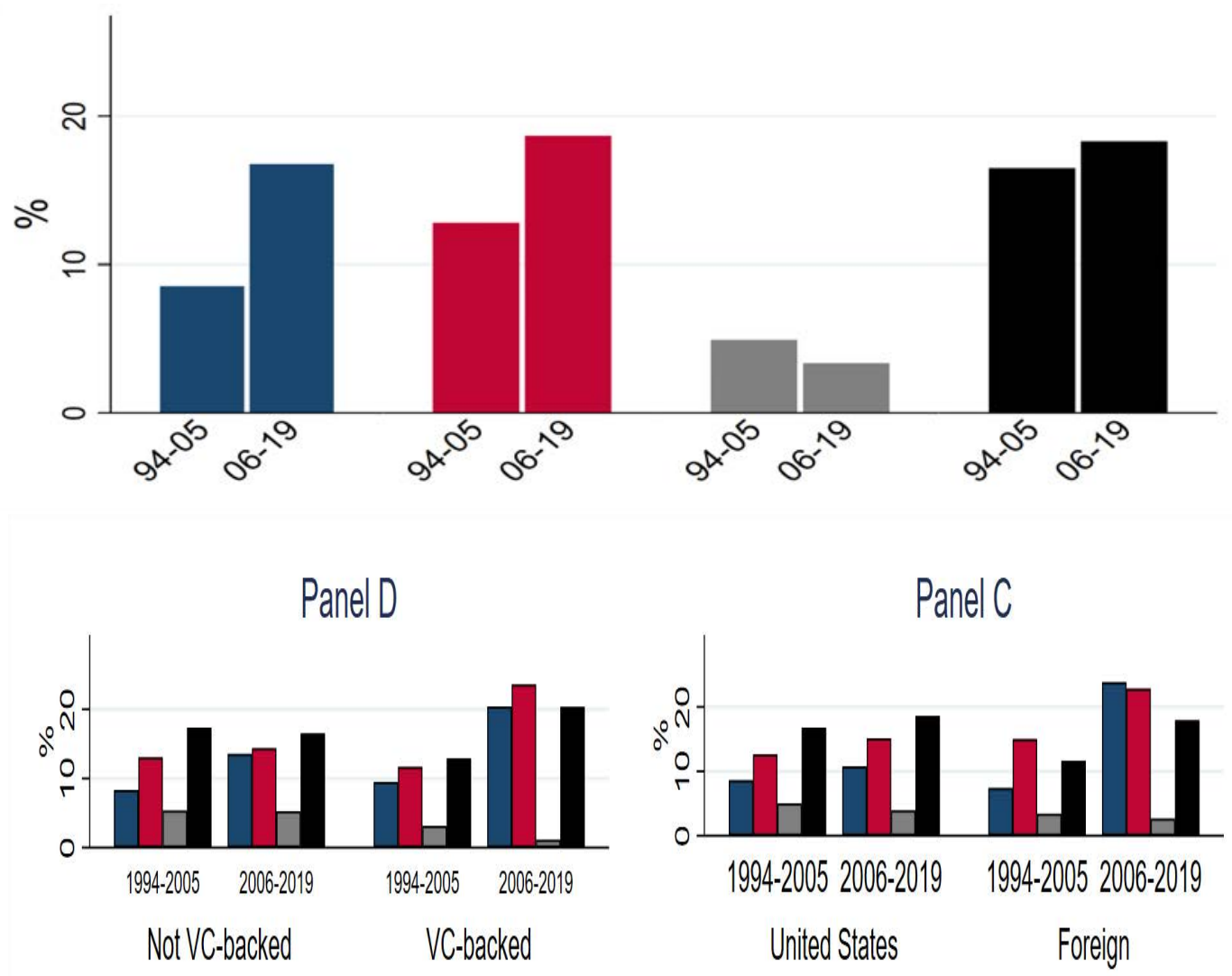

Panel B
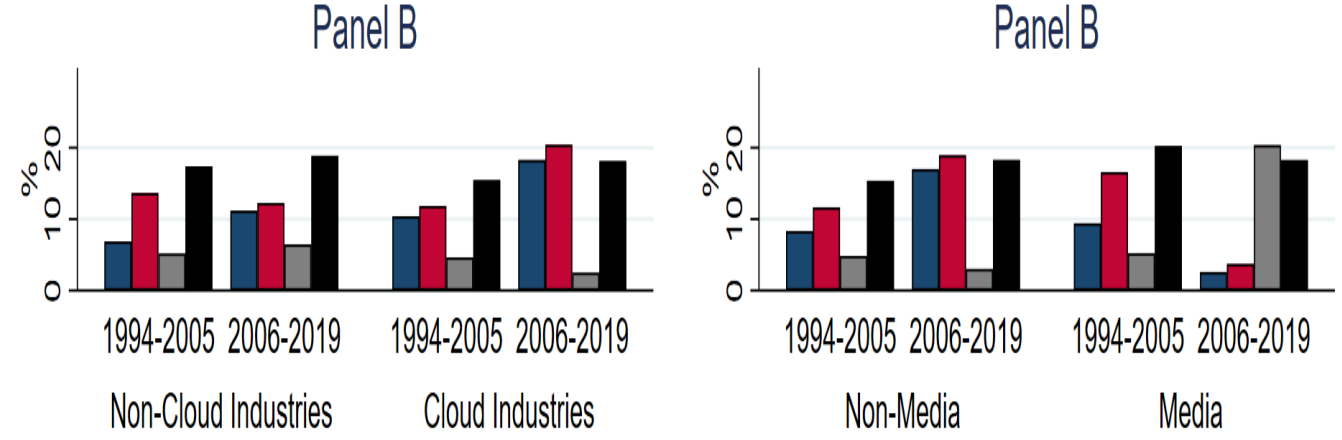

Figure 7. The Size of Different Types of Wedges in Dual-Class IPOs. This figure shows the wedge between voting rights and economic rights in percentages for different types of wedges: (1) Founder: the wedge of the founder, (2) Directors \& Officers: the wedge of the directors and officers, (3) Company: the wedge of a parent or holding company, and (4) Public: the wedge held by the public shareholders multiplied by $(-1)$ because typically this wedge is negative (that is, the voting rights are smaller than the economic rights). 


\section{Panel A: Trends in Cloud Industries}
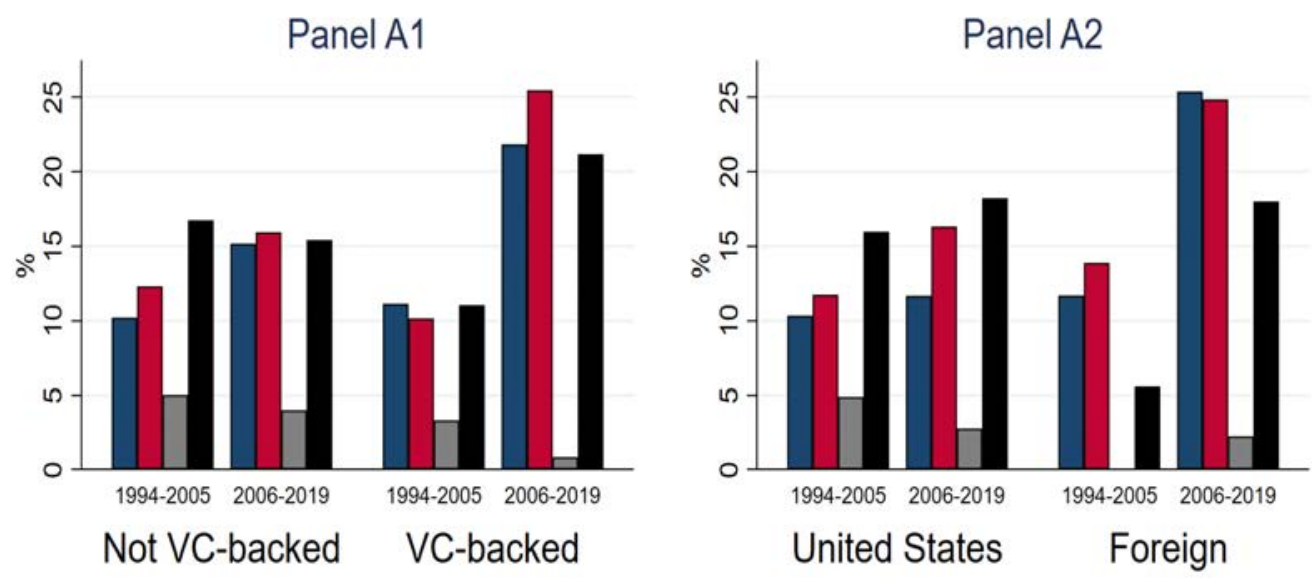

Panel B: Trends in Non-Cloud Industries
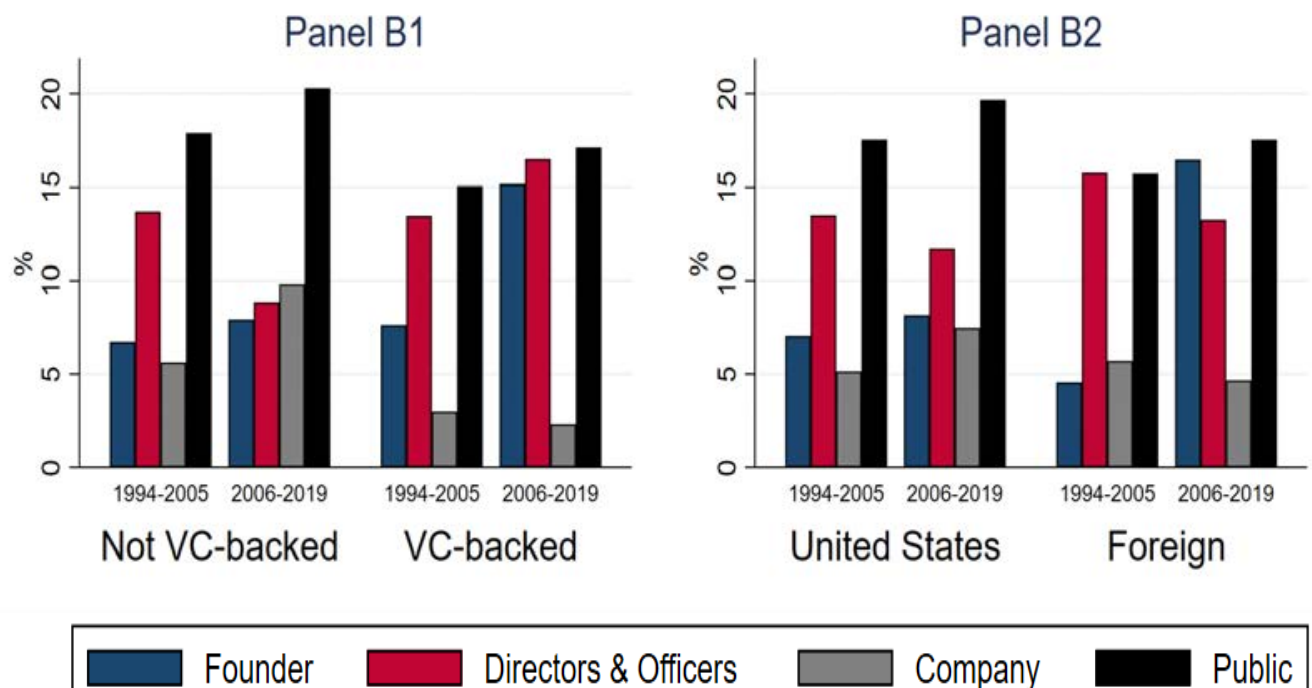

Directors \& Officers

Company

Public

Figure 8. Trends in Different Types of Wedges by Industry. This figure compares the average wedges between voting rights and economic rights in percentages for different types of wedges in 1994-2005 to those in 2006-2019. Different types of wedges include: (1) Founder: the wedge of the founder, (2) Directors \& Officers: the wedge of the directors and officers, (3) Company: the wedge of a parent or holding company, and (4) Public: the wedge held by the public shareholders multiplied by (-1) because typically this wedge is negative (that is, the voting rights are smaller than the economic rights). 
Panel A: Time Sunsets

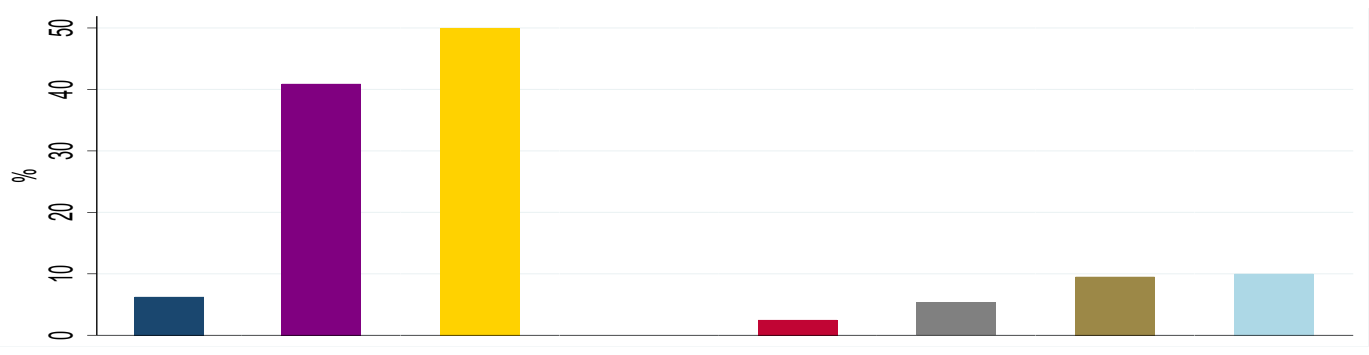

Panel B: Ownership Sunsets

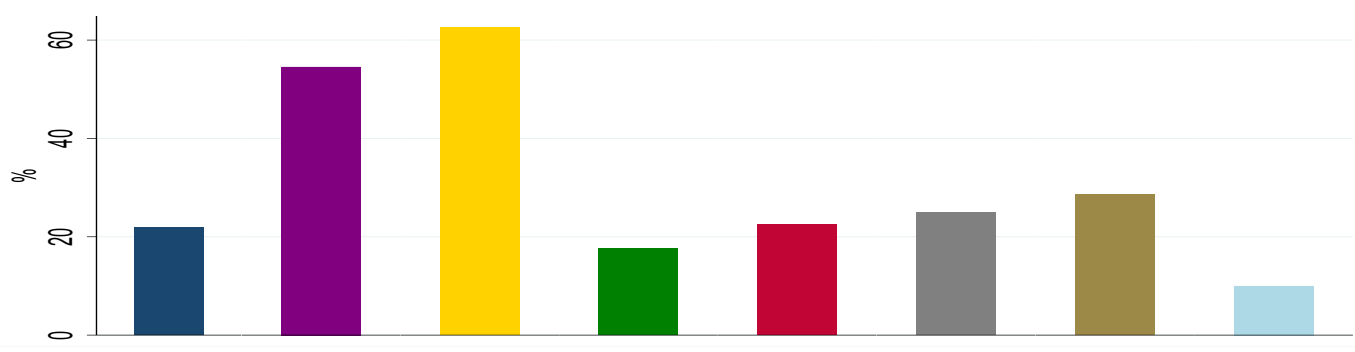

Panel C: Transfer Sunsets

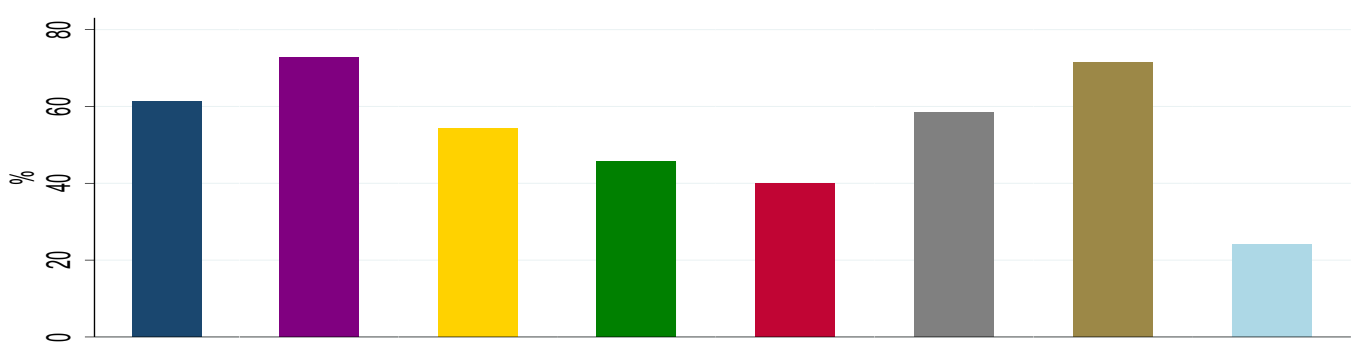

Panel D: Other Sunsets

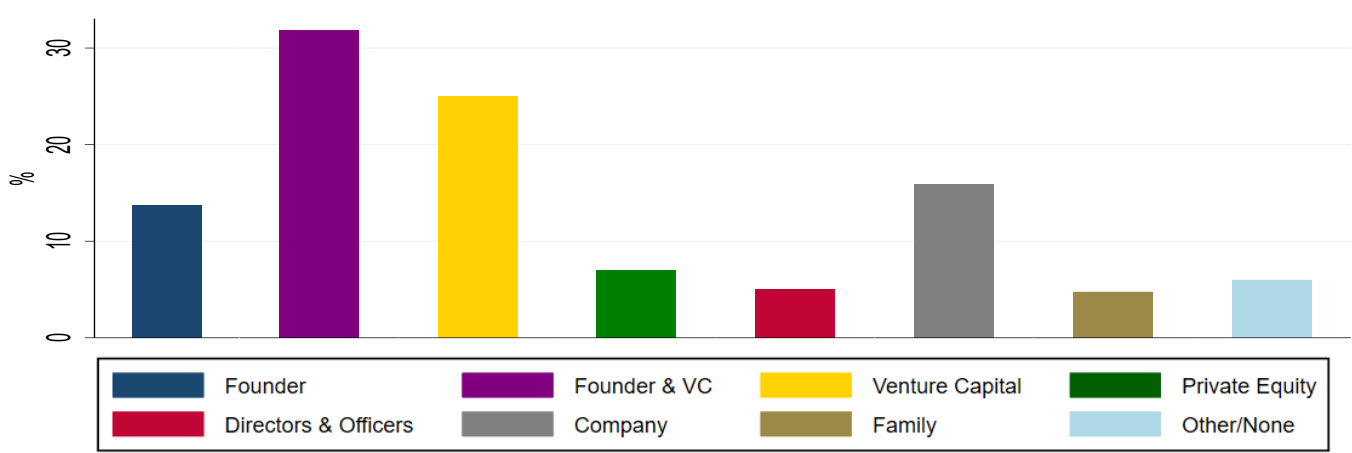

Figure 9. The Percentage of Different Types of Sunsets by Controller. This figure shows the percentage of dual-class IPOs that have different types of sunsets by the type of controller. Types of sunset provisions include: Time Sunsets (Panel A), Ownership Sunsets (Panel B), Transfer Sunsets (Panel C) and Other Sunsets (Panel D). Types of controllers include: Founder, Founder and Venture Capital Firm, Venture Capital Firm, Private Equity Firm, Directors \& Officers who are not founders, a Company which is a parent or holding company, a Family business, or other types of investors or no controller. 
Panel A: Time Sunsets

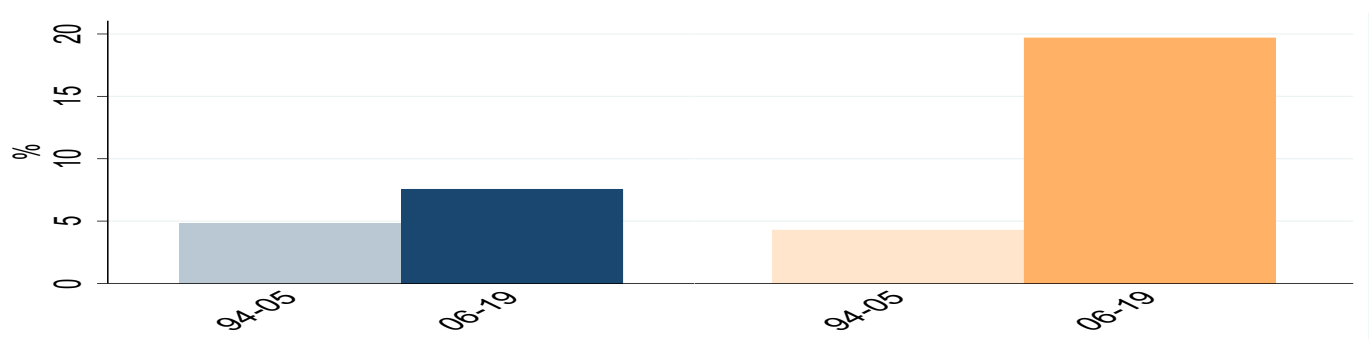

Panel B: Ownership Sunsets

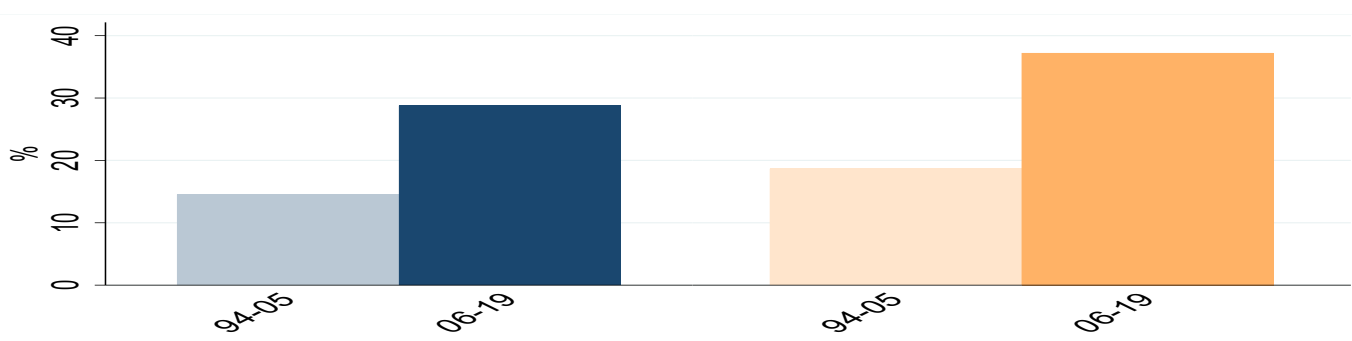

Panel C: Transfer Sunsets

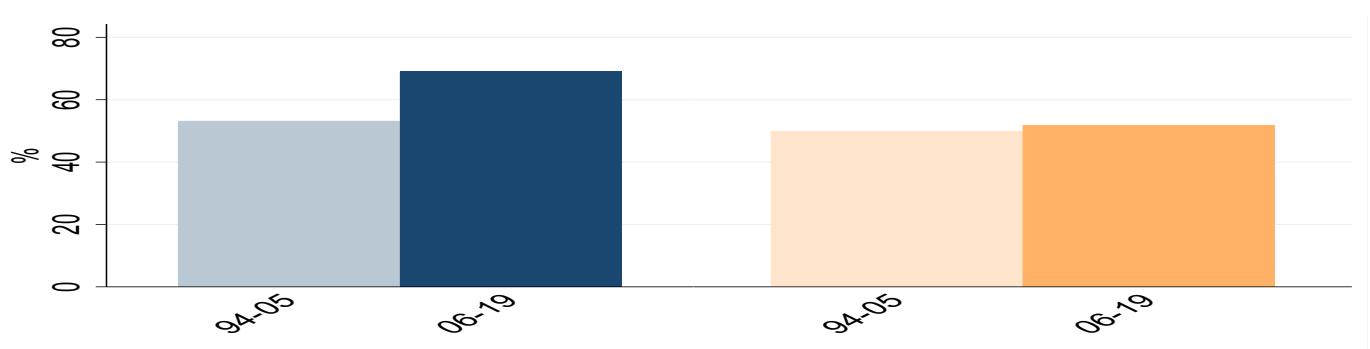

Panel D: Other Sunsets

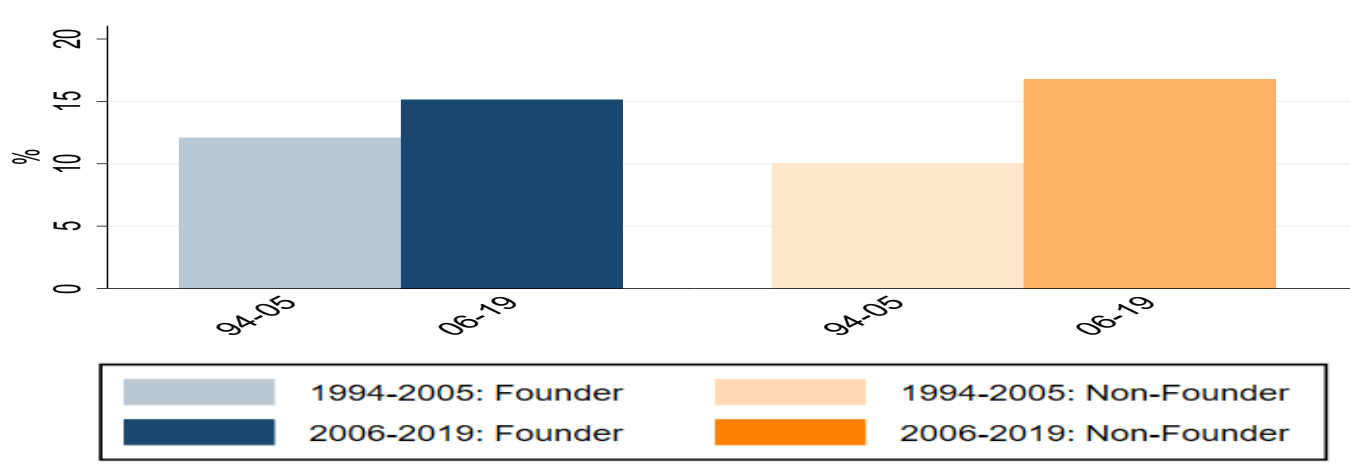

Figure 10. The Percentage of Different Types of Sunsets over Time by Founder Control. This figure shows the percentage of dual-class IPOs that have different types of sunsets, comparing IPOs in 1994-2005 to IPOs in 2006-2019. Each Panel divides dual-class IPOs into IPOs that are controlled solely by the founders and other dual-class IPOs. Types of sunset provisions include: Time Sunsets (Panel A), Ownership Sunsets (Panel B), Transfer Sunsets (Panel C) and Other Sunsets (Panel D). 
Table I

SUmmary Statistics of IPOs 1994-2019

\begin{tabular}{|c|c|c|c|c|c|c|c|c|c|c|c|c|c|c|}
\hline \multirow{3}{*}{ Variable } & \multicolumn{4}{|c|}{ Single Class IPOs } & \multicolumn{5}{|c|}{ Founder-Controlled Dual-Class IPOs } & \multicolumn{5}{|c|}{ Other Dual-Class IPOs } \\
\hline & $\begin{array}{c}\text { Obs } \\
(1)\end{array}$ & $\begin{array}{c}\text { Mean } \\
(2)\end{array}$ & $\begin{array}{l}\text { SD } \\
(3)\end{array}$ & $\begin{array}{c}\text { Med. } \\
(4)\end{array}$ & $\begin{array}{l}\text { Obs } \\
(5)\end{array}$ & $\begin{array}{c}\text { Mean } \\
(6)\end{array}$ & $\begin{array}{l}\text { SD } \\
(7)\end{array}$ & $\begin{array}{c}\text { Med. } \\
(8)\end{array}$ & $\begin{array}{c}\text { t-stat } \\
(6)-(2)\end{array}$ & $\begin{array}{l}\text { Obs } \\
(10)\end{array}$ & $\begin{array}{c}\text { Mean } \\
(11)\end{array}$ & $\begin{array}{l}\text { SD } \\
(12)\end{array}$ & $\begin{array}{r}\text { Med. } \\
(13)\end{array}$ & $\begin{array}{c}\text { t-stat } \\
(11)-(2)\end{array}$ \\
\hline & \multicolumn{14}{|c|}{ Panel A: Firm Characteristics } \\
\hline Age & 5,084 & 14.87 & 20.89 & 8 & 277 & 11.36 & 10.99 & 8 & -2.772 & 324 & 28.98 & 35.24 & 12 & 11.19 \\
\hline IPO Proceeds & 5,087 & 123.33 & 509.03 & 53.5 & 278 & 308.54 & 1172.03 & 100.35 & 5.344 & 324 & 385.19 & 1228.71 & 131.95 & 7.910 \\
\hline Eponymous & 5,078 & .08 & .27 & 0 & 274 & .12 & .32 & 0 & 2.003 & 323 & .14 & .34 & 0 & 3.362 \\
\hline Assets (\$ mil) & 4,868 & 459.96 & 1734.13 & 37.65 & 262 & 423.75 & 1285.49 & 126.45 & -0.333 & 300 & 1870.43 & 3706.13 & 330.67 & 12.45 \\
\hline $\mathrm{ROA}$ & 4,764 & -.23 & .75 & .03 & 258 & -.05 & .48 & .06 & 3.877 & 297 & -.07 & .55 & .04 & 3.707 \\
\hline Leverage & 4,853 & .24 & .34 & .08 & 262 & .2 & .31 & .04 & -1.671 & 299 & .26 & .3 & .13 & 1.086 \\
\hline Cash & 4,864 & .27 & .29 & .14 & 262 & .29 & .26 & .22 & 1.220 & 300 & .16 & .21 & .06 & -6.412 \\
\hline Patents (\#) & 5,089 & 5.16 & 67.63 & 0 & 278 & 5.62 & 36.89 & 0 & 0.111 & 324 & 8.76 & 69.36 & 0 & 0.927 \\
\hline Patents $(\$$ mil $)$ & 5,089 & 45.45 & 812.63 & 0 & 278 & 193.29 & 2482.17 & 0 & 2.470 & 324 & 69.44 & 424.63 & 0 & 0.527 \\
\hline $\mathrm{R} \& \mathrm{D}$ & 5,089 & .19 & .43 & 0 & 278 & .08 & .2 & 0 & -4.350 & 324 & .06 & .19 & 0 & -5.375 \\
\hline Missing RD & 5,089 & .41 & .49 & 0 & 278 & .47 & .5 & 0 & 2.174 & 324 & .6 & .49 & 1 & 6.850 \\
\hline Tobin's Q & 4,610 & 3.42 & 2.84 & 2.49 & 272 & 3.84 & 3.07 & 2.71 & 2.238 & 292 & 3.11 & 2.77 & 2.01 & -1.786 \\
\hline Price-to-Book Ratio & 4,610 & 4.78 & 4.67 & 3.28 & 272 & 5.85 & 5.42 & 3.89 & 3.440 & 292 & 5.04 & 5.19 & 3.23 & 0.915 \\
\hline & \multicolumn{14}{|c|}{ Panel B: IPO Type } \\
\hline VC-backed & 5,089 & .42 & .49 & 0 & 278 & .42 & .49 & 0 & 0.0955 & 324 & .23 & .42 & 0 & -6.874 \\
\hline Foreign-based & 5,089 & .1 & .3 & 0 & 278 & .35 & .48 & 0 & 12.93 & 324 & .14 & .35 & 0 & 2.096 \\
\hline Cloud Industry & 5,089 & .48 & .5 & 0 & 278 & .69 & .46 & 1 & 6.954 & 324 & .54 & .5 & 1 & 2.172 \\
\hline Media company & 5,089 & .06 & .24 & 0 & 265 & 3.82 & 3.04 & 2.71 & 3.555 & 324 & .15 & .36 & 0 & 5.804 \\
\hline Spin-offs & 5,089 & .16 & .36 & 0 & 265 & 5.8 & 5.37 & 3.85 & -5.038 & 324 & .36 & .48 & 0 & 9.511 \\
\hline & \multicolumn{14}{|c|}{ Panel C: The Size of the Wedge } \\
\hline Public Wedge & - & - & - & - & 278 & -22.68 & 17.22 & -22.02 & - & 324 & -12.66 & 17.25 & -10.72 & - \\
\hline Founder Wedge & - & - & - & - & 278 & 25.49 & 19.3 & 23.33 & - & 324 & .82 & 5.92 & 0 & - \\
\hline D\&O Wedge & - & - & - & - & 278 & 25.89 & 18.2 & 24.5 & - & 324 & 6.42 & 13.57 & 0 & - \\
\hline Non-Founder D\&O Wedge & - & - & - & - & 278 & .9 & 10.95 & -.05 & - & 324 & 5.86 & 12.97 & 0 & - \\
\hline Company Wedge & - & - & - & - & 278 & 0 & 0 & 0 & - & 324 & 7.85 & 13.04 & 0 & - \\
\hline & \multicolumn{14}{|c|}{ Panel D: Sunsets } \\
\hline Time Sunsets & - & - & - & - & 278 & .09 & .29 & 0 & - & 324 & .08 & .28 & 0 & - \\
\hline Ownership Sunsets & - & - & - & - & 278 & .25 & .43 & 0 & - & 324 & .24 & .43 & 0 & - \\
\hline Transfer Sunsets & - & - & - & - & 278 & .62 & .49 & 1 & - & 324 & .49 & .5 & 0 & - \\
\hline Other Sunsets & - & - & - & - & 278 & .15 & .36 & 0 & - & 324 & .11 & .31 & 0 & - \\
\hline & \multicolumn{14}{|c|}{ Panel E: Venture Capital Financing } \\
\hline VC Ind. Financing & 5,089 & 2.72 & 5.28 & .63 & 278 & 6.19 & 8.78 & .96 & 10.21 & 324 & 3.19 & 6.43 & .34 & 1.530 \\
\hline Dry Powder & 5,089 & 18.15 & 29.84 & 4.07 & 278 & 31.94 & 40.96 & 3.12 & 7.338 & 324 & 17.32 & 31.13 & 1.36 & -0.483 \\
\hline
\end{tabular}


Table II

The Determinants of Controllers in Dual-Class IPOs

\begin{tabular}{|c|c|c|c|c|c|c|c|c|c|c|}
\hline & \multicolumn{5}{|c|}{ Ind. Capital = VC Industry Financing } & \multicolumn{5}{|c|}{ Ind. Capital = Ind. Dry Powder } \\
\hline & $\begin{array}{c}\text { Dual-Class } \\
\text { (1) }\end{array}$ & $\begin{array}{c}\text { Founder } \\
(2)\end{array}$ & $\begin{array}{c}\text { NF Dual } \\
(3)\end{array}$ & $\begin{array}{c}\text { NF D\&O } \\
(4)\end{array}$ & $\begin{array}{l}\text { Co. } \\
(5)\end{array}$ & $\begin{array}{c}\text { Dual-Class } \\
(6)\end{array}$ & $\begin{array}{c}\text { Founder } \\
(7)\end{array}$ & $\begin{array}{c}\text { NF Dual } \\
(8)\end{array}$ & $\begin{array}{c}\text { NF D\&O } \\
(9)\end{array}$ & $\begin{array}{l}\text { Co. } \\
(10)\end{array}$ \\
\hline Ind. Capital & $\begin{array}{c}0.00709^{* * *} \\
(5.44)\end{array}$ & $\begin{array}{c}0.00557^{* * *} \\
(5.24)\end{array}$ & $\begin{array}{c}0.00153 \\
(1.58)\end{array}$ & $\begin{array}{c}0.000204 \\
(0.86)\end{array}$ & $\begin{array}{c}0.000229 \\
(0.38)\end{array}$ & $\begin{array}{c}0.00119^{* * *} \\
(5.20)\end{array}$ & $\begin{array}{c}0.000965^{* * *} \\
(5.82)\end{array}$ & $\begin{array}{c}0.000227 \\
(1.31)\end{array}$ & $\begin{array}{c}0.0000766 \\
(1.47)\end{array}$ & $\begin{array}{c}0.000144 \\
(1.20)\end{array}$ \\
\hline VC-backed & $\begin{array}{c}-0.0101 \\
(-1.00)\end{array}$ & $\begin{array}{c}0.00355 \\
(0.50)\end{array}$ & $\begin{array}{c}-0.0136^{*} \\
(-1.72)\end{array}$ & $\begin{array}{c}-0.00318 \\
(-1.22)\end{array}$ & $\begin{array}{c}-0.0216^{* * *} \\
(-4.50)\end{array}$ & $\begin{array}{c}-0.0104 \\
(-1.03)\end{array}$ & $\begin{array}{c}0.00327 \\
(0.46)\end{array}$ & $\begin{array}{c}-0.0136^{*} \\
(-1.72)\end{array}$ & $\begin{array}{c}-0.00325 \\
(-1.25)\end{array}$ & $\begin{array}{c}-0.0217^{* * *} \\
(-4.52)\end{array}$ \\
\hline Cloud Ind. & $\begin{array}{c}0.180^{* * *} \\
(2.97)\end{array}$ & $\begin{array}{c}0.0966^{* * *} \\
(2.59)\end{array}$ & $\begin{array}{c}0.0833^{* *} \\
(2.12)\end{array}$ & $\begin{array}{c}0.00561 \\
(0.75)\end{array}$ & $\begin{array}{c}0.0555^{*} \\
(1.81)\end{array}$ & $\begin{array}{c}0.187^{* * *} \\
(2.95)\end{array}$ & $\begin{array}{c}0.102^{* * *} \\
(2.63)\end{array}$ & $\begin{array}{c}0.0846^{* *} \\
(2.12)\end{array}$ & $\begin{array}{c}0.00604 \\
(0.80)\end{array}$ & $\begin{array}{c}0.0563^{*} \\
(1.85)\end{array}$ \\
\hline Foreign & $\begin{array}{c}0.0841^{\text {*** }} \\
\quad(5.32)\end{array}$ & $\begin{array}{c}0.0826^{* * *} \\
\quad(6.38)\end{array}$ & $\begin{array}{c}0.00153 \\
(0.14)\end{array}$ & $\begin{array}{c}0.00110 \\
(0.30)\end{array}$ & $\begin{array}{c}0.00289 \\
(0.39)\end{array}$ & $\begin{array}{c}0.0842^{* * *} \\
\quad(5.33)\end{array}$ & $\begin{array}{c}0.0826^{* * *} \\
(6.39)\end{array}$ & $\begin{array}{c}0.00163 \\
(0.15)\end{array}$ & $\begin{array}{c}0.001000 \\
(0.27)\end{array}$ & $\begin{array}{c}0.00264 \\
(0.36)\end{array}$ \\
\hline Media & $\begin{array}{c}0.0501^{*} \\
(1.79)\end{array}$ & $\begin{array}{c}0.0130 \\
(0.88)\end{array}$ & $\begin{array}{c}0.0372 \\
(1.51)\end{array}$ & $\begin{array}{c}0.00826 \\
(0.95)\end{array}$ & $\begin{array}{c}0.0196 \\
(1.05)\end{array}$ & $\begin{array}{c}0.0499^{*} \\
(1.78)\end{array}$ & $\begin{array}{c}0.0128 \\
(0.87)\end{array}$ & $\begin{array}{c}0.0372 \\
(1.51)\end{array}$ & $\begin{array}{c}0.00822 \\
(0.94)\end{array}$ & $\begin{array}{c}0.0195 \\
(1.05)\end{array}$ \\
\hline Eponymous & $\begin{array}{c}0.0275 \\
(1.61)\end{array}$ & $\begin{array}{c}0.0296^{* *} \\
(2.49)\end{array}$ & $\begin{array}{c}-0.00206 \\
(-0.15)\end{array}$ & $\begin{array}{c}-0.00250 \\
(-0.49)\end{array}$ & $\begin{array}{c}0.00162 \\
(0.18)\end{array}$ & $\begin{array}{c}0.0268 \\
(1.57)\end{array}$ & $\begin{array}{c}0.0290^{* *} \\
(2.44)\end{array}$ & $\begin{array}{c}-0.00221 \\
(-0.16)\end{array}$ & $\begin{array}{c}-0.00254 \\
(-0.50)\end{array}$ & $\begin{array}{c}0.00156 \\
(0.18)\end{array}$ \\
\hline $\log ($ Age $)$ & $\begin{array}{c}-0.00677 \\
(-1.24)\end{array}$ & $\begin{array}{c}-0.00989^{* * *} \\
(-3.04)\end{array}$ & $\begin{array}{c}0.00312 \\
(0.67)\end{array}$ & $\begin{array}{c}0.00118 \\
(0.66)\end{array}$ & $\begin{array}{c}-0.00154 \\
(-0.55)\end{array}$ & $\begin{array}{c}-0.00685 \\
(-1.25)\end{array}$ & $\begin{array}{c}-0.00992^{* * *} \\
(-3.05)\end{array}$ & $\begin{array}{c}0.00307 \\
(0.66)\end{array}$ & $\begin{array}{c}0.00121 \\
(0.68)\end{array}$ & $\begin{array}{c}-0.00144 \\
(-0.51)\end{array}$ \\
\hline Log(Assets) & $\begin{array}{c}0.0390^{* * *} \\
(10.92)\end{array}$ & $\begin{array}{c}0.00868^{* * *} \\
(3.90)\end{array}$ & $\begin{array}{c}0.0303^{* * *} \\
(10.03)\end{array}$ & $\begin{array}{c}0.00165 \\
(1.47)\end{array}$ & $\begin{array}{c}0.0139^{* * *} \\
(6.33)\end{array}$ & $\begin{array}{c}0.0393^{* * *} \\
(11.02)\end{array}$ & $\begin{array}{c}0.00890^{* * *} \\
(3.98)\end{array}$ & $\begin{array}{c}0.0304^{* * *} \\
(10.07)\end{array}$ & $\begin{array}{c}0.00162 \\
(1.45)\end{array}$ & $\begin{array}{c}0.0139^{* * *} \\
\quad(6.34)\end{array}$ \\
\hline Patents (\$ Mil) & $\begin{array}{c}0.00567 \\
(1.63)\end{array}$ & $\begin{array}{c}0.00593^{* *} \\
(2.45)\end{array}$ & $\begin{array}{c}-0.000255 \\
(-0.09)\end{array}$ & $\begin{array}{c}0.00113 \\
(0.99)\end{array}$ & $\begin{array}{c}-0.00180 \\
(-0.97)\end{array}$ & $\begin{array}{c}0.00556 \\
(1.60)\end{array}$ & $\begin{array}{c}0.00584^{* *} \\
(2.43)\end{array}$ & $\begin{array}{c}-0.000284 \\
(-0.10)\end{array}$ & $\begin{array}{c}0.00113 \\
(0.99)\end{array}$ & $\begin{array}{c}-0.00178 \\
(-0.96)\end{array}$ \\
\hline $\mathrm{ROA}$ & $\begin{array}{c}-0.0198^{* * *} \\
(-3.36)\end{array}$ & $\begin{array}{c}0.00448 \\
(1.16)\end{array}$ & $\begin{array}{c}-0.0243^{* * *} \\
(-5.29)\end{array}$ & $\begin{array}{c}-0.00365^{*} \\
(-1.88)\end{array}$ & $\begin{array}{c}-0.0118^{* * *} \\
(-3.37)\end{array}$ & $\begin{array}{c}-0.0208^{* * *} \\
(-3.54)\end{array}$ & $\begin{array}{c}0.00367 \\
(0.95)\end{array}$ & $\begin{array}{c}-0.0245^{* * *} \\
(-5.34)\end{array}$ & $\begin{array}{c}-0.00367^{*} \\
(-1.90)\end{array}$ & $\begin{array}{c}-0.0118^{* * *} \\
(-3.37)\end{array}$ \\
\hline Leverage & $\begin{array}{c}-0.0390^{* * *} \\
(-3.24)\end{array}$ & $\begin{array}{c}-0.00486 \\
(-0.58)\end{array}$ & $\begin{array}{c}-0.0342^{* * *} \\
(-3.67)\end{array}$ & $\begin{array}{c}0.000630 \\
(0.16)\end{array}$ & $\begin{array}{c}-0.0396^{* * *} \\
(-6.40)\end{array}$ & $\begin{array}{c}-0.0401^{* * *} \\
(-3.33)\end{array}$ & $\begin{array}{c}-0.00571 \\
(-0.68)\end{array}$ & $\begin{array}{c}-0.0344^{* * *} \\
(-3.70)\end{array}$ & $\begin{array}{c}0.000613 \\
(0.16)\end{array}$ & $\begin{array}{c}-0.0396^{\text {*** }} \\
(-6.40)\end{array}$ \\
\hline Cash & $\begin{array}{c}0.00774 \\
(0.41)\end{array}$ & $\begin{array}{c}0.0180 \\
(1.36)\end{array}$ & $\begin{array}{c}-0.0102 \\
(-0.70)\end{array}$ & $\begin{array}{c}0.00160 \\
(0.32)\end{array}$ & $\begin{array}{c}-0.0144 \\
(-1.31)\end{array}$ & $\begin{array}{c}0.00714 \\
(0.38)\end{array}$ & $\begin{array}{c}0.0174 \\
(1.32)\end{array}$ & $\begin{array}{c}-0.0103 \\
(-0.70)\end{array}$ & $\begin{array}{c}0.00149 \\
(0.30)\end{array}$ & $\begin{array}{c}-0.0146 \\
(-1.33)\end{array}$ \\
\hline Positive R\&D & $\begin{array}{c}-0.0198 \\
(-0.89)\end{array}$ & $\begin{array}{c}-0.0314^{*} \\
(-1.96)\end{array}$ & $\begin{array}{c}0.0116 \\
(0.72)\end{array}$ & $\begin{array}{c}0.00501 \\
(0.73)\end{array}$ & $\begin{array}{c}0.00730 \\
(0.67)\end{array}$ & $\begin{array}{c}-0.0211 \\
(-0.96)\end{array}$ & $\begin{array}{c}-0.0324^{* *} \\
(-2.03)\end{array}$ & $\begin{array}{c}0.0113 \\
(0.70)\end{array}$ & $\begin{array}{c}0.00496 \\
(0.72)\end{array}$ & $\begin{array}{c}0.00723 \\
(0.66)\end{array}$ \\
\hline Missing R\&D & $\begin{array}{c}0.00191 \\
(0.09)\end{array}$ & $\begin{array}{c}-0.0206 \\
(-1.34)\end{array}$ & $\begin{array}{c}0.0225 \\
(1.50)\end{array}$ & $\begin{array}{c}0.00650 \\
(0.89)\end{array}$ & $\begin{array}{c}-0.00151 \\
(-0.17)\end{array}$ & $\begin{array}{c}0.000147 \\
(0.01)\end{array}$ & $\begin{array}{c}-0.0220 \\
(-1.43)\end{array}$ & $\begin{array}{c}0.0222 \\
(1.48)\end{array}$ & $\begin{array}{c}0.00646 \\
(0.88)\end{array}$ & $\begin{array}{c}-0.00154 \\
(-0.17)\end{array}$ \\
\hline Spinoff & $\begin{array}{c}-0.00648 \\
(-0.52)\end{array}$ & $\begin{array}{c}-0.0534^{* * *} \\
(-8.25)\end{array}$ & $\begin{array}{c}0.0469^{* * *} \\
(4.08)\end{array}$ & $\begin{array}{c}-0.00228 \\
(-0.63)\end{array}$ & $\begin{array}{c}0.0436^{* * *} \\
(4.99)\end{array}$ & $\begin{array}{c}-0.00757 \\
(-0.61)\end{array}$ & $\begin{array}{c}-0.0542^{* * *} \\
(-8.37)\end{array}$ & $\begin{array}{c}0.0466^{* * *} \\
(4.06)\end{array}$ & $\begin{array}{c}-0.00226 \\
(-0.63)\end{array}$ & $\begin{array}{c}0.0437^{* * *} \\
(4.99)\end{array}$ \\
\hline $\begin{array}{l}\text { Adj. } R^{2} \\
\mathrm{~N}\end{array}$ & $\begin{array}{l}0.130 \\
5,294 \\
\end{array}$ & $\begin{array}{l}0.110 \\
5,294 \\
\end{array}$ & $\begin{array}{c}0.0859 \\
5,294 \\
\end{array}$ & $\begin{array}{c}0.0272 \\
5,294 \\
\end{array}$ & $\begin{array}{c}0.0608 \\
5,294 \\
\end{array}$ & $\begin{array}{l}0.128 \\
5,294 \\
\end{array}$ & $\begin{array}{l}0.108 \\
5,294 \\
\end{array}$ & $\begin{array}{c}0.0856 \\
5,294 \\
\end{array}$ & $\begin{array}{c}0.0274 \\
5,294 \\
\end{array}$ & $\begin{array}{c}0.0610 \\
5,294 \\
\end{array}$ \\
\hline
\end{tabular}

This table presents the results of a linear probability model where the dependent variable is an indicator that equals 1 if an IPO has: dual-class stock in columns (1) and (6), a founder-controlled dual-class structure in columns (2) and (7), a dual-class structure not controlled by a founder in columns (3) and (8), a dual-class structure controlled by non-founder directors and officers in columns (4) and (9), and a dual-class structure controlled by a parent or holding company in columns (5) and (10). All specifications include year and two-digit SIC industry fixed effects. All variables are described in the Appendix. All standard errors are robust. ***, **, and * denote significance at the $1 \%, 5 \%$, and $10 \%$ levels. Columns (1) through (5) use VC Industry Financing as a proxy for VC investments, while columns (6) through (10) use Industry Dry Powder. 
Table III

The Determinants of the Wedge between Voting Rights and Economic Rights

\begin{tabular}{|c|c|c|c|c|c|c|c|c|c|c|}
\hline & \multicolumn{5}{|c|}{ Ind. Capital = VC Industry Financing } & \multicolumn{5}{|c|}{ Ind. Capital = Ind. Dry Powder } \\
\hline & $\begin{array}{c}\text { Public } \\
(1)\end{array}$ & $\begin{array}{c}\text { Founder } \\
(2)\end{array}$ & $\begin{array}{c}\mathrm{D} \& \mathrm{O} \\
(3)\end{array}$ & $\begin{array}{c}\text { NF D\&O } \\
(4)\end{array}$ & $\begin{array}{l}\text { Co. } \\
(5)\end{array}$ & $\begin{array}{c}\text { Public } \\
(6)\end{array}$ & $\begin{array}{c}\text { Founder } \\
(7)\end{array}$ & $\begin{array}{c}\mathrm{D} \& \mathrm{O} \\
(8)\end{array}$ & $\begin{array}{c}\text { NF D\&O } \\
(9)\end{array}$ & $\begin{array}{l}\text { Co. } \\
(10)\end{array}$ \\
\hline Ind. Capital & $\begin{array}{c}-0.199^{* * *} \\
(-5.38)\end{array}$ & $\begin{array}{c}0.197^{* * *} \\
(4.92)\end{array}$ & $\begin{array}{c}0.244^{* * *} \\
(5.80)\end{array}$ & $\begin{array}{c}0.0504^{* * *} \\
(2.78)\end{array}$ & $\begin{array}{c}-0.00258 \\
(-0.19)\end{array}$ & $\begin{array}{c}-0.0328^{* * *} \\
(-5.19)\end{array}$ & $\begin{array}{c}0.0265^{* * *} \\
(4.72)\end{array}$ & $\begin{array}{c}0.0350^{* * *} \\
(5.72)\end{array}$ & $\begin{array}{c}0.0105^{* * *} \\
(3.23)\end{array}$ & $\begin{array}{c}0.00101 \\
(0.34)\end{array}$ \\
\hline VC-backed & $\begin{array}{l}0.264 \\
(1.01)\end{array}$ & $\begin{array}{c}0.0498 \\
(0.22)\end{array}$ & $\begin{array}{l}0.0941 \\
(0.37)\end{array}$ & $\begin{array}{c}0.0586 \\
(0.38)\end{array}$ & $\begin{array}{c}-0.403^{* * *} \\
(-3.25)\end{array}$ & $\begin{array}{l}0.272 \\
(1.04)\end{array}$ & $\begin{array}{c}0.0501 \\
(0.22)\end{array}$ & $\begin{array}{c}0.0915 \\
(0.36)\end{array}$ & $\begin{array}{c}0.0537 \\
(0.35)\end{array}$ & $\begin{array}{c}-0.405^{* * *} \\
(-3.25)\end{array}$ \\
\hline Cloud Ind. & $\begin{array}{c}-3.836^{* *} \\
(-2.40)\end{array}$ & $\begin{array}{c}3.204^{* *} \\
(2.15)\end{array}$ & $\begin{array}{c}3.620^{* *} \\
(2.14)\end{array}$ & $\begin{array}{l}0.432 \\
(0.90)\end{array}$ & $\begin{array}{l}1.019^{*} \\
(1.75)\end{array}$ & $\begin{array}{c}-4.025^{* *} \\
(-2.41)\end{array}$ & $\begin{array}{c}3.359^{* *} \\
(2.14)\end{array}$ & $\begin{array}{c}3.823^{* *} \\
(2.13)\end{array}$ & $\begin{array}{l}0.492 \\
(1.01)\end{array}$ & $\begin{array}{l}1.024^{*} \\
(1.77)\end{array}$ \\
\hline Foreign & $\begin{array}{c}-1.090^{* * *} \\
(-2.77)\end{array}$ & $\begin{array}{c}2.726^{* * *} \\
(6.03)\end{array}$ & $\begin{array}{c}2.455^{* * *} \\
(5.17)\end{array}$ & $\begin{array}{l}-0.250 \\
(-0.98)\end{array}$ & $\begin{array}{c}-0.0274 \\
(-0.16)\end{array}$ & $\begin{array}{c}-1.095^{* * *} \\
(-2.78)\end{array}$ & $\begin{array}{c}2.745^{* * *} \\
(6.01)\end{array}$ & $\begin{array}{c}2.474^{* * *} \\
(5.17)\end{array}$ & $\begin{array}{l}-0.255 \\
(-1.00)\end{array}$ & $\begin{array}{c}-0.0310 \\
(-0.18)\end{array}$ \\
\hline Media & $\begin{array}{l}-0.888 \\
(-1.39)\end{array}$ & $\begin{array}{c}-0.00933 \\
(-0.02)\end{array}$ & $\begin{array}{l}0.518 \\
(0.86)\end{array}$ & $\begin{array}{l}0.521 \\
(1.05)\end{array}$ & $\begin{array}{c}0.0952 \\
(0.28)\end{array}$ & $\begin{array}{l}-0.882 \\
(-1.38)\end{array}$ & $\begin{array}{c}-0.00981 \\
(-0.03)\end{array}$ & $\begin{array}{l}0.516 \\
(0.86)\end{array}$ & $\begin{array}{l}0.518 \\
(1.04)\end{array}$ & $\begin{array}{c}0.0941 \\
(0.27)\end{array}$ \\
\hline Eponymous & $\begin{array}{c}-1.076^{* *} \\
(-2.12)\end{array}$ & $\begin{array}{c}0.756^{*} \\
(1.81)\end{array}$ & $\begin{array}{c}1.145^{* *} \\
(2.41)\end{array}$ & $\begin{array}{l}0.324 \\
(1.40)\end{array}$ & $\begin{array}{c}-0.0411 \\
(-0.24)\end{array}$ & $\begin{array}{c}-1.056^{* *} \\
(-2.08)\end{array}$ & $\begin{array}{c}0.738^{*} \\
(1.76)\end{array}$ & $\begin{array}{c}1.122^{* *} \\
(2.36)\end{array}$ & $\begin{array}{l}0.318 \\
(1.37)\end{array}$ & $\begin{array}{c}-0.0414 \\
(-0.25)\end{array}$ \\
\hline Log(Age) & $\begin{array}{l}0.286^{*} \\
(1.87)\end{array}$ & $\begin{array}{c}-0.398^{* * *} \\
(-3.32)\end{array}$ & $\begin{array}{c}-0.242^{*} \\
(-1.71)\end{array}$ & $\begin{array}{l}0.164^{*} \\
(1.69)\end{array}$ & $\begin{array}{c}-0.116^{*} \\
(-1.82)\end{array}$ & $\begin{array}{l}0.289^{*} \\
(1.89)\end{array}$ & $\begin{array}{c}-0.407^{* * *} \\
(-3.37)\end{array}$ & $\begin{array}{c}-0.251^{*} \\
(-1.76)\end{array}$ & $\begin{array}{l}0.165^{*} \\
(1.70)\end{array}$ & $\begin{array}{c}-0.114^{*} \\
(-1.79)\end{array}$ \\
\hline Log(Assets) & $\begin{array}{c}-0.603^{* * *} \\
(-6.42)\end{array}$ & $\begin{array}{c}0.300^{* * *} \\
(3.53)\end{array}$ & $\begin{array}{c}0.366^{* * *} \\
(4.10)\end{array}$ & $\begin{array}{c}0.0786^{*} \\
(1.75)\end{array}$ & $\begin{array}{c}0.249^{* * *} \\
(5.76)\end{array}$ & $\begin{array}{c}-0.613^{* * *} \\
(-6.49)\end{array}$ & $\begin{array}{c}0.314^{* * *} \\
(3.66)\end{array}$ & $\begin{array}{c}0.381^{\text {*** }} \\
(4.24)\end{array}$ & $\begin{array}{c}0.0792^{*} \\
(1.76)\end{array}$ & $\begin{array}{c}0.247^{* * *} \\
(5.76)\end{array}$ \\
\hline Patents $(\$$ Mil $)$ & $\begin{array}{l}-0.117 \\
(-1.31)\end{array}$ & $\begin{array}{c}0.202^{* * *} \\
(3.04)\end{array}$ & $\begin{array}{c}0.212^{* *} \\
(2.54)\end{array}$ & $\begin{array}{c}0.00313 \\
(0.07)\end{array}$ & $\begin{array}{c}-0.0418 \\
(-1.09)\end{array}$ & $\begin{array}{l}-0.113 \\
(-1.28)\end{array}$ & $\begin{array}{c}0.198^{* * *} \\
(3.00)\end{array}$ & $\begin{array}{c}0.207^{* *} \\
(2.49)\end{array}$ & $\begin{array}{c}0.00270 \\
(0.06)\end{array}$ & $\begin{array}{c}-0.0415 \\
(-1.08)\end{array}$ \\
\hline $\mathrm{ROA}$ & $\begin{array}{l}0.133 \\
(0.99)\end{array}$ & $\begin{array}{c}0.0690 \\
(0.60)\end{array}$ & $\begin{array}{c}0.0536 \\
(0.39)\end{array}$ & $\begin{array}{c}-0.00646 \\
(-0.08)\end{array}$ & $\begin{array}{c}-0.251^{* * *} \\
(-2.93)\end{array}$ & $\begin{array}{l}0.162 \\
(1.21)\end{array}$ & $\begin{array}{c}0.0386 \\
(0.33)\end{array}$ & $\begin{array}{c}0.0164 \\
(0.12)\end{array}$ & $\begin{array}{c}-0.0134 \\
(-0.17)\end{array}$ & $\begin{array}{c}-0.250^{* * *} \\
(-2.92)\end{array}$ \\
\hline Leverage & $\begin{array}{l}0.354 \\
(1.03)\end{array}$ & $\begin{array}{l}0.212 \\
(0.70)\end{array}$ & $\begin{array}{l}0.106 \\
(0.33)\end{array}$ & $\begin{array}{c}0.000826 \\
(0.00)\end{array}$ & $\begin{array}{c}-0.825^{* * *} \\
(-5.69)\end{array}$ & $\begin{array}{l}0.384 \\
(1.12)\end{array}$ & $\begin{array}{l}0.179 \\
(0.59)\end{array}$ & $\begin{array}{c}0.0669 \\
(0.21)\end{array}$ & $\begin{array}{c}-0.00623 \\
(-0.04)\end{array}$ & $\begin{array}{c}-0.824^{* * *} \\
(-5.69)\end{array}$ \\
\hline Cash & $\begin{array}{c}0.0937 \\
(0.21)\end{array}$ & $\begin{array}{l}0.118 \\
(0.26)\end{array}$ & $\begin{array}{c}0.0109 \\
(0.02)\end{array}$ & $\begin{array}{l}-0.150 \\
(-0.53)\end{array}$ & $\begin{array}{c}-0.602^{* * *} \\
(-2.70)\end{array}$ & $\begin{array}{l}0.109 \\
(0.25)\end{array}$ & $\begin{array}{l}0.116 \\
(0.26)\end{array}$ & $\begin{array}{c}0.00373 \\
(0.01)\end{array}$ & $\begin{array}{l}-0.159 \\
(-0.57)\end{array}$ & $\begin{array}{c}-0.605^{* * *} \\
(-2.72)\end{array}$ \\
\hline Positive R\&D & $\begin{array}{l}0.223 \\
(0.37)\end{array}$ & $\begin{array}{l}-0.750 \\
(-1.35)\end{array}$ & $\begin{array}{l}-0.946 \\
(-1.54)\end{array}$ & $\begin{array}{l}-0.133 \\
(-0.43)\end{array}$ & $\begin{array}{c}0.0675 \\
(0.25)\end{array}$ & $\begin{array}{l}0.261 \\
(0.44)\end{array}$ & $\begin{array}{l}-0.785 \\
(-1.42)\end{array}$ & $\begin{array}{l}-0.991 \\
(-1.62)\end{array}$ & $\begin{array}{l}-0.143 \\
(-0.46)\end{array}$ & $\begin{array}{c}0.0676 \\
(0.25)\end{array}$ \\
\hline Missing R\&D & $\begin{array}{c}0.0393 \\
(0.07)\end{array}$ & $\begin{array}{l}-0.433 \\
(-0.82)\end{array}$ & $\begin{array}{l}-0.395 \\
(-0.68)\end{array}$ & $\begin{array}{c}0.0824 \\
(0.28)\end{array}$ & $\begin{array}{l}-0.168 \\
(-0.78)\end{array}$ & $\begin{array}{c}0.0888 \\
(0.16)\end{array}$ & $\begin{array}{l}-0.483 \\
(-0.92)\end{array}$ & $\begin{array}{l}-0.457 \\
(-0.79)\end{array}$ & $\begin{array}{c}0.0704 \\
(0.24)\end{array}$ & $\begin{array}{l}-0.167 \\
(-0.78)\end{array}$ \\
\hline Spinoff & $\begin{array}{c}0.771^{* * *} \\
(2.68)\end{array}$ & $\begin{array}{c}-1.621^{* * *} \\
(-8.42)\end{array}$ & $\begin{array}{c}-1.795^{* * *} \\
(-7.31)\end{array}$ & $\begin{array}{l}-0.237 \\
(-1.30)\end{array}$ & $\begin{array}{c}0.739^{* * *} \\
(3.96)\end{array}$ & $\begin{array}{c}0.802^{* * *} \\
(2.79)\end{array}$ & $\begin{array}{c}-1.659^{* * *} \\
(-8.57)\end{array}$ & $\begin{array}{c}-1.839^{* * *} \\
(-7.47)\end{array}$ & $\begin{array}{l}-0.242 \\
(-1.34)\end{array}$ & $\begin{array}{c}0.741^{* * *} \\
(3.96)\end{array}$ \\
\hline $\begin{array}{l}\text { Adj. } R^{2} \\
\mathrm{~N}\end{array}$ & $\begin{array}{c}0.0851 \\
5,294\end{array}$ & $\begin{array}{l}0.100 \\
5,294\end{array}$ & $\begin{array}{l}0.104 \\
5,294\end{array}$ & $\begin{array}{c}0.0163 \\
5,294\end{array}$ & $\begin{array}{c}0.0362 \\
5,294\end{array}$ & $\begin{array}{c}0.0827 \\
5,294\end{array}$ & $\begin{array}{c}0.0954 \\
5,294\end{array}$ & $\begin{array}{c}0.0979 \\
5,294\end{array}$ & $\begin{array}{c}0.0164 \\
5,294\end{array}$ & $\begin{array}{c}0.0362 \\
5,294\end{array}$ \\
\hline
\end{tabular}

This table presents the results of a linear regression model where the dependent variable is the size of the "Wedge" between voting and economic rights for various agents within the firm, as expressed in percentage points. The dependent variable is the wedge for public shareholders in columns (1) and (6), founders in columns (2) and (7), all directors and officers in columns (3) and (8), non-founder directors and officers in columns (4) and (9), and parent or holding company in columns (5) and (10). All specifications include year and two-digit SIC industry fixed effects. All variables are described in the Appendix. All standard errors are robust. ***, **, and $*$ denote significance at the 1\%,5\%, and 10\% levels. Columns (1) through (5) use VC Industry Financing as a proxy for VC investments, while columns (6) through (10) use Industry Dry Powder. 
Table IV

The Determinants of the Wedge - Controlling for "Hot Markets"

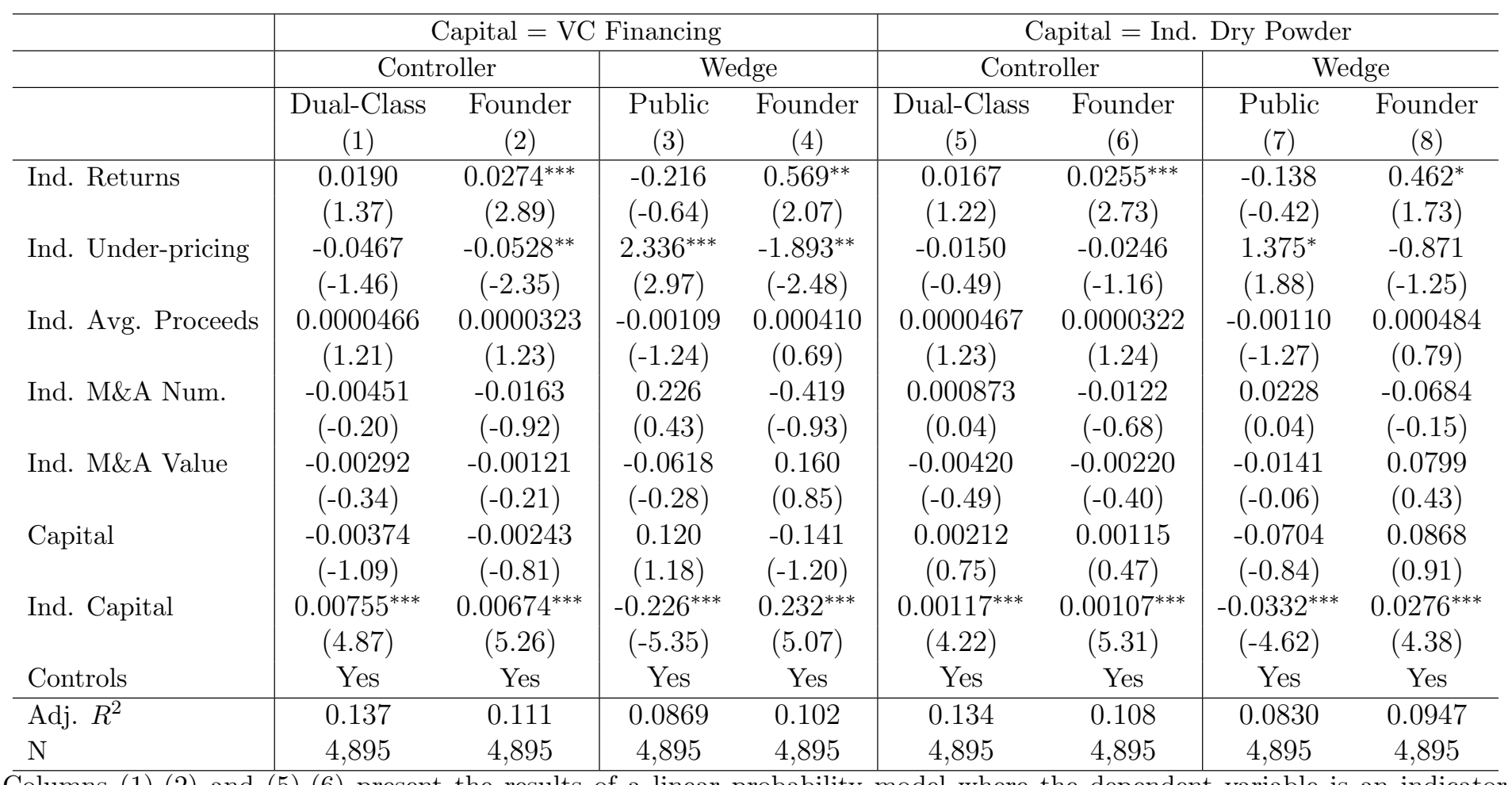

Columns (1)-(2) and (5)-(6) present the results of a linear probability model where the dependent variable is an indicator that equals 1 if an IPO has: dual-class stock in columns (1) and (5), and a founder-controlled dual-class structure in columns (2) and (6). Columns (3)-(4) and (7)-(8) presents the results of a linear regression model where the dependent variable is the size of the "Wedge" between voting and economic rights for various agents within the firm, as expressed in percentage points. The dependent variable is the wedge for public shareholders in columns (3) and (7), and founders in columns (4) and (8). All specifications include year and two-digit SIC industry fixed effects. Financial Controls include ROA, Leverage, Cash, Positive R\&D, and Missing R\&D. All variables are described in the Appendix. All standard errors are robust. ***, **, and * denote significance at the 1\%,5\%, and 10\% levels. Columns (1) through (4) use VC Industry Financing as a proxy for VC investments, while columns (5) through (8) use Industry Dry Powder. 


\section{Table V}

\section{DifFERENT TyPES OF IPOS}

\begin{tabular}{|c|c|c|c|c|c|c|c|c|c|c|c|c|}
\hline & \multicolumn{12}{|c|}{ Panel A: The Determinants of the Controller } \\
\hline & \multicolumn{6}{|c|}{ Dual Class } & \multicolumn{6}{|c|}{ Founder Control } \\
\hline & $\begin{array}{l}\mathrm{VC} \\
(1)\end{array}$ & $\begin{array}{c}\text { Non-VC } \\
(2)\end{array}$ & $\begin{array}{l}\text { Cloud } \\
(3)\end{array}$ & $\begin{array}{l}\text { Non-Cloud } \\
(4)\end{array}$ & $\begin{array}{l}\text { US } \\
(5)\end{array}$ & $\begin{array}{l}\text { Foreign } \\
(6)\end{array}$ & $\begin{array}{l}\mathrm{VC} \\
(7)\end{array}$ & $\begin{array}{c}\text { Non-VC } \\
(8)\end{array}$ & $\begin{array}{l}\text { Cloud } \\
(9)\end{array}$ & $\begin{array}{l}\text { Non-Cloud } \\
(10)\end{array}$ & $\begin{array}{l}\text { US } \\
(11)\end{array}$ & $\begin{array}{l}\text { Foreign } \\
(12)\end{array}$ \\
\hline VC Ind. Financing & $\begin{array}{c}0.00693^{* * *} \\
(4.32)\end{array}$ & $\begin{array}{c}0.00711^{* * * *} \\
(3.35)\end{array}$ & $\begin{array}{c}0.00824^{* * *} \\
(4.98)\end{array}$ & $\begin{array}{c}0.0217^{* *} \\
(2.57) \\
\end{array}$ & $\begin{array}{c}0.00573^{* * *} \\
(4.36)\end{array}$ & $\begin{array}{c}0.00454 \\
(0.90)\end{array}$ & $\begin{array}{c}0.00553^{* * *} \\
(3.89) \\
\end{array}$ & $\begin{array}{c}0.00437^{* * *} \\
(2.88)\end{array}$ & $\begin{array}{c}0.00629^{* * *} \\
(4.59)\end{array}$ & $\begin{array}{c}0.0167^{* * *} \\
(2.88)\end{array}$ & $\begin{array}{c}0.00432^{* * *} \\
(4.35)\end{array}$ & $\begin{array}{c}0.00335 \\
(0.77) \\
\end{array}$ \\
\hline Adj. $R^{2}$ & 0.180 & 0.0977 & 0.166 & 0.0986 & 0.0989 & 0.284 & 0.169 & 0.0755 & 0.162 & 0.0388 & 0.0509 & 0.246 \\
\hline $\mathrm{N}$ & 2,200 & 3,217 & 2,683 & 2,734 & 4,792 & 625 & 2,200 & 3,217 & 2,683 & 2,734 & 4,792 & 625 \\
\hline Ind. Dry Powder & $\begin{array}{c}0.000906^{* * *} \\
(2.99)\end{array}$ & $\begin{array}{c}0.00129^{* * *} \\
(3.56)\end{array}$ & $\begin{array}{c}0.000940^{* * *} \\
(3.20)\end{array}$ & $\begin{array}{c}0.00265^{* * *} \\
(3.26)\end{array}$ & $\begin{array}{c}0.000840^{* * *} \\
(3.64)\end{array}$ & $\begin{array}{c}0.00225^{* * *} \\
(2.75)\end{array}$ & $\begin{array}{c}0.000784^{* * *} \\
\quad(3.36)\end{array}$ & $\begin{array}{c}0.000833^{* * *} \\
(3.46)\end{array}$ & $\begin{array}{c}0.000790^{* * *} \\
(3.63)\end{array}$ & $\begin{array}{c}0.00205^{* * *} \\
(4.17)\end{array}$ & $\begin{array}{c}0.000714^{* * *} \\
(4.37)\end{array}$ & $\begin{array}{c}0.00175^{* * *} \\
(3.01)\end{array}$ \\
\hline \multirow[t]{4}{*}{$\mathrm{N}$} & $\begin{array}{l}0.174 \\
2,200\end{array}$ & $\begin{array}{c}0.0973 \\
3,217\end{array}$ & $\begin{array}{l}0.160 \\
2,683\end{array}$ & $\begin{array}{c}0.0987 \\
2,734\end{array}$ & $\begin{array}{c}0.0968 \\
4,792\end{array}$ & $\begin{array}{c}0.290 \\
625\end{array}$ & $\begin{array}{l}0.163 \\
2,200\end{array}$ & $\begin{array}{c}0.0755 \\
3,217\end{array}$ & $\begin{array}{l}0.156 \\
2,702\end{array}$ & $\begin{array}{c}0.0385 \\
2,782\end{array}$ & $\begin{array}{c}0.0492 \\
4,857\end{array}$ & $\begin{array}{c}0.251 \\
627\end{array}$ \\
\hline & \multicolumn{12}{|c|}{ Panel B: The Determinants of the Wedge } \\
\hline & \multicolumn{6}{|c|}{ Public Wedge } & \multicolumn{6}{|c|}{ Founder Wedge } \\
\hline & $\begin{array}{l}\mathrm{VC} \\
(1) \\
\end{array}$ & $\begin{array}{c}\text { Non- } \mathrm{VC} \\
(2) \\
\end{array}$ & $\begin{array}{c}\text { Cloud } \\
(3)\end{array}$ & $\begin{array}{c}\text { Non-Cloud } \\
(4) \\
\end{array}$ & $\begin{array}{l}\text { US } \\
(5)\end{array}$ & $\begin{array}{c}\text { Foreign } \\
(6)\end{array}$ & $\begin{array}{l}\mathrm{VC} \\
(7) \\
\end{array}$ & $\begin{array}{c}\text { Non-VC } \\
(8)\end{array}$ & $\begin{array}{c}\text { Cloud } \\
(9)\end{array}$ & $\begin{array}{c}\text { Non-Cloud } \\
(10) \\
\end{array}$ & $\begin{array}{c}\text { United States } \\
(11) \\
\end{array}$ & $\begin{array}{c}\text { Foreign } \\
(12) \\
\end{array}$ \\
\hline VC Ind. Financing & $\begin{array}{c}-0.215^{* * *} \\
(-4.35) \\
\end{array}$ & $\begin{array}{c}-0.146^{* * *} \\
(-2.88) \\
\end{array}$ & $\begin{array}{c}-0.224^{* * *} \\
(-4.86) \\
\end{array}$ & $\begin{array}{l}-0.137 \\
(-0.67) \\
\end{array}$ & $\begin{array}{c}-0.177^{* * *} \\
(-4.54) \\
\end{array}$ & $\begin{array}{c}-0.0731 \\
(-0.62) \\
\end{array}$ & $\begin{array}{c}0.190^{* * *} \\
(3.61) \\
\end{array}$ & $\begin{array}{c}0.176^{* * *} \\
(2.85) \\
\end{array}$ & $\begin{array}{c}0.212^{* * *} \\
(4.11) \\
\end{array}$ & $\begin{array}{c}0.350^{* *} \\
(2.53)\end{array}$ & $\begin{array}{c}0.0952^{* * *} \\
(3.53) \\
\end{array}$ & $\begin{array}{c}0.402^{* *} \\
(2.12) \\
\end{array}$ \\
\hline $\begin{array}{l}\text { Adj. } R^{2} \\
\mathrm{~N}\end{array}$ & $\begin{array}{l}0.147 \\
2200\end{array}$ & $\begin{array}{c}0.0667 \\
3217\end{array}$ & $\begin{array}{l}0.107 \\
2683\end{array}$ & $\begin{array}{c}0.0727 \\
2734\end{array}$ & $\begin{array}{c}0.0661 \\
4792\end{array}$ & $\begin{array}{c}0.184 \\
625\end{array}$ & $\begin{array}{l}0.158 \\
2200\end{array}$ & $\begin{array}{c}0.0619 \\
3217\end{array}$ & $\begin{array}{l}0.143 \\
2683\end{array}$ & $\begin{array}{c}0.0258 \\
2734\end{array}$ & $\begin{array}{c}0.0343 \\
4792\end{array}$ & $\begin{array}{c}0.263 \\
625\end{array}$ \\
\hline Ind. Dry Powder & $\begin{array}{c}-0.0286^{* * *} \\
(-3.51)\end{array}$ & $\begin{array}{c}-0.0275^{* * *} \\
(-2.92) \\
\end{array}$ & $\begin{array}{c}-0.0271^{* * *} \\
(-3.38)\end{array}$ & $\begin{array}{c}-0.0465^{* *} \\
(-2.23) \\
\end{array}$ & $\begin{array}{c}-0.0259^{* * *} \\
(-3.87) \\
\end{array}$ & $\begin{array}{c}-0.0451^{* * *} \\
(-2.71)\end{array}$ & $\begin{array}{c}0.0236^{* * *} \\
(3.21) \\
\end{array}$ & $\begin{array}{c}0.0241^{* * *} \\
(2.79) \\
\end{array}$ & $\begin{array}{c}0.0191^{* *} \\
(2.52) \\
\end{array}$ & $\begin{array}{c}0.0494^{* * *} \\
(3.67) \\
\end{array}$ & $\begin{array}{c}0.0145^{* * *} \\
(2.73) \\
\end{array}$ & $\begin{array}{c}0.0409^{* *} \\
(2.21) \\
\end{array}$ \\
\hline Adj. $R^{2}$ & 0.138 & 0.0666 & 0.101 & 0.0738 & 0.0633 & 0.187 & 0.151 & 0.0593 & 0.137 & 0.0267 & 0.0330 & 0.254 \\
\hline $\mathrm{N}$ & 2,200 & 3,217 & 2,683 & 2,734 & 4,792 & 625 & 2,200 & 3,217 & 2,683 & 2,734 & 4,792 & 625 \\
\hline
\end{tabular}

Panel A presents the results of a linear probability model where the dependent variable is an indicator that equals 1 if an IPO has: dual-class stock in columns (1) through (6), and a founder-controlled dual-class structure in columns (7) through (12). We analyze this linear probability model separately for VC and Non-VC backed firms (columns (1)-(2) and (7)-(8)), Cloud and Non-Cloud Industry firms (columns (3)-(4) and (9)-(10)), and U.S. and Foreign firms (columns (5)-(6) and (11)-(12)). The first three rows use VC Industry Financing as a proxy for VC investments, while the next three rows use Industry Dry Powder. Panel B presents the results of a linear regression model where the dependent variable is the size of the "Wedge" between voting and economic rights for various agents within the firm, as expressed in percentage points. The dependent variable is the wedge for public shareholders in columns (1) through (6), and founders in columns (7) through (12). We analyze this linear regression model separately for VC and Non-VC backed firms (columns (1)-(2) and (7)-(8)), Cloud and Non-Cloud Industry firms (columns (3)-(4) and (9)-(10)), and U.S. and Foreign firms (columns (5)-(6) and (11)-(12)). The first three rows use VC Industry Financing as a proxy for VC investments, while the next three rows use Industry Dry Powder. All specifications in this table include year and two-digit SIC industry fixed effects. All variables are described in the Appendix. All standard errors are robust. ***, **, and ${ }^{*}$ denote significance at the 1\%, 5\%, and $10 \%$ levels. 
Table VI

VC-Backed IPOs - The Determinants of the Controller and Wedge

\begin{tabular}{|c|c|c|c|c|c|c|c|c|}
\hline & \multicolumn{4}{|c|}{ Capital = Ind. VC Financing } & \multicolumn{4}{|c|}{ Capital = Ind. Dry Powder } \\
\hline & \multicolumn{2}{|c|}{ Controller } & \multicolumn{2}{|c|}{ Wedge } & \multicolumn{2}{|c|}{ Controller } & \multicolumn{2}{|c|}{ Wedge } \\
\hline & $\begin{array}{c}\text { Dual-Class } \\
(1)\end{array}$ & $\begin{array}{c}\text { Founder } \\
(2)\end{array}$ & $\begin{array}{c}\text { Public } \\
(3)\end{array}$ & $\begin{array}{c}\text { Founder } \\
(4)\end{array}$ & $\begin{array}{c}\text { Dual-Class } \\
(5)\end{array}$ & $\begin{array}{c}\text { Founder } \\
(6)\end{array}$ & $\begin{array}{c}\text { Public } \\
(7)\end{array}$ & $\begin{array}{c}\text { Founder } \\
(8)\end{array}$ \\
\hline Ind. Capital & $\begin{array}{c}0.00442^{* *} \\
(2.55)\end{array}$ & $\begin{array}{c}0.00293^{* *} \\
(2.10)\end{array}$ & $\begin{array}{c}-0.142^{* * *} \\
(-2.91)\end{array}$ & $\begin{array}{c}0.107^{* *} \\
(2.16)\end{array}$ & $\begin{array}{c}0.000625^{*} \\
(1.85)\end{array}$ & $\begin{array}{c}0.000448^{*} \\
(1.82)\end{array}$ & $\begin{array}{c}-0.0195^{* *} \\
(-2.22)\end{array}$ & $\begin{array}{c}0.0144^{*} \\
(1.86)\end{array}$ \\
\hline VC Rounds & $\begin{array}{c}-0.00578^{* *} \\
(-2.24)\end{array}$ & $\begin{array}{c}-0.00795^{* * *} \\
(-4.36)\end{array}$ & $\begin{array}{c}0.180^{* * *} \\
(2.88)\end{array}$ & $\begin{array}{c}-0.182^{\text {*** }} \\
(-3.21)\end{array}$ & $\begin{array}{c}-0.00573^{* *} \\
(-2.23)\end{array}$ & $\begin{array}{c}-0.00792^{* * *} \\
(-4.34)\end{array}$ & $\begin{array}{c}0.178^{* * *} \\
(2.88)\end{array}$ & $\begin{array}{c}-0.180^{* * *} \\
(-3.20)\end{array}$ \\
\hline VC Firms (\#) & $\begin{array}{c}0.000649 \\
(0.44)\end{array}$ & $\begin{array}{c}0.00205^{* *} \\
(2.14)\end{array}$ & $\begin{array}{c}-0.0526 \\
(-1.51)\end{array}$ & $\begin{array}{c}0.0336 \\
(1.23)\end{array}$ & $\begin{array}{c}0.000713 \\
(0.48)\end{array}$ & $\begin{array}{c}0.00208^{* *} \\
(2.17)\end{array}$ & $\begin{array}{r}-0.0547 \\
(-1.57)\end{array}$ & $\begin{array}{c}0.0353 \\
(1.27)\end{array}$ \\
\hline VC Firm Age & $\begin{array}{c}-0.0230^{* *} \\
(-2.10)\end{array}$ & $\begin{array}{c}-0.00661 \\
(-0.83)\end{array}$ & $\begin{array}{l}0.512^{*} \\
(1.78)\end{array}$ & $\begin{array}{l}-0.216 \\
(-1.03)\end{array}$ & $\begin{array}{c}-0.0226^{* *} \\
(-2.07)\end{array}$ & $\begin{array}{c}-0.00641 \\
(-0.80)\end{array}$ & $\begin{array}{l}0.500^{*} \\
(1.74)\end{array}$ & $\begin{array}{l}-0.207 \\
(-0.99)\end{array}$ \\
\hline VC Firm Size & $\begin{array}{c}-0.000536 \\
(-0.12)\end{array}$ & $\begin{array}{c}-0.00486 \\
(-1.23)\end{array}$ & $\begin{array}{c}0.00890 \\
(0.09)\end{array}$ & $\begin{array}{c}-0.0752 \\
(-0.83)\end{array}$ & $\begin{array}{c}-0.000934 \\
(-0.21)\end{array}$ & $\begin{array}{c}-0.00513 \\
(-1.29)\end{array}$ & $\begin{array}{c}0.0217 \\
(0.22)\end{array}$ & $\begin{array}{c}-0.0848 \\
(-0.94)\end{array}$ \\
\hline Cloud Ind. & $\begin{array}{c}-0.0788^{*} \\
(-1.72)\end{array}$ & $\begin{array}{c}-0.0776^{* *} \\
(-2.03)\end{array}$ & $\begin{array}{l}1.476 \\
(1.38)\end{array}$ & $\begin{array}{l}-0.823 \\
(-1.08)\end{array}$ & $\begin{array}{c}-0.0732 \\
(-1.59)\end{array}$ & $\begin{array}{c}-0.0739^{*} \\
(-1.92)\end{array}$ & $\begin{array}{l}1.291 \\
(1.21)\end{array}$ & $\begin{array}{l}-0.683 \\
(-0.89)\end{array}$ \\
\hline Foreign & $\begin{array}{c}0.0603^{* *} \\
(2.23)\end{array}$ & $\begin{array}{c}0.0764^{* * *} \\
\quad(2.92)\end{array}$ & $\begin{array}{l}-0.561 \\
(-0.94)\end{array}$ & $\begin{array}{c}1.744^{* *} \\
(2.19)\end{array}$ & $\begin{array}{c}0.0601^{* *} \\
(2.22)\end{array}$ & $\begin{array}{c}0.0762^{* * *} \\
(2.91)\end{array}$ & $\begin{array}{l}-0.556 \\
(-0.94)\end{array}$ & $\begin{array}{c}1.740^{* *} \\
(2.17)\end{array}$ \\
\hline Eponymous & $\begin{array}{c}-0.00783 \\
(-0.21)\end{array}$ & $\begin{array}{c}0.0253 \\
(0.82)\end{array}$ & $\begin{array}{l}-1.264 \\
(-1.07)\end{array}$ & $\begin{array}{l}0.698 \\
(0.84)\end{array}$ & $\begin{array}{c}-0.0105 \\
(-0.28)\end{array}$ & $\begin{array}{c}0.0236 \\
(0.77)\end{array}$ & $\begin{array}{l}-1.176 \\
(-0.99)\end{array}$ & $\begin{array}{l}0.631 \\
(0.75)\end{array}$ \\
\hline Log(Age) & $\begin{array}{c}0.00585 \\
(0.60)\end{array}$ & $\begin{array}{c}0.00411 \\
(0.57)\end{array}$ & $\begin{array}{l}-0.383 \\
(-1.65)\end{array}$ & $\begin{array}{l}0.322 \\
(1.56)\end{array}$ & $\begin{array}{c}0.00578 \\
(0.59)\end{array}$ & $\begin{array}{c}0.00409 \\
(0.57)\end{array}$ & $\begin{array}{l}-0.380 \\
(-1.64)\end{array}$ & $\begin{array}{l}0.320 \\
(1.55)\end{array}$ \\
\hline Log(Assets) & $\begin{array}{c}0.0507^{\text {*** }} \\
\quad(6.52)\end{array}$ & $\begin{array}{c}0.0295^{* * *} \\
(4.73)\end{array}$ & $\begin{array}{c}-1.034^{* * *} \\
(-4.76)\end{array}$ & $\begin{array}{c}0.948^{* * *} \\
(4.12)\end{array}$ & $\begin{array}{c}0.0510^{* * *} \\
\quad(6.56)\end{array}$ & $\begin{array}{c}0.0297^{* * *} \\
(4.78)\end{array}$ & $\begin{array}{c}-1.046^{\text {*** }} \\
(-4.86)\end{array}$ & $\begin{array}{c}0.957^{* * *} \\
(4.15)\end{array}$ \\
\hline Patents (\$ Mil) & $\begin{array}{c}0.0102^{* *} \\
(2.39)\end{array}$ & $\begin{array}{c}0.0110^{* * *} \\
(2.83)\end{array}$ & $\begin{array}{c}-0.281^{* *} \\
(-2.21)\end{array}$ & $\begin{array}{c}0.300^{* * *} \\
(2.87)\end{array}$ & $\begin{array}{c}0.0102^{* *} \\
(2.41)\end{array}$ & $\begin{array}{c}0.0111^{* * *} \\
(2.85)\end{array}$ & $\begin{array}{c}-0.283^{* *} \\
(-2.23)\end{array}$ & $\begin{array}{c}0.301^{* * *} \\
(2.89)\end{array}$ \\
\hline $\begin{array}{l}\text { Adj. } R^{2} \\
\mathrm{~N}\end{array}$ & $\begin{array}{l}0.159 \\
1,819\end{array}$ & $\begin{array}{l}0.151 \\
1,819\end{array}$ & $\begin{array}{l}0.134 \\
1,819\end{array}$ & $\begin{array}{l}0.122 \\
1,819\end{array}$ & $\begin{array}{l}0.156 \\
1,819\end{array}$ & $\begin{array}{l}0.149 \\
1,819\end{array}$ & $\begin{array}{l}0.131 \\
1,819\end{array}$ & $\begin{array}{l}0.119 \\
1,819\end{array}$ \\
\hline
\end{tabular}

This table only analyzes firms that are VC-backed. Columns (1)-(2) and (5)-(6) present the results of a linear probability model where the dependent variable is an indicator that equals 1 if an IPO has: dual-class stock in columns (1) and (5), and a founder-controlled dual-class structure in columns (2) and (6). Columns (3)-(4) and (7)-(8) presents the results of a linear regression model where the dependent variable is the size of the "Wedge" between voting and economic rights for various agents within the firm, as expressed in percentage points. The dependent variable is the wedge for public shareholders in columns (3) and (7), and founders in columns (4) and (8). All specifications include year and two-digit SIC industry fixed effects. All variables are described in the Appendix. Columns (1) through (4) use VC Industry Financing as a proxy for VC investments, while columns (5) through (8) use Industry Dry Powder. All standard errors are robust. $* * *, * *$, and $*$ denote significance at the $1 \%, 5 \%$, and $10 \%$ levels. 


\section{Table VII}

The Determinants of the Controller and Wedge - Instrumental Variable

\begin{tabular}{|c|c|c|c|c|c|c|c|c|}
\hline & \multicolumn{4}{|c|}{ All IPOs } & \multicolumn{4}{|c|}{ Excl. CA, NY and MA } \\
\hline & \multicolumn{2}{|c|}{ Controller } & \multicolumn{2}{|c|}{ Wedge } & \multicolumn{2}{|c|}{ Controller } & \multicolumn{2}{|c|}{ Wedge } \\
\hline & $\begin{array}{c}\text { Dual-Class } \\
\text { (1) }\end{array}$ & $\begin{array}{c}\text { Founder } \\
(2)\end{array}$ & $\begin{array}{c}\text { Public } \\
(3)\end{array}$ & $\begin{array}{c}\text { Founder } \\
(4)\end{array}$ & $\begin{array}{c}\text { Dual-Class } \\
(5)\end{array}$ & $\begin{array}{c}\text { Founder } \\
(6)\end{array}$ & $\begin{array}{c}\text { Public } \\
(7)\end{array}$ & $\begin{array}{c}\text { Founder } \\
(8)\end{array}$ \\
\hline VC Ind. Financing & $\begin{array}{c}0.00717^{*} \\
(1.90)\end{array}$ & $\begin{array}{c}0.00899^{* * *} \\
(3.33)\end{array}$ & $\begin{array}{c}-0.304^{* * *} \\
(-3.03)\end{array}$ & $\begin{array}{c}0.381^{* * *} \\
(3.74)\end{array}$ & $\begin{array}{c}0.00764 \\
(1.27)\end{array}$ & $\begin{array}{c}0.0116^{* * *} \\
(2.59)\end{array}$ & $\begin{array}{l}-0.300^{*} \\
(-1.92)\end{array}$ & $\begin{array}{c}0.607^{* * *} \\
(3.31)\end{array}$ \\
\hline VC-backed & $\begin{array}{c}-0.00993 \\
(-1.10)\end{array}$ & $\begin{array}{c}0.00743 \\
(1.14)\end{array}$ & $\begin{array}{l}0.238 \\
(1.02)\end{array}$ & $\begin{array}{c}0.0845 \\
(0.41)\end{array}$ & $\begin{array}{c}-0.00147 \\
(-0.12)\end{array}$ & $\begin{array}{c}0.00940 \\
(1.02)\end{array}$ & $\begin{array}{l}0.221 \\
(0.72)\end{array}$ & $\begin{array}{l}0.202 \\
(0.65)\end{array}$ \\
\hline Cloud Ind. & $\begin{array}{c}0.171^{* * *} \\
(3.77)\end{array}$ & $\begin{array}{c}0.0878^{* * *} \\
(3.49)\end{array}$ & $\begin{array}{c}-3.366^{* * *} \\
(-2.98)\end{array}$ & $\begin{array}{c}2.803^{* * *} \\
(2.91)\end{array}$ & $\begin{array}{c}0.221^{* *} \\
(2.56)\end{array}$ & $\begin{array}{c}0.107^{* *} \\
(2.36)\end{array}$ & $\begin{array}{c}-4.416^{* *} \\
(-2.07)\end{array}$ & $\begin{array}{c}3.997^{* *} \\
(2.30)\end{array}$ \\
\hline Foreign & $\begin{array}{c}0.0826^{* * *} \\
(5.24)\end{array}$ & $\begin{array}{c}0.0828^{* * *} \\
(6.42)\end{array}$ & $\begin{array}{c}-0.994^{* *} \\
(-2.49)\end{array}$ & $\begin{array}{c}2.615^{* * *} \\
(5.88)\end{array}$ & $\begin{array}{c}0.0811^{* * *} \\
(4.92)\end{array}$ & $\begin{array}{c}0.0720^{* * *} \\
(5.57)\end{array}$ & $\begin{array}{c}-0.988^{* *} \\
(-2.46)\end{array}$ & $\begin{array}{c}1.890^{* * *} \\
(4.41)\end{array}$ \\
\hline Eponymous & $\begin{array}{c}0.0270 \\
(1.61)\end{array}$ & $\begin{array}{c}0.0276^{* *} \\
(2.35)\end{array}$ & $\begin{array}{c}-1.034^{* *} \\
(-2.08)\end{array}$ & $\begin{array}{l}0.720^{*} \\
(1.74)\end{array}$ & $\begin{array}{c}0.0387^{*} \\
(1.82)\end{array}$ & $\begin{array}{c}0.0256^{*} \\
(1.76)\end{array}$ & $\begin{array}{l}-1.063^{*} \\
(-1.65)\end{array}$ & $\begin{array}{l}0.895 \\
(1.52)\end{array}$ \\
\hline Log(Age) & $\begin{array}{c}-0.00863^{*} \\
(-1.65)\end{array}$ & $\begin{array}{c}-0.0108^{* * *} \\
(-3.44)\end{array}$ & $\begin{array}{l}0.244^{*} \\
(1.70)\end{array}$ & $\begin{array}{c}-0.343^{* * *} \\
(-3.01)\end{array}$ & $\begin{array}{c}-0.00885 \\
(-1.37)\end{array}$ & $\begin{array}{c}-0.0133^{* * *} \\
(-3.43)\end{array}$ & $\begin{array}{l}0.217 \\
(1.21)\end{array}$ & $\begin{array}{c}-0.470^{* * *} \\
(-3.00)\end{array}$ \\
\hline Log(Assets) & $\begin{array}{c}0.0337^{* * *} \\
(10.88)\end{array}$ & $\begin{array}{c}0.00699^{* * *} \\
(3.75)\end{array}$ & $\begin{array}{c}-0.516^{* * *} \\
(-6.62)\end{array}$ & $\begin{array}{c}0.239^{* * *} \\
(3.53)\end{array}$ & $\begin{array}{c}0.0331^{* * *} \\
(9.14)\end{array}$ & $\begin{array}{c}0.00678^{* * *} \\
(2.97)\end{array}$ & $\begin{array}{c}-0.525^{* * *} \\
(-6.01)\end{array}$ & $\begin{array}{c}0.240^{* * *} \\
(2.72)\end{array}$ \\
\hline Patents (\$ Mil) & $\begin{array}{c}0.00607^{*} \\
(1.83)\end{array}$ & $\begin{array}{c}0.00573^{* *} \\
(2.48)\end{array}$ & $\begin{array}{l}-0.119 \\
(-1.41)\end{array}$ & $\begin{array}{c}0.185^{* * *} \\
(2.90)\end{array}$ & $\begin{array}{c}0.00214 \\
(0.47)\end{array}$ & $\begin{array}{c}0.00341 \\
(1.13)\end{array}$ & $\begin{array}{c}-0.0275 \\
(-0.27)\end{array}$ & $\begin{array}{c}0.157^{*} \\
(1.68)\end{array}$ \\
\hline $\begin{array}{l}F-\text { statistic } \\
\text { Adj. } R^{2} \\
\text { N }\end{array}$ & $\begin{array}{l}153.0 \\
0.121 \\
5,383\end{array}$ & $\begin{array}{c}153.0 \\
0.0985 \\
5,383\end{array}$ & $\begin{array}{c}153.0 \\
0.0797 \\
5,383\end{array}$ & $\begin{array}{c}153.0 \\
0.0868 \\
5,383\end{array}$ & $\begin{array}{l}78.81 \\
0.134 \\
3,360\end{array}$ & $\begin{array}{l}78.81 \\
0.118 \\
3,360\end{array}$ & $\begin{array}{c}78.81 \\
0.0909 \\
3,360\end{array}$ & $\begin{array}{l}78.81 \\
0.108 \\
3,360\end{array}$ \\
\hline
\end{tabular}

Columns (1)-(2) and (5)-(6) present the results of an instrumental variables analysis where the dependent variable is an indicator that equals 1 if an IPO has: dual-class stock in columns (1) and (5), and a founder-controlled dual-class structure in columns (2) and (6). Columns (3)-(4) and (7)-(8) presents the results of an instrumental variables analysis where the dependent variable is the size of the

"Wedge" between voting and economic rights for various agents within the firm, as expressed in percentage points. The dependent variable is the wedge for public shareholders in columns (3) and (7), and founders in columns (4) and (8). All specifications include year and two-digit SIC industry fixed effects. All variables are described in the Appendix. Columns (1) through (4) examine all IPO firms between 1994 to 2019, while columns (5) through (8) exclude firms headquartered in California, New York, and Massachusetts. All standard errors are robust. $* * *, * *$, and $*$ denote significance at the $1 \%, 5 \%$, and $10 \%$ levels. 


\section{Table VIII}

The Determinants of the Controller and Wedge - Trends Over Time

\begin{tabular}{|c|c|c|c|c|c|c|c|c|}
\hline & \multicolumn{4}{|c|}{ Controller } & \multicolumn{4}{|c|}{ Wedge } \\
\hline & \multicolumn{2}{|c|}{ Dual-Class } & \multicolumn{2}{|c|}{ Founder } & \multicolumn{2}{|c|}{ Public } & \multicolumn{2}{|c|}{ Founder } \\
\hline & (1) & $(2)$ & $(3)$ & (4) & (5) & (6) & $(7)$ & (8) \\
\hline VC-backed & $\begin{array}{c}-0.0419^{* * *} \\
(-3.87)\end{array}$ & $\begin{array}{c}-0.0362^{* *} \\
(-2.50)\end{array}$ & $\begin{array}{c}-0.0179^{* * *} \\
(-2.59)\end{array}$ & $\begin{array}{c}-0.0141 \\
(-1.49)\end{array}$ & $\begin{array}{c}1.061^{* * *} \\
(3.72)\end{array}$ & $\begin{array}{c}0.820^{* *} \\
(2.20)\end{array}$ & $\begin{array}{c}-0.411^{* *} \\
(-2.06)\end{array}$ & $\begin{array}{l}-0.162 \\
(-0.65)\end{array}$ \\
\hline VC-backed post-2005 & $\begin{array}{c}0.1000^{* * *} \\
(5.38)\end{array}$ & $\begin{array}{c}0.0816^{* * *} \\
(3.96)\end{array}$ & $\begin{array}{c}0.0775^{* * *} \\
(5.32)\end{array}$ & $\begin{array}{c}0.0294^{* *} \\
(2.17)\end{array}$ & $\begin{array}{c}-2.717^{* * *} \\
(-5.44)\end{array}$ & $\begin{array}{c}-1.744^{* * *} \\
(-3.42)\end{array}$ & $\begin{array}{c}1.706^{* * *} \\
(3.37)\end{array}$ & $\begin{array}{c}0.788^{* *} \\
(1.96)\end{array}$ \\
\hline Cloud Ind. & $\begin{array}{c}0.158^{* * *} \\
(3.17)\end{array}$ & $\begin{array}{c}0.163^{* * *} \\
(3.10)\end{array}$ & $\begin{array}{c}0.0756^{* * *} \\
(2.78)\end{array}$ & $\begin{array}{c}0.0856^{* * *} \\
(2.80)\end{array}$ & $\begin{array}{c}-3.314^{* *} \\
(-2.46)\end{array}$ & $\begin{array}{c}-3.531^{* *} \\
(-2.47)\end{array}$ & $\begin{array}{c}2.630^{* *} \\
(2.20)\end{array}$ & $\begin{array}{c}2.882^{* *} \\
(2.21)\end{array}$ \\
\hline Cloud Ind. post-2005 & $\begin{array}{c}0.109^{* * *} \\
(5.79)\end{array}$ & $\begin{array}{c}0.0574^{* *} \\
(2.25)\end{array}$ & $\begin{array}{c}0.0836^{* * *} \\
(5.90)\end{array}$ & $\begin{array}{c}-0.000962 \\
(-0.06)\end{array}$ & $\begin{array}{c}-2.313^{* * *} \\
(-4.70)\end{array}$ & $\begin{array}{l}-0.877 \\
(-1.40)\end{array}$ & $\begin{array}{c}2.187^{* * *} \\
(4.61)\end{array}$ & $\begin{array}{c}-0.0655 \\
(-0.12)\end{array}$ \\
\hline Foreign & $\begin{array}{c}-0.0316^{*} \\
(-1.70)\end{array}$ & $\begin{array}{c}-0.0487^{*} \\
(-1.86)\end{array}$ & $\begin{array}{c}-0.00539 \\
(-0.42)\end{array}$ & $\begin{array}{c}-0.0152 \\
(-0.88)\end{array}$ & $\begin{array}{c}1.108^{* *} \\
(2.43)\end{array}$ & $\begin{array}{l}1.190^{*} \\
(1.65)\end{array}$ & $\begin{array}{l}-0.294 \\
(-0.98)\end{array}$ & $\begin{array}{c}-0.597^{*} \\
(-1.75)\end{array}$ \\
\hline Foreign post-2005 & $\begin{array}{c}0.208^{* * *} \\
(7.15)\end{array}$ & $\begin{array}{c}0.127^{* * *} \\
(3.49)\end{array}$ & $\begin{array}{c}0.159^{* * *} \\
(6.80)\end{array}$ & $\begin{array}{c}0.0603^{* *} \\
(2.37)\end{array}$ & $\begin{array}{c}-3.988^{* * *} \\
(-5.46)\end{array}$ & $\begin{array}{c}-2.550^{* * *} \\
(-2.78)\end{array}$ & $\begin{array}{c}5.529^{* * *} \\
(6.67)\end{array}$ & $\begin{array}{c}1.963^{* * *} \\
(2.82)\end{array}$ \\
\hline Media & $\begin{array}{c}0.0709^{* *} \\
(2.41)\end{array}$ & $\begin{array}{c}0.0664^{* *} \\
(2.26)\end{array}$ & $\begin{array}{c}0.0301^{*} \\
(1.87)\end{array}$ & $\begin{array}{c}0.0236 \\
(1.48)\end{array}$ & $\begin{array}{c}-1.405^{* *} \\
(-2.06)\end{array}$ & $\begin{array}{c}-1.296^{*} \\
(-1.90)\end{array}$ & $\begin{array}{l}0.452 \\
(1.10)\end{array}$ & $\begin{array}{l}0.261 \\
(0.65)\end{array}$ \\
\hline Media post-2005 & $\begin{array}{c}-0.144^{* * *} \\
(-3.12)\end{array}$ & $\begin{array}{c}-0.134^{* * *} \\
(-2.92)\end{array}$ & $\begin{array}{c}-0.0970^{* * *} \\
(-3.32)\end{array}$ & $\begin{array}{c}-0.0830^{* * *} \\
(-2.94)\end{array}$ & $\begin{array}{c}3.055^{* * *} \\
(2.85)\end{array}$ & $\begin{array}{c}2.834^{* * *} \\
(2.65)\end{array}$ & $\begin{array}{c}-2.566^{* * *} \\
(-3.62)\end{array}$ & $\begin{array}{c}-2.142^{* * *} \\
(-3.20)\end{array}$ \\
\hline Eponymous & $\begin{array}{c}0.0279^{*} \\
(1.65)\end{array}$ & $\begin{array}{c}0.0279 \\
(1.64)\end{array}$ & $\begin{array}{c}0.0289^{* *} \\
(2.44)\end{array}$ & $\begin{array}{c}0.0294^{* *} \\
(2.50)\end{array}$ & $\begin{array}{c}-1.073^{* *} \\
(-2.12)\end{array}$ & $\begin{array}{c}-1.082^{* *} \\
(-2.13)\end{array}$ & $\begin{array}{c}0.735^{*} \\
(1.76)\end{array}$ & $\begin{array}{c}0.737^{*} \\
(1.77)\end{array}$ \\
\hline Log(Age) & $\begin{array}{c}-0.00601 \\
(-1.11)\end{array}$ & $\begin{array}{c}-0.00603 \\
(-1.12)\end{array}$ & $\begin{array}{c}-0.00962^{* * *} \\
(-2.97)\end{array}$ & $\begin{array}{c}-0.00974^{* * *} \\
(-3.03)\end{array}$ & $\begin{array}{l}0.286^{*} \\
(1.89)\end{array}$ & $\begin{array}{l}0.289^{*} \\
(1.90)\end{array}$ & $\begin{array}{c}-0.393^{* * *} \\
(-3.28)\end{array}$ & $\begin{array}{c}-0.394^{* * *} \\
(-3.30)\end{array}$ \\
\hline Log(Assets) & $\begin{array}{c}0.0391^{* * *} \\
(10.92)\end{array}$ & $\begin{array}{c}0.0392^{* * *} \\
(10.89)\end{array}$ & $\begin{array}{c}0.00679^{* * *} \\
\quad(3.09)\end{array}$ & $\begin{array}{c}0.00675^{* * *} \\
\quad(3.07)\end{array}$ & $\begin{array}{c}-0.595^{* * *} \\
(-6.36)\end{array}$ & $\begin{array}{c}-0.596^{* * *} \\
(-6.34)\end{array}$ & $\begin{array}{c}0.245^{* * *} \\
(2.98)\end{array}$ & $\begin{array}{c}0.248^{* * *} \\
(3.00)\end{array}$ \\
\hline Patents $(\$)$ & $\begin{array}{c}0.00545 \\
(1.57)\end{array}$ & $\begin{array}{c}0.00492 \\
(1.41)\end{array}$ & $\begin{array}{c}0.00582^{* *} \\
(2.43)\end{array}$ & $\begin{array}{c}0.00531^{* *} \\
(2.21)\end{array}$ & $\begin{array}{l}-0.110 \\
(-1.25)\end{array}$ & $\begin{array}{l}-0.102 \\
(-1.15)\end{array}$ & $\begin{array}{c}0.200^{* * *} \\
(3.01)\end{array}$ & $\begin{array}{c}0.179^{* * *} \\
(2.69)\end{array}$ \\
\hline VC-backed Cloud Ind. & & $\begin{array}{c}-0.00711 \\
(-0.37)\end{array}$ & & $\begin{array}{c}-0.00263 \\
(-0.21)\end{array}$ & & $\begin{array}{l}0.411 \\
(0.83)\end{array}$ & & $\begin{array}{l}-0.328 \\
(-0.94)\end{array}$ \\
\hline VC-backed Cloud Ind. post-2005 & & $\begin{array}{c}0.0325 \\
(0.88)\end{array}$ & & $\begin{array}{c}0.0932^{* * *} \\
(3.26)\end{array}$ & & $\begin{array}{c}-1.915^{* *} \\
(-1.98)\end{array}$ & & $\begin{array}{l}1.665^{*} \\
(1.72)\end{array}$ \\
\hline Foreign Cloud Ind. & & $\begin{array}{c}0.0353 \\
(0.95)\end{array}$ & & $\begin{array}{c}0.0203 \\
(0.78)\end{array}$ & & $\begin{array}{l}-0.187 \\
(-0.21)\end{array}$ & & $\begin{array}{l}0.596 \\
(0.97)\end{array}$ \\
\hline Foreign Cloud Ind. post-2005 & & $\begin{array}{c}0.145^{* *} \\
(2.51)\end{array}$ & & $\begin{array}{c}0.178^{* * *} \\
(3.86)\end{array}$ & & $\begin{array}{c}-2.560^{*} \\
(-1.79)\end{array}$ & & $\begin{array}{c}6.504^{* * *} \\
(4.19)\end{array}$ \\
\hline Financial Controls & Yes & Yes & Yes & Yes & Yes & Yes & Yes & Yes \\
\hline Adj. $R^{2}$ & 0.148 & 0.152 & 0.123 & 0.136 & 0.0933 & 0.0949 & 0.108 & 0.121 \\
\hline $\mathrm{N}$ & 5,294 & 5,294 & 5,294 & 5,294 & 5,294 & 5,294 & 5,294 & 5,294 \\
\hline
\end{tabular}

Columns (1)-(4) present the results of a linear probability model where the dependent variable is an indicator that equals 1 if an IPO has: dual-class stock in columns (1) and (2), and a founder-controlled dual-class structure in columns (3) and (4). Columns (5)-(8) present the results of a linear regression model where the dependent variable is the size of the "Wedge" between voting and economic rights for various agents within the firm, as expressed in percentage points. The dependent variable is the wedge for public shareholders in columns (5) and (6), and founders in columns (7) and (8). All specifications include year and two-digit SIC industry fixed effects. Financial Controls include ROA, Leverage, Cash, Positive R\&D, and Missing R\&D. All variables are described in the Appendix. All standard errors are robust. $* * *, * *$, and $*$ denote significance at the $1 \%, 5 \%$, and $10 \%$ levels. 


\section{Table IX}

The Costs of Doing Business for IPO fiRms After 2005

\begin{tabular}{|c|c|c|c|c|c|c|}
\hline & \multicolumn{3}{|c|}{ Cost of Goods } & \multicolumn{3}{|c|}{ General Expenses } \\
\hline & (1) & $(2)$ & (3) & (4) & (5) & (6) \\
\hline Cloud Ind. & $\begin{array}{c}0.0883 \\
(1.11)\end{array}$ & $\begin{array}{l}0.101 \\
(1.12)\end{array}$ & $\begin{array}{c}0.0712 \\
(0.70)\end{array}$ & $\begin{array}{c}0.300^{* * *} \\
(2.94)\end{array}$ & $\begin{array}{c}0.188^{* *} \\
(2.10)\end{array}$ & $\begin{array}{l}-0.112 \\
(-1.03)\end{array}$ \\
\hline Cloud Ind. post-2005 & $\begin{array}{c}-0.0823^{* * *} \\
(-3.41)\end{array}$ & $\begin{array}{c}-0.0809^{* * *} \\
(-3.37)\end{array}$ & $\begin{array}{c}-0.0703^{* * *} \\
(-3.07)\end{array}$ & $\begin{array}{c}-0.128^{* * *} \\
(-4.19)\end{array}$ & $\begin{array}{c}-0.0943^{* * *} \\
(-3.22)\end{array}$ & $\begin{array}{c}-0.0555^{* * *} \\
(-2.66)\end{array}$ \\
\hline Eponymous & & $\begin{array}{c}-0.00755 \\
(-0.52)\end{array}$ & $\begin{array}{c}-0.00696 \\
(-0.50)\end{array}$ & & $\begin{array}{c}-0.00838 \\
(-0.48)\end{array}$ & $\begin{array}{c}0.0194^{*} \\
(1.66)\end{array}$ \\
\hline Log(Age) & & $\begin{array}{c}-0.0217^{* * *} \\
(-3.81)\end{array}$ & $\begin{array}{c}-0.00815 \\
(-1.53)\end{array}$ & & $\begin{array}{c}-0.0505^{* * *} \\
(-6.74)\end{array}$ & $\begin{array}{c}-0.00953^{*} \\
(-1.77)\end{array}$ \\
\hline Log(Assets) & & $\begin{array}{c}0.00392 \\
(1.14)\end{array}$ & $\begin{array}{c}0.0123^{* * *} \\
(3.41)\end{array}$ & & $\begin{array}{c}-0.0599^{* * *} \\
(-13.19)\end{array}$ & $\begin{array}{c}-0.0203^{* * *} \\
(-5.17)\end{array}$ \\
\hline Leverage & & & $\begin{array}{c}-0.0000130 \\
(-0.00)\end{array}$ & & & $\begin{array}{c}0.0104^{* *} \\
(2.41)\end{array}$ \\
\hline Cash & & & $\begin{array}{c}0.00455 \\
(0.25)\end{array}$ & & & $\begin{array}{l}0.0101 \\
(0.48)\end{array}$ \\
\hline Positive R\&D & & & $\begin{array}{c}0.208^{* * *} \\
(5.26)\end{array}$ & & & $\begin{array}{c}0.603^{* * *} \\
(14.05)\end{array}$ \\
\hline Missing R\&D & & & $\begin{array}{c}-0.210^{* * *} \\
(-8.96)\end{array}$ & & & $\begin{array}{c}0.106^{* * *} \\
(3.38)\end{array}$ \\
\hline ROA & & & $\begin{array}{c}-0.0464^{* *} \\
(-2.31)\end{array}$ & & & $\begin{array}{l}-0.0130 \\
(-0.46)\end{array}$ \\
\hline PPE & & & $\begin{array}{c}-0.260^{* * *} \\
(-8.68)\end{array}$ & & & $\begin{array}{c}-0.734^{* * *} \\
(-15.26)\end{array}$ \\
\hline Patents ( $\$$ mil) & & & $\begin{array}{c}-0.0944^{* * *} \\
(-3.14)\end{array}$ & & & $\begin{array}{c}-0.0177 \\
(-0.57)\end{array}$ \\
\hline Adj. $R^{2}$ & 0.232 & 0.232 & 0.305 & 0.264 & 0.315 & 0.643 \\
\hline $\mathrm{N}$ & 4,312 & 4,301 & 4,226 & 3,765 & 3,757 & 3,718 \\
\hline
\end{tabular}

This table presents the results of a linear regression model where the dependent variable is Costs of Goods in columns (1) through (3) and General Expenses in columns (4) through (6). Costs of Goods and General Expenses are winsorized at the 1\% level. All specifications include year and two-digit SIC industry fixed effects. All variables are described in the Appendix. All standard errors are robust. ***, **, and ${ }^{*}$ denote significance at the $1 \%, 5 \%$, and $10 \%$ levels. 
Table X

The Likelihood of Sunset Provisions in Dual-Class IPOs

\begin{tabular}{lcccc}
\hline & Time Sunset & Ownership Sunset & Transfer Sunset & Other Sunsets \\
& $(1)$ & $(2)$ & $(3)$ & $(4)$ \\
\hline Founder-control post-2005 & $-0.162^{* *}$ & $-0.176^{*}$ & 0.0106 & -0.0579 \\
& $(-2.22)$ & $(-1.76)$ & $(0.09)$ & $(-0.68)$ \\
Founder-control & 0.0274 & 0.0229 & 0.115 & 0.0638 \\
& $(0.54)$ & $(0.33)$ & $(1.26)$ & $(0.98)$ \\
Post-2005 & $0.175^{* *}$ & $0.364^{* * *}$ & $0.555^{* * *}$ & 0.127 \\
& $(2.23)$ & $(3.20)$ & $(3.78)$ & $(1.23)$ \\
Founder-control Non-Cloud & 0.00482 & -0.0435 & -0.0549 & -0.0209 \\
Non-Cloud post-2005 & $(0.08)$ & $(-0.49)$ & $(-0.46)$ & $(-0.27)$ \\
& 0.113 & $-0.309^{* * *}$ & $-0.302^{* *}$ & 0.0827 \\
Founder-control Non-Cloud post-2005 & $(1.33)$ & $(-2.64)$ & $(-2.32)$ & $(0.85)$ \\
& -0.0564 & $0.403^{* *}$ & 0.221 & -0.119 \\
VC-backed & $(-0.47)$ & $(2.27)$ & $(1.18)$ & $(-0.83)$ \\
Log(Age) & $0.0660^{* *}$ & -0.00516 & -0.0615 & 0.0371 \\
& $(2.31)$ & $(-0.12)$ & $(-1.22)$ & $(1.02)$ \\
\hline Adj. $R^{2}$ & 0.0140 & $0.0339^{*}$ & -0.0262 & $0.0243^{*}$ \\
N & $(1.29)$ & $(1.77)$ & $(-1.19)$ & $(1.73)$ \\
\hline
\end{tabular}

This table presents the results of a linear regression model where the dependent variable is one of the four types of sunset provisions: (1) Time Sunset, (2) Ownership Sunset, (3) Transfer Sunset, and (4) Other Sunset. All specifications include year and two-digit SIC industry fixed effects. All variables are described in the Appendix. All standard errors are robust. ${ }^{* * *},{ }^{* *}$, and $*$ denote significance at the $1 \%, 5 \%$, and $10 \%$ levels. 


\section{Table XI}

Tobin's Q And the Size of the Wedge

\begin{tabular}{|c|c|c|c|c|c|}
\hline & (1) & $(2)$ & (3) & (4) & (5) \\
\hline Founder Wedge & $\begin{array}{c}0.000842 \\
(0.18)\end{array}$ & $\begin{array}{c}0.0424^{* * *} \\
(2.87)\end{array}$ & $\begin{array}{c}0.0589^{* * *} \\
(3.63)\end{array}$ & $\begin{array}{c}0.0741^{* * *} \\
(3.44)\end{array}$ & $\begin{array}{c}0.0527^{* * *} \\
(2.65)\end{array}$ \\
\hline${\text { (Founder Wedge })^{2}}^{2}$ & & $\begin{array}{c}-0.000846^{* * *} \\
(-3.19)\end{array}$ & $\begin{array}{c}-0.00112^{* * *} \\
(-3.93)\end{array}$ & $\begin{array}{c}-0.00140^{* * *} \\
(-3.41)\end{array}$ & $\begin{array}{c}-0.00114^{* * *} \\
(-3.06)\end{array}$ \\
\hline Public Wedge & & & & $\begin{array}{c}-0.00311 \\
(-0.32)\end{array}$ & $\begin{array}{c}-0.0102 \\
(-1.20)\end{array}$ \\
\hline$(\text { Public Wedge })^{2}$ & & & & $\begin{array}{c}0.0000353 \\
\quad(0.24)\end{array}$ & $\begin{array}{c}0.000122 \\
(0.97)\end{array}$ \\
\hline D\&O Wedge & & & & $\begin{array}{c}-0.0206 \\
(-1.13)\end{array}$ & $\begin{array}{c}-0.0133 \\
(-0.80)\end{array}$ \\
\hline$(\mathrm{D} \& \mathrm{O} \text { Wedge })^{2}$ & & & & $\begin{array}{c}0.000300 \\
(0.76)\end{array}$ & $\begin{array}{c}0.000151 \\
(0.42)\end{array}$ \\
\hline Company Wedge & & & & $\begin{array}{c}-0.00437 \\
(-0.13)\end{array}$ & $\begin{array}{c}0.0589^{*} \\
(1.83)\end{array}$ \\
\hline${\text { (Company Wedge })^{2}}^{2}$ & & & & $\begin{array}{c}-0.000110 \\
(-0.14)\end{array}$ & $\begin{array}{c}-0.00165^{* *} \\
(-2.19)\end{array}$ \\
\hline Log(Age) & & & & & $\begin{array}{c}-0.138^{* * *} \\
(-3.20)\end{array}$ \\
\hline Log(Assets) & & & & & $\begin{array}{c}-0.308^{* * *} \\
(-11.46)\end{array}$ \\
\hline Patents ( $\$$ milllion) & & & & & $\begin{array}{c}0.347^{* * *} \\
(9.23)\end{array}$ \\
\hline Leverage & & & & & $\begin{array}{l}-0.180 \\
(-1.28)\end{array}$ \\
\hline Cash & & & & & $\begin{array}{c}0.813^{* * *} \\
(4.10)\end{array}$ \\
\hline Positive R\&D & & & & & $\begin{array}{c}0.424^{* *} \\
(2.41)\end{array}$ \\
\hline Missing R\&D & & & & & $\begin{array}{l}-0.127 \\
(-0.88)\end{array}$ \\
\hline Fixed Effects & Year, Ind. & Year, Ind. & Year-Ind. & Year-Ind. & Year-Ind. \\
\hline Adj. $R^{2}$ & 0.244 & 0.246 & 0.235 & 0.235 & 0.321 \\
\hline $\mathrm{N}$ & 5,167 & 5,167 & 5,167 & 5,167 & 5,052 \\
\hline
\end{tabular}


Table XII

Price-to-Book Ratio and the Size of the Wedge

\begin{tabular}{|c|c|c|c|c|c|}
\hline & (1) & $(2)$ & (3) & (4) & (5) \\
\hline Founder Wedge & $\begin{array}{c}0.00216 \\
(024)\end{array}$ & $\begin{array}{c}0.0552^{* *} \\
(204)\end{array}$ & $\begin{array}{c}0.0695^{* *} \\
(231)\end{array}$ & $0.0768^{*}$ & $\begin{array}{l}0.0551 \\
(1.32)\end{array}$ \\
\hline${\text { (Founder Wedge })^{2}}^{2}$ & & $\begin{array}{c}-0.00108^{* *} \\
(-2.03)\end{array}$ & $\begin{array}{c}-0.00140^{* *} \\
(-2.40)\end{array}$ & $\begin{array}{c}-0.00174^{*} \\
(-1.94)\end{array}$ & $\begin{array}{c}-0.00141^{*} \\
(-1.69)\end{array}$ \\
\hline Public Wedge & & & & $\begin{array}{c}-0.0264 \\
(-1.53)\end{array}$ & $\begin{array}{c}-0.0309^{*} \\
(-1.87)\end{array}$ \\
\hline$(\text { Public Wedge })^{2}$ & & & & $\begin{array}{c}0.000442 \\
(1.60)\end{array}$ & $\begin{array}{c}0.000431 \\
(1.63)\end{array}$ \\
\hline D\&O Wedge & & & & $\begin{array}{c}-0.0354 \\
(-0.94)\end{array}$ & $\begin{array}{c}-0.0261 \\
(-0.76)\end{array}$ \\
\hline$(\mathrm{D} \& \mathrm{O} \text { Wedge })^{2}$ & & & & $\begin{array}{c}0.000136 \\
(0.15)\end{array}$ & $\begin{array}{c}-0.0000345 \\
\quad(-0.04)\end{array}$ \\
\hline Company Wedge & & & & $\begin{array}{c}0.0296 \\
(0.44)\end{array}$ & $\begin{array}{c}0.0460 \\
(0.72)\end{array}$ \\
\hline$(\text { Company Wedge })^{2}$ & & & & $\begin{array}{c}-0.00193 \\
(-1.19)\end{array}$ & $\begin{array}{c}-0.00227 \\
(-1.51)\end{array}$ \\
\hline Log(Age $)$ & & & & & $\begin{array}{l}-0.140^{*} \\
(-1.74)\end{array}$ \\
\hline Log(Assets) & & & & & $\begin{array}{c}-0.178^{* * *} \\
(-3.51)\end{array}$ \\
\hline Patents ( $\$$ milllion) & & & & & $\begin{array}{c}0.515^{* * *} \\
(7.58)\end{array}$ \\
\hline Leverage & & & & & $\begin{array}{c}0.597^{* *} \\
(2.21)\end{array}$ \\
\hline Cash & & & & & $\begin{array}{c}0.846^{* *} \\
(2.46)\end{array}$ \\
\hline Positive R\&D & & & & & $\begin{array}{l}0.513 \\
(1.42)\end{array}$ \\
\hline Missing R\&D & & & & & $\begin{array}{l}-0.259 \\
(-0.84)\end{array}$ \\
\hline Fixed Effects & Year, Ind. & Year, Ind. & Year-Ind. & Year-Ind. & Year-Ind. \\
\hline Adj. $R^{2}$ & 0.167 & 0.168 & 0.179 & 0.180 & 0.218 \\
\hline $\mathrm{N}$ & 5,167 & 5,167 & 5,167 & 5,167 & 5,052 \\
\hline
\end{tabular}

This table presents the results of a linear regression model where the dependent variable is Price-to-Book Ratio (winsorized at the $2.5 \%$ level). All specifications include year and twodigit SIC industry fixed effects. All variables are described in the Appendix. All standard errors are robust. ${ }^{* * *},{ }^{* *}$, and ${ }^{*}$ denote significance at the $1 \%, 5 \%$, and $10 \%$ levels. 


\section{APPENDIX}

\section{VARIABLE DESCRIPTION}

\begin{tabular}{|c|c|c|}
\hline Variable & Definition & Source \\
\hline Age & The difference between the current year and the year the company was founded & Compustat; Jay Ritter's website \\
\hline Assets & Book value of assets in $\$$ millions & Compustat \\
\hline Cash & The ratio of cash and short-term investments to total book assets & Compustat \\
\hline Cloud Ind. & $\begin{array}{l}\text { An indicator equal to } 1 \text { if a firm belongs to one of the following two-digit SIC codes: } 23,27,31,51,52,53,54 \\
56,57,58,59,60,61,62,63,64,65,67,70,73,78,79,82,87 \text {, and } 93\end{array}$ & Ewens et al. (2018); Compustat \\
\hline Co. Control & An indicator equal to 1 if a parent or holding company controls the firm and has the most voting power & Manual checks \\
\hline Co. Wedge & The difference between parent or holding company's voting rights and economic rights & Manual checks \\
\hline Cost of Goods & Cost of goods divided by sales & Compustat \\
\hline D\&O Wedge & The difference between directors and officers' voting rights and economic rights & Manual checks \\
\hline Dual-class & An indicator equal to 1 if a firm has dual-class stock at the time of its IPO & $\begin{array}{l}\text { Manual checks; Jay Ritter's website; } \\
\text { Gompers et al. (2009) }\end{array}$ \\
\hline Eponymous & An indicator equal to 1 if a firm's name at IPO includes a person's name & Manual checks; Gompers et al. (2009) \\
\hline Founder Control & An indicator equal to 1 if the founder controls the firm and has the most voting power & Manual checks \\
\hline Founder Wedge & The difference between founders' voting rights and economic rights & Manucal checks \\
\hline General Expenses & Selling, general and administrative expense divided by sales & Compustat \\
\hline Ind. Dry Powder & $\begin{array}{l}\text { The amount of funds in } \$ \text { billions raised by VC firms, but not invested in any company allocated to each } \\
\text { two-digit SIC industry code based on the number of the fund's investment in each industry }\end{array}$ & VentureXpert \\
\hline Ind. M\&A Num. & $\begin{array}{l}\text { The natural log of the the number of industry mergers and acquistions in the year prior to the firm's IPO based } \\
\text { on two-digit industry codes }\end{array}$ & $\mathrm{SDC}$ \\
\hline Ind. M\&A Value & $\begin{array}{l}\text { The natural log of the value of industry mergers and acquistions in the year prior to the firm's IPO based on } \\
\text { two-digit industry codes }\end{array}$ & SDC \\
\hline Ind. Returns & $\begin{array}{l}\text { The annual returns to the industry portfolio in the year prior to the firm's IPO based on the Fama-French } 48 \\
\text { industry classification }\end{array}$ & Ken French website \\
\hline Ind. Under-pricing & $\begin{array}{l}\text { The average under-pricing of IPOs in the industry in the year prior to the firm's IPO based on the Fama-French } \\
48 \text { industry classification. Under-pricing is the price of the share at the close of the first day of trading minus } \\
\text { the offer price at the IPO divided by the offer price at the IPO }\end{array}$ & CRSP; SDC \\
\hline Ind. Avg. Proceeds & $\begin{array}{l}\text { The average proceeds of IPOs in the industry in the year prior to the firm's IPO based on the Fama-French } 48 \\
\text { industry classification }\end{array}$ & SDC \\
\hline Leverage & The ratio of long-term debt to total book assets & Compustat \\
\hline Missing R\&D & An indicator equal to 1 if $R \& D$ is missing & Compustat \\
\hline NF D\&O Control & An indicator equal to 1 if a non-founder director or officer controls the firm and has the most voting power & Manual checks \\
\hline NF D\&O Wedge & The difference between non-founder directors and officers' voting rights and economic rights & Manual checks \\
\hline NF Dual & An indicator equal to 1 if someone other than a founder controls the firm and has the most voting power & Manual checks \\
\hline Non-Cloud & An indicator equal to 1 if a firm does not belong to a Cloud Industry & Compustat \\
\hline Other Sunset & $\begin{array}{l}\text { Sunset provisions other than Ownership Sunsets, Time Sunsets, or Transfer Sunsets that cause supervoting } \\
\text { shares to convert into shares with just one vote on the occurence of a specified event, such as the } \\
\text { controller's death or disability }\end{array}$ & Manual checks \\
\hline Ownership Sunset & $\begin{array}{l}\text { Sunset provisions that cause supervoting shares to convert into shares with just one vote when the } \\
\text { controller owns less than a prespecified percentage of the company's shares }\end{array}$ & Manual Checks \\
\hline Patents (\$ mil) & $\begin{array}{l}\text { The sum of the real economic value of innovation measured as the value of all patents filed by an IPO firm } \\
\text { within the five years before the IPO date. The file date is the synthetic file date obtained from the issue } \\
\text { date minus } 1,017 \text { days }\end{array}$ & Kogan et. al (2017) \\
\hline PPE & Net property, plant and equipment divided by total book assets & Compustat \\
\hline Price-to-Book Ratio & $\begin{array}{l}\text { Market value of equity divided by book equity defined as in Fama \& French (1992). Market value of equity } \\
\text { is defined as the fiscal year end close price times the number of shares outstanding as of the first year } \\
\text { following the IPO }\end{array}$ & Compustat; CRSP; SDC \\
\hline Proceeds & Proceeds in $\$$ millions raised in the IPO of the firm & SDC \\
\hline Public Wedge & The difference between outside public shareholders' voting rights and economic rights & Manual checks \\
\hline $\mathbf{R} \& \mathbf{D}$ & The ratio of research and development expenditures over total book assets & Compustat \\
\hline ROA & Return on assets calculated as operating income after depreciation divided by book assets in the previous year & Compustat \\
\hline Spin-off & An indicator equal to 1 if the IPO involves a spin-off of a subsidiary corporation & SDC \\
\hline Time Sunset & Sunsets provisions that cause the elimination of dual-class at a pre-specified point in time & Manual Checks \\
\hline Tobin's Q & $\begin{array}{l}\text { Market value of equity plus book value of assets minus book value of equity divided by book value of assets } \\
\text { Book equity is defined as in Fama \& French (1992). Market value of equity is defined as the fiscal year end } \\
\text { close price times the number of shares outstanding as of the first fiscal year following the IPO. Book assets is } \\
\text { defined as the most recent book assets following the IPO date }\end{array}$ & Compustat; CRSP; SDC \\
\hline Transfer Sunset & $\begin{array}{l}\text { Sunsets provisions that cause any supervoting shares that are sold to entities other than a list of transferees } \\
\text { explicitly listed in the registration statement to convert to shares with one vote }\end{array}$ & Manual Checks \\
\hline VC-backed & An indicator equal to 1 if a firm was funded by a Venture Capital firm prior to the IPO & SDC \\
\hline VC Firm Age & The age of the oldest VC firm that provided financing to the firm prior to the IPO & VentureXpert \\
\hline VC Firm Size & $\begin{array}{l}\text { The total amount of funds raised by the largest VC firm (in } \$ \text { millions) that provided financing to the firm prior } \\
\text { to the IPO }\end{array}$ & VentureXpert \\
\hline VC Firms & The number of VC firms that provided financing to the firm prior to the IPO & VentureXpert \\
\hline VC Ind. Financing & $\begin{array}{l}\text { The total amount of late-stage venture capital financing provided to firms in the industry based on two-digit } \\
\text { SIC codes }\end{array}$ & VentureXpert \\
\hline VC Rounds & The number of rounds of financing by VC firms prior to the IPO & VentureXpert \\
\hline
\end{tabular}


Table A.1

The Determinants of Controllers in Dual-Class IPOs - Univariate Specifications

\begin{tabular}{l|ccccc|ccccc}
\hline & \multicolumn{4}{|c|}{ Ind. Capital = VC Industry Financing } & \multicolumn{4}{c}{ Ind. Capital = Ind. Dry Powder } \\
\hline & Dual-Class & Founder & NF Dual & NF D\&O & Co. & Dual-Class & Founder & NF Dual & NF D\&O & Co. \\
& $(1)$ & $(2)$ & $(3)$ & $(4)$ & $(5)$ & $(6)$ & $(7)$ & $(8)$ & $(9)$ & $(10)$ \\
\hline Ind. Capital & $0.00792^{* * *}$ & $0.00629^{* * *}$ & $0.00163^{*}$ & 0.000261 & 0.000303 & $0.00142^{* * *}$ & $0.00116^{* * *}$ & 0.000256 & $0.0000890^{*}$ & 0.000154 \\
& $(5.91)$ & $(5.78)$ & $(1.67)$ & $(1.17)$ & $(0.49)$ & $(6.07)$ & $(6.96)$ & $(1.46)$ & $(1.77)$ & $(1.28)$ \\
\hline Adj. $R^{2}$ & 0.0896 & 0.0876 & 0.0341 & 0.0218 & 0.0188 & 0.0874 & 0.0853 & 0.0338 & 0.0219 & 0.0190 \\
$\mathrm{~N}$ & 5,691 & 5,691 & 5,691 & 5,691 & 5,691 & 5,691 & 5,691 & 5,691 & 5,691 & 5,691 \\
\hline
\end{tabular}

This table presents the results of a linear probability model where the dependent variable is an indicator that equals 1 if an IPO has: dual-class stock in columns (1) and (6), a founder-controlled dual-class structure in columns (2) and (7), a dual-class structure not controlled by a founder in columns (3) and (8), a dual-class structure controlled by non-founder directors and officers in columns (4) and (9), and a dual-class structure controlled by a parent or holding company in columns (5) and (10). Columns (1) through (5) use VC Industry Financing as a proxy for VC investments, while columns (6) through (10) use Industry Dry Powder. All specifications include year and two-digit SIC industry fixed effects. All variables are described in the Appendix. All standard errors are robust. ${ }^{* * *},{ }^{* *}$, and ${ }^{*}$ denote significance at the $1 \%, 5 \%$, and $10 \%$ levels. 
Table A.2

The Determinants of the Wedge Between Voting Rights and Economic Rights - Univariate Specifications

\begin{tabular}{l|ccccc|ccccc}
\hline & \multicolumn{3}{|c|}{ Ind. Capital $=$ VC Industry Financing } & \multicolumn{4}{c}{ Ind. Capital = Ind. Dry Powder } \\
\hline & Public & Founder & D\&O & NF D\&O & Co. & Public & Founder & D\&O & NF D\&O & Co. \\
& $(1)$ & $(2)$ & $(3)$ & $(4)$ & $(5)$ & $(6)$ & $(7)$ & $(8)$ & $(9)$ \\
\hline Ind. Capital & $-0.209^{* * *}$ & $0.226^{* * *}$ & $0.268^{* * *}$ & $0.0438^{* *}$ & -0.00690 & $-0.0359^{* * *}$ & $0.0327^{* * *}$ & $0.0406^{* * *}$ & $0.00977^{* * *}$ & 0.000702 \\
& $(-5.70)$ & $(5.28)$ & $(6.26)$ & $(2.41)$ & $(-0.49)$ & $(-5.73)$ & $(5.72)$ & $(6.61)$ & $(3.06)$ & $(0.24)$ \\
\hline Adj. $R^{2}$ & 0.0707 & 0.0805 & 0.0835 & 0.0133 & 0.0112 & 0.0679 & 0.0741 & 0.0764 & 0.0135 & 0.0112 \\
$\mathrm{~N}$ & 5,691 & 5,691 & 5,691 & 5,691 & 5,691 & 5,691 & 5,691 & 5,691 & 5,691 & 5,691 \\
\hline
\end{tabular}

This table presents the results of a linear regression model where the dependent variable is the size of the "Wedge" between voting and economic rights for various agents within the firm, as expressed in percentage points. The dependent variable is the wedge for public shareholders in columns (1) and (6), founders in columns (2) and (7), all directors and officers in columns (3) and (8), non-founder directors and officers in columns (4) and (9), and parent or holding company in columns (5) and (10). Columns (1) through (5) use VC Industry Financing as a proxy for VC investments, while columns (6) through (10) use Industry Dry Powder. All specifications include year and two-digit SIC industry fixed effects. All variables are described in the Appendix. All standard errors are robust. ***, **, and * denote significance at the $1 \%, 5 \%$, and $10 \%$ levels. 